\title{
Relative Sea-Level Rise and the Development of Channel-Fill and Shallow-Water Sequences on Cape Cod, Massachusetts
}

\author{
by \\ Benjamin Thomas Gutierrez \\ B.S. Environmental Geology \\ College of William and Mary, 1995.
}

Submitted in partial fulfillment of the requirements for the degree of

MASTER OF SCIENCE

at the

MASSACHUSETTS INSTITUTE OF TECHNOLOGY

and the

WOODS HOLE OCEANOGRAPHIC INSTITUTION

January, 1999

(C) 1999 Benjamin T. Gutierrez. All rights reserved.

The author hereby grants to MIT and WHOI permission to reproduce and distribute copies of this thesis document in whole or in part.

Signature of

Author

Joint Program in Oceanography

Massachusetts Institution of Technology

Woods Hole Oceanographic Institution

January 12,1999

Certified

by

David G. Aubrey

Senior Scientist, Woods Hole Oceanographic Institution Thesis Supervisor

Accepted

by

Deborah K. Smith

Chair, Joint Committee for Marine Geology and Geophysics

Massachusetts Institution of Technology

Woods Hole Oceanographic Institution 


\title{
RELATIVE SEA-LEVEL RISE AND THE DEVELOPMENT OF CHANNEL-FILL AND SHALLOW-WATER SEQUENCES ON CAPE COD, MASSACHUSETTS
}

by

\author{
Benjamin T. Gutierrez
}

Submitted to the Department of Earth, Atmospheric, and Planetary Sciences, at the Massachusetts Institute of Technology and to the Department of Marine Geology and Geophysics, at the Woods Hole Oceanographic Institution on January 14, 1999, in partial fulfillment of the requirements for the degree of Master of Science.

\begin{abstract}
Channel-fill sediments located in shallow-water off the south shore of Cape Cod, Massachusetts, provide a record of the late-Pleistocene and Holocene geological evolution in a post-glacial setting. Though conventionally difficult to sample adequately and anticipated to have low preservation potential, channel-fill sequences record in some detail differing relative sea-level and sedimentation processes. Two distinct channel-fill sequences record differing sequence stratigraphies, and hence different origins and postglacial histories. These sequences have accumulated in channels eroded into two different late-Pleistocene glacial units. The first fill-type was encountered in channels on the upper portions of the channel network in northern half of the study site. Channels in this portion of the channel system were incised into the late-Pleistocene glacial outwash substrate by spring sapping (Uchupi and Oldale, 1994). The channel-fill sequences are comprised of a transgressive systems tract composed of a consistent sequence of coastal embayment and shoreline facies that have succeeded one another in response to Holocene relative sea-level rise. As relative sea-level flooded these paleo-channels, marsh environments were established in response to rising relative sea-level. With continued sea-level rise, the marsh environments migrated farther up channel. The exposed paleo-channels continued to flood, accommodating quiet water coastal embayments, likely protected from wave action by barrier beaches located more seaward. As relative sea-level rise continued, the coastline was driven landward over regions within the paleo-channels that formerly accommodated marsh and embayment sedimentation. The landward migration of the coastline was indicated by beach and barrier facies that covered the fine grained coastal embayment sediments. With further relative sea-level rise, beach and barrier settings were eroded as the shoreface migrated farther landward and nearshore marine deposition by wave and tidal flows ensued. Sedimentary environments similar to those recorded in the channels are found in modern coastal embayments on the south shore of Cape Cod.

The second channel-fill type, which forms part of the southern and western portion of the channel network is more difficult to relate to the previously described sequence. The channels that contain fill were not adequately defined in this survey but were probably incised during the late-Pleistocene in response to ice meiting and retreat. The sediments that make up this channel-fill are composed mainly of late-Pleistocene glaciolacustrine silts and clays. Sediments that make up the Holocene transgressive systems tract are limited to the upper meter of this channel sequence. They are composed of two sand units that reflect Holocene beach and nearshore sedimentation. The absence of coastal embayment and other paralic facies from the systems tract suggests that these channels did not accommodate protected embayments or that these sediments were not well preserved during the
\end{abstract}


submergence of this region. Changes in the channel orientation or in the rate of relative sea-level rise may have contributed to this difference in sediment fill.

Thesis supervisor: Dr. David G. Aubrey

Title: Senior Scientist, Department of Geology and Geophysics 


\section{Table of Contents}

Abstract................................................................... 2

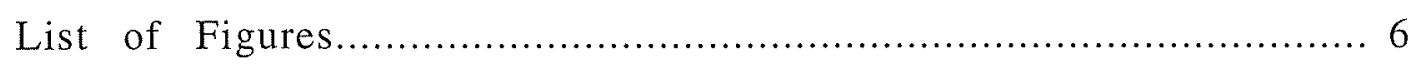

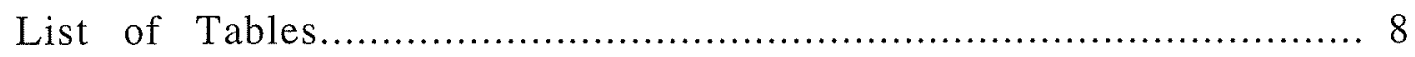

Acknowledgments............................................................ 9

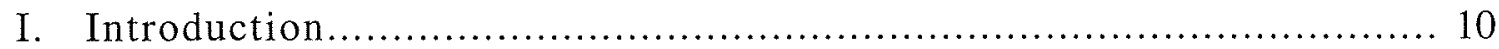

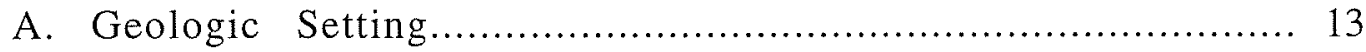

II. Methods.................................................................. 17

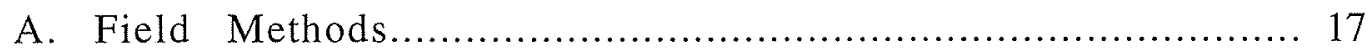

B. Laboratory Methods................................................... 18

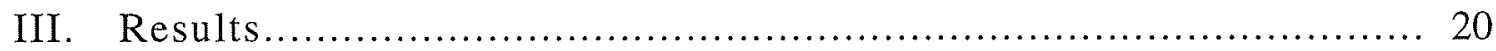

A. CHIRP Stratigraphy ........................................................ 20

1. Trunk Channel........................................................ 21

2. Channel A.......................................................... 22

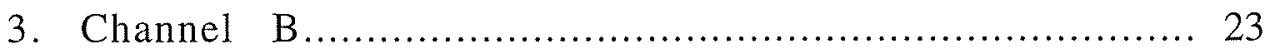

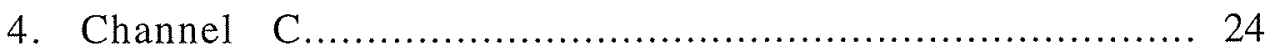

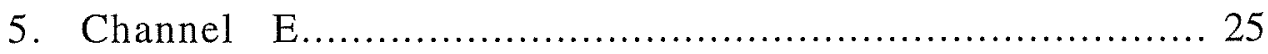

6. Small Channels....................................................... 26

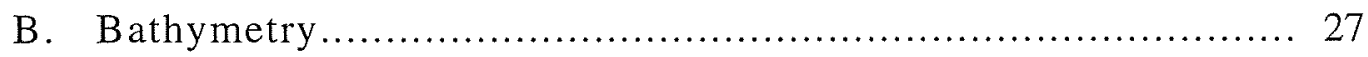

C. Channel-Fill Sediments................................................... 28

1. Sediment descriptions...................................................... 29

a. Trunk Channel................................................. 29

b. Channel A............................................. 30

c. Channel B.............................................. 32

d. Channel C.................................................... 33 


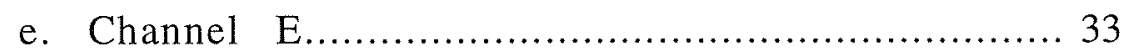

f. Small Channels................................................. 34

2. Facies Interpretations and relation to CHIRP images................... 36

a. Trunk Channel........................................... 36

i. Correlation to CHIRP Stratigraphy ...................... 38

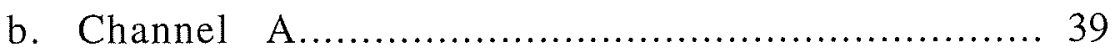

i. Correlation to CHIRP Stratigraphy ...................... 40

c. Channel B............................................... 41

i. Correlation to CHIRP Stratigraphy ...................... 42

d. Channel C............................................... 42

i. Correlation to CHIRP Stratigraphy.................... 42

e. Channel E...................................................... 43

i. Correlation to CHIRP Stratigraphy ..................... 44

f. Small Channels................................................ 44

i. Correlation to CHIRP Stratigraphy..................... 45

D. Sequence Stratigraphy of Channel-fill Deposits.................................. 46

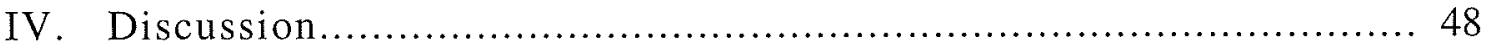

A. Transgressive Channel-Fill Sequence............................................. 49

B. Glaciolacustrine Channel Fill Sequence............................................ 54

C. Implications for the Geological Evolution of the South

Shore of Cape Cod......................................................... 55

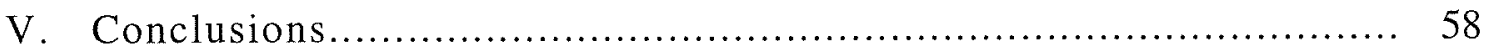

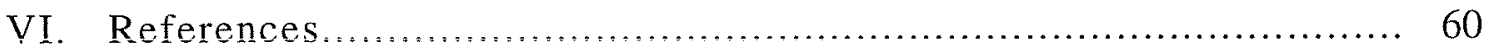

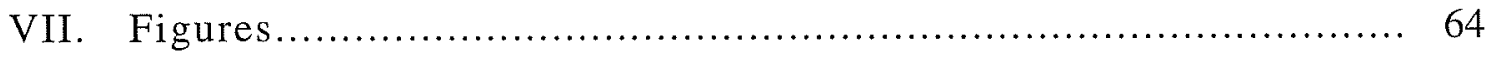

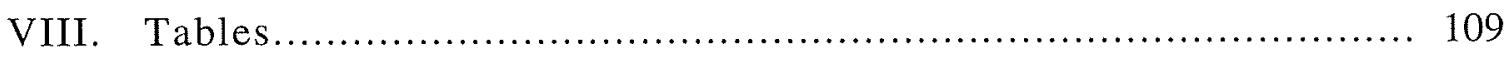




\section{List of Figures}

Figure $\quad$ Page

1. Study-site location.............................................. 65

2. Sequence stratigraphy of channelized deposits........................ 66

3. Survey track-line map.......................................... 68

4. Diagram of the ice lobes that contributed to the formation of Cape Cod....... 69

5. Geologic map of the surface deposits on upper Cape Cod.................... 70

6. Geologic map of the surface deposits on lower Cape Cod................... 71

7. Eustatic sea-level curve compiled by Milliman and Emery (1968)............ 72

8. Relative sea-level curves from southern New England compared to the Fairbanks (1989) eustatic sea-level curve............................... 73

9. Map of the offshore channel network defined based on CHIRP sub-bottom

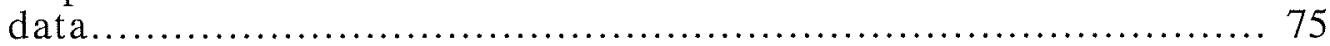

10. Interpreted CHIRP profile from the Trunk Channel....................... 76

11. CHIRP profile from survey-line 42 crossing Channel A..................... 77

12. CHIRP profiles from survey-lines $12 \mathrm{p}$ and 45 crossing Channel A........... 78

13. Interpreted CHIRP profile from survey-line 42 crossing Channel A......... 79

14. CHIRP profile from survey-line 30 crossing Channel B................... 80

15. CHIRP profile from survey-line $14 \mathrm{p}$ crossing both the Trunk Channel and Channel B........................................................ 81

16. Interpreted CHIRP profile from survey-line 30 crossing Channel B......... 82

17. Interpreted CHIRP profile from the Channel C.......................... 83

18. Interpreted CHIRP profile from the Channel E........................... 84

19. Interpreted CHIRP profiles from channels imaged in survey-lines 3 and $5 \ldots . .86$

20. Bathymetry of the study area........................................ 87

21. Map of the late-Pleistocene glacial drift surface........................... 89

22. Map of the core locations along the channel network........................ 91 
23. Cores 13 and 14 from the Trunk Channel............................. 92

24. Cores 4, 7, 10, and 17 from along Channel A.............................. 93

25. Cores 9 and 17 from across Channel A................................ 94

26. Core 16 from Channel B............................................ 95

27. Core 12 from Channel C.............................................. 96

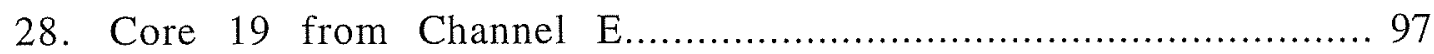

29. Cores 11 and 18 from small channels imaged in lines 3 and 5 respectively.... 98

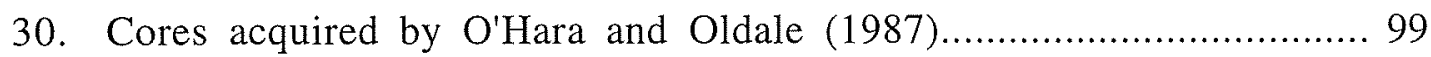

31. Interpreted sedimentary sequence filling the Trunk Channel.................. 100

32. Interpreted sedimentary sequence filling Channel A....................... 101

33. Interpreted sedimentary sequence filling Channel B........................ 102

34. Interpreted sedimentary sequence filling Channel C........................ 103

35. Interpreted sedimentary sequence filling Channel E........................ 104

36. Interpreted sedimentary sequence filling the two smaller channels.............. 105

37. Sequence stratigraphic interpretation of the channel-fill sequences defined in the Trunk Channel and Channel E....................................... 106

38. Sequence stratigraphic interpretation of the channel-fill sequences defined in Channels A, B, C, and the two smaller channels.......................... 107

39. Radiocarbon age estimates from this study compared to other studies from southeastern Massachusetts... 


\section{List of Tables}

Table Page

1. Core locations.................................................... 110

2. Ages and depths for radiocarbon samples.............................. 111

3. Total organic carbon $(\% \mathrm{C})$ and nitrogen $(\% \mathrm{~N})$ concentration for core samples......................................................... 112 


\section{Acknowledgments}

Several individuals were instrumental in guiding me through this project. I need to foremost thank my advisor, Dr. David Aubrey, for his guidance and support throughout my stay in the Joint Program. Dr. Aubrey also helped me to overcome mathphobia, a condition inherent to many descriptive geologists. Dr. Neal Driscoll has also been a significant contributor to this thesis. Dr. Driscoll provided guidance with seismic interpretation and helped shape aspects of this work. He also provided access to the Rossfelder coring system used in this project. In addition, Dr. Elazar Uchupi provided valuable advice concerning the data analysis phase of this study and the content of this paper. Dr. Robert Oldale, of the U.S. Geological Survey Woods Hole Field Center, was always willing to discuss and help me understand the glacial geology of Cape Cod. Dr. Graham Giese also provided helpful comments during the beginning of this project.

Numerous individuals were helpful in completing the field aspect of my study. Wayne Spencer and Steve O'Malley helped to organize and execute the geophysical surveys conducted in the study region. In addition, Wayne, Steve, and Quin Robertson provided assistance in the coring phase of the study. Dave Olmstead, Captain of the R/V Asterias, and Robert Lane, Captain of the F/V Dragon, operated two of the vessels that were used in the field. The efforts of graduate students and summer student fellows who were willing to roll out of bed at $4 \mathrm{a}$.m. in some cases, to get out on the water and collect data, were greatly appreciated.

In the laboratory, Larry Poppe and Alex Robertson of the U.S. Geological Survey Woods Hole Field Center guided me through the sediment grain-size analysis. Larry also guided me through the process of analyzing samples using an X-ray diffractometer and smear slides. Jessica Baker, also of the USGS, helped make the maps that were created in this study. Dr. George Voulgaris, from the University of South Carolina, helped process the sea-surface time series that was used to correct the sounding data. He also ran the tidal prediction model that was applied to the sea-surface data set.

I also need to recognize my biggest fans. I thank my family for their constant support. Lastly, thanks Erin, for being patient and understanding during this process.

While conducting this research the author was partially supported as a National Science Foundation Coastal Trainee (WHOI \# 85412900). Funding from the Andrew W. Mellon Foundation (WHOI \# 25903900) and the Woods Hole Oceanographic Institution Education Office (WHOI \# 45050) also supported this work. 


\section{Introduction}

Relative sea-level changes are commonly recorded in estuarine and lagoonal deposits. Their proximity to sea-level and low gradients make estuarine and lagoonal environments sensitive to changes in relative sea-level, recording either a landward or seaward shift of depositional patterns. In the northeastern United States and the Netherlands, marsh deposits have been used to unravel sea-level fluctuations (Redfield and Rubin, 1962; Bloom and Stuiver, 1963; Van de Plassche, 1986 and 1991; Thomas and Varekamp, 1991; Gehrels, 1994; Kiden, 1995; Van de Plassche et al., 1998). The timing of deposition in coastal embayments, while ultimately driven by changes in relative sealevel, can be complicated by variations in sediment supply, changes in coastal physiography and hydrodynamic energy (Carter et al., 1989; Jennings et al., 1993). In this study, the relative sea-level history of a study site located on the south shore of Cape Cod, Massachusetts is examined to define the relationship between sea-level history and the depositional history within nearshore environments (Fig. 1). Findings from this study help us understand how the interplay of sediment supply, nearshore processes, and physiography influence depositional processes and coastal evolution driven by changes in relative sea-level.

In a sequence stratigraphic framework, the transgressive sequence is bounded by a flooding surface which separates it from the lowstand deposits below. Beneath the lowstand deposit is an unconformity, known as the sequence boundary, which reflects a drop in base level (relative sea-level drop) that causes sub-aerial exposure and consequent erosion associated with stream rejuvenation (Fig. 2) (Van Wagoner et al., 1988). During periods of relative sea-level rise, when incised valleys formed by fluvial erosion are flooded, the boundary separating the lowstand deposits and transgressive deposits becomes complex. On the interfluves and over the upper portion of the valley wall, the contact between the lowstand surface and the transgressive sequence is unconformable.

Distinguishing the boundary between the lowstand fluvial deposits within the base of the channel, which are essentially regressive, and transgressive deposits is often difficult (Pizzuto and Rogers, 1992). The surface that reflects this transition is referred to as the transgressive surface. Above this, occurs a succession of backstepping units. These sequences eventually fill the incised valleys and are partially eroded and truncated as regional submergence ensues.

The nature of the sedimentary succession that accumulates over the fluvial unconformity depends on the type of depositional environment that exists in a particular 
coastal setting (Kraft, 1978). In the case of an embayed coastline, sequences of lagoonal or estuarine deposits may develop depending on the physiography and hydrology of the embayment (Kjerfve and Magill, 1989). As relative sea-level rises, lagoonal or estuarine environments can develop in channels, valleys, and other topographic lows that are inundated. The sediments that accumulate in these coastal embayments are progressively capped by barrier, inlet, and nearshore deposits as the relative sea-level rise continues. Typically, the unconformity, which is referred to as a ravinement surface, is cut into shoreface and beach deposits separating paralic sediments from marine shoreface and nearshore deposits (Swift, 1968; Demarest and Kraft, 1987; Nummedal and Swift, 1987). In this study, the ravinement surface is defined as the stratigraphic surface that records the first regional flooding of inter-channel areas. Along sections of coastline where coastal embayments are absent, typically along inter-channel areas, this unconformity can intersect and erode into lowstand deposits. In this case the ravinement surface will erode into and coincide with the underlying sequence boundary and transgressive surface (Fig. 2). Understanding the types of sedimentary units that accumulate above the fluvial unconformity (e.g. lagoonal or estuarine) allows us to understand and interpret the depositional history and physiography of specific coastal regions during transgression. More specifically, these stratigraphic relationships can be used to understand relative sealevel changes and depositional processes that occurred in the past.

Lagoonal and estuarine deposits commonly develop on embayed coasts in response to transgression (Kraft, 1978). Lagoonal or estuarine deposition gradually progresses landward as sea-level rises submerging the physiographic lows that intersect the shoreface. For example, such a gradual and continuous response to relative sea-level rise is reflected by a continuous along-channel record of similar depositional sequences. This type of depositional response has been noted along the coast of Delaware (Kraft, 1971; Belknap and Kraft, 1985). The along-channel depositional record can also record a non-continuous progression of facies highlighting the importance of changes in the rate of relative sea-level rise in addition to other factors in the geological evolution of coastal embayments. Examples from Nova Scotia show that local variation in sediment supply to the shoreline has resulted in irregular occurrences of lagoonal facies near local sediment sources, in this case eroding drumlins (Boyd et al., 1987).

The south shore of Cape Cod, Massachusetts provides a useful location to examine the relationship between estuarine and lagoonal sedimentation and relative sea-level changes in southern New England. O'Hara and Oldale (1987) proposed that physiographic lows in 
the glacial substrate accommodated coastal embayments as relative sea-level transgressed the Cape Cod coastline. In addition, the south shore of Cape Cod is a low energy setting relative to other shorelines on Cape Cod and southern Massachusetts. Marthas Vineyard and Nantucket Island shelter this setting from oceanic wave energy. Despite a limited tidal range between 0.5 and one meter, strong tidal currents occur in the main part of Nantucket and Vineyard Sound due to an interaction of the Gulf of Maine and Mid-Atlantic Bight tides (Redfield, 1980). Nevertheless, this site is located in a more sheltered region of Nantucket Sound where the effects of tidal scour were thought to be less important. Even though, the small tidal range has resulted in limited tidal prisms and tidal currents in coastal embayments along this shoreline. Such a low energy setting close to shore could have limited the extent of shoreface reworking due to the transgression and the degree of inlet scour as bay-mouth barriers and inlets transgressed the channel depressions increasing the preservation potential of transgressive coastal deposits. The limited tidal range on the south shore also increases the accuracy of the relative sea-level indicators. Relative sea-level studies conducted in Connecticut, Maine, and Massachusetts emphasize the use of highmarsh peats composed of Spartina patens or Distichlis spicata as sea-level indicators providing an estimate of mean high water at a particular setting (Gehrels, 1994; Van de Plassche, 1991). The smaller the tidal range the closer the estimate to mean sea-level at a given time, thus improving the accuracy of the estimation to actual relative sea-level. Lastly, the proximity of this site to the Barnstable Marsh and Vineyard Sound, the sources of well studied relative sea-level histories (Redfield and Rubin, 1962; Oldale and O'Hara, 1980; Van Heteren and Van de Plassche, 1997), enabled us to test and verify relative sealevel estimates from the south shore study site.

This study presents a newly acquired data set to determine the interplay between lagoonal and estuarine deposition in coastal embayments and the relative sea-level history on the south shore of Cape Cod, Massachusetts. During the summer of 1997, 150 kilometers of high-resolution sub-bottom profiles were collected at a study site offshore the south shore of Cape Cod between Succonesset Point and Osterville, Massachusetts (Fig. 3). Chirp sub-bottom profiles were used to identify buried channels incised into the pretransgressive glacial outwash substrate. Once these channels were defined, they were then sampled at several locations using a vibracorer. Nineteen vibracores, ranging from 0.5 to 4.5 meters were collected during the summer of 1998. Using the relative sea-level histories compiled from other locations on and near Cape Cod (Redfield and Rubin, 1962; Oldale and O'Hara, 1980; Van Heteren and Van de Plassche, 1997) and additional sea-level 
estimates obtained in this study, the relative sea-level history of the south shore of Cape Cod, Massachusetts was defined. On the basis of the relative sea-level history, the alongchannel depositional record from lagoonal and estuarine deposits that were preserved in the channel sequences were compared to the relative sea-level history. Results form this study demonstrate the sensitivity of lagoonal and estuarine deposits to relative sea-level changes. In addition to this link, we also demonstrate the importance other factors such as sediment supply fluctuations and changes in physiography in the geological evolution of coastal environments. The history presented here also contributes to the local geologic and relative sea-level history of Cape Cod and southern Massachusetts and helps to incorporate the geologic history of the south shore to other portions of Cape Cod (e.g., Barnstable Marsh).

\section{A. Geologic Setting}

Cape Cod formed in response to the melting, retreat, and re-advance of three lobes of the Laurentide Ice sheet approximately 18,000-to-20,000 B.P. (Fig. 4) (Oldale, 1982 and 1992; Uchupi et al., 1996). The three lobes of the ice sheet, the Buzzards Bay lobe, the Cape Cod Bay lobe, and the South Channel lobe deposited several outwash plains which compose most of Cape Cod (Fig. 5). The east-west trending portion of Cape Cod, known as the upper Cape, is composed of three southerly dipping (1-to-2 degrees) outwash plains deposited as the Buzzards Bay and Cape Cod Bay lobes melted and retreated to the northwest and north respectively. These three outwash plains, the Mashpee Pitted Plain, the Barnstable Plain, and the Harwich Plain, increase in age from east to west and are composed of complex deltas. They were deposited by braided meltwater streams as glacial meltwater flowed away from the ice sheet depositing sand, gravel, and cobble sized sediments (Oldale and O'Hara, 1984; Oldale, 1992). Glacial moraines form the northern and western portions of the upper Cape. These moraines formed as ice readvances bulldozed glacial outwash material into topographic highs along these portions of the Cape (Oldale, 1992). The outer arm of Cape Cod, known as the lower Cape, is also mainly composed of westward dipping outwash plains: the Eastham, Wellfleet, Highland, and Truro plains (Fig. 6). They reflect outwash deposition from the South Channel lobe of the Laurentide İce sheet, which retreated to the northeast. İce-contact deposits such as kames and collapsed outwash, which occur locally on outwash plains form local topographic highs on outwash plains.

The outwash overlies local accumulations of glacial till and glacial lake deposits (Uchupi et al., 1996). In general, glaciolacustrine deposits are limited to Nantucket Sound 
and portions of Cape Cod Bay. Glaciolacustrine deposits rest over isolated occurrences of glacial till and remnants of incised Cretaceous Coastal Plain deposits. The glaciolacustrine units were deposited in proglacial lakes which developed in depressions south of the ice sheet as it retreated to the north. Coastal Plain deposits are absent under the northern half of the upper Cape but then thicken to the south into Nantucket Sound where they are capped by glacial units. Isolated occurrences of coastal plain deposits may also be present under the lower Cape. Coastal Plain and glacial units rest over Mesozoic basement which varies in depth from 50 -to-150 meters.

The geological development of the south shore of Cape Cod and Nantucket Sound are not well defined. This region remained sub-aerially exposed until approximately 9,500 B.P when relative sea-levels reached 30 meters below present. It is assumed that as relative sea-level progressed into this region, channels defined by O'Hara and Oldale (1987) were the first to become inundated (Uchupi et al., 1996). Sampling in a few of these channels, by O'Hara and Oldale (1987), confirmed the presence of fluvial estuarine channel fill sequences. A seismic investigation in Nantucket and Vineyard Sounds showed that post-glacial deposits in this region are confined to a thin layer of sediment overlying an erosional surface (O'Hara and Oldale, 1987). In many places these seismic records were unable to resolve deposits above this surface. O'Hara and Oldale (1987) also identified many sand shoals located throughout the Nantucket and Vineyard Sounds. These features were interpreted as marine beach and bar deposits. Although the age and origin of these features are not well constrained, most of the highs were thought to be post-transgressive accumulations of sand deposited by tidal currents.

Three glacial features dominate the morphology of the present coastline on the south shore of Cape Cod. One of these is a series of linear, north-south trending valleys that are located in the outwash plains along the south shore. Initially, it was thought that these channels were formed by meltwater that flowed over the exposed outwash plains (Woodworth and Wigglesworth, 1934; Strahler, 1966). More recently it has been suggested that these channels have resulted from groundwater sapping through the outwash plain during deglaciation when a proglacial lake existed in the present location of Cape Cod Bay (Uchupi and Oldale, 1994; Driscoll and Uchupi, 1997). Today these valleys form linear north-south trending embayments, particularly in the western portion of Cape Cod along Vineyard and Nantucket Sound. It is possible that these channels continue to the south beyond the shore face into Nantucket and Vineyard Sound and connect to channels defined offshore by O'Hara and Oldale (1987). However, their data does not allow the 
connection of buried offshore channels with three coastal embayments in this region. A fluvial system, which was mapped throughout Nantucket and Vineyard Sounds, is believed to have been created by surface drainage of spring sapping run-off down the free surface prior to the Holocene transgression (Uchupi, et al., 1996). In addition, glacial ice-contact deposits located along the shoreline may have formed intermittent sediment sources as they were eroded and reworked as relative sea-level transgressed. On the present shoreline, three such deposits exist (Falmouth Heights, Popponesset, Point Gammon). Changes in coastal orientation occur locally around two of these deposits. In addition, each of these features has undergone some degree of stabilization, which retards their erosion. The presence of these features on former Cape Cod shoreline positions may have had a significant effect on local sediment fluctuations influencing the depositional history of nearby embayments. Kettle depressions and kettle ponds may have also influenced the depositional record offshore of the present coast. It has been suggested that kettle depressions and kettle ponds that occur on the outwash plains of Cape Cod contribute to the formation of small coastal lagoons along portions of the shoreline as they are encountered by the transgressing shoreline (Fitzgerald, 1993; Uchupi et al., 1996).

In the last 36,000 years relative sea-levels have fluctuated as much as 130 meters (Emery and Uchupi, 1984). Work in the Atlantic Ocean (Emery and Uchupi, 1984) has shown that relative sea-level was near its present elevation as far back as 35,000 B.P. during a Pleistocene interglacial (Fig. 7). Recent estimates argue that the last glacial maximum and sea-level lowstand occurred between 18,000 and 21,000 B.P. due to increased ice volume in response to ice build-up (reviewed in Uchupi et al., 1996). Eustatic sea-levels have risen approximately 121 meters since the last glacial maximum (Fairbanks, 1989). Because of glacial unloading, New England relative sea-level history has differed from eustatic sea-level history (e.g., Fairbanks, 1989; Bard et al., (1990)) (Fig. 8). Differences between eustatic and New England sea-levels were accentuated to the north where ice loading was greater, coinciding with maximum ice thickness (Oldale, 1985, 1993; Uchupi et al., 1996). In central Maine, relative sea-level was as much as 130 meters above present whereas in northeastern Massachusetts and Boston relative sea-level was 33 and 18 meters respectively above present at the post-glacial highstand. The timing of this highstand occurred at each of these locations approximately 14,000 B.P. (Uchupi et al., 1996). Sub-aerial portions of Cape Cod show no signs of this highstand (Uchupi et al., 1996). At this time, eustatic sea-level rise was slower than crustal uplift due to glacial rebound. Relative sea-level in New England fell until approximately 12,000 B.P. at the 
post-glacial lowstand. Since 12,000 B.P. relative sea-level has been rising in New England and more closely follows the eustatic sea-level trend. Both tide-gauge studies and relative sea-level curves based on high-resolution marsh studies show that sea-level trends differ between New England and eustatic sea-level estimates (Emery and Aubrey, 1991). This difference might be due to lasting effects of glacial unloading and regional neotectonics (Emery and Aubrey, 1991; Gehrels and Belknap, 1993; Uchupi et al., 1996).

Since the post-glacial lowstand approximately, 12,000 years B.P., relative sea-level in southern New England has been rising. Between 9,500 and 6,000 years B.P., it has been estimated that relative sea-level rose from 40 meters to 10 meters below present at an average rate of $6 \mathrm{~m} / 1000$ years in southern Massachusetts (Uchupi et al., 1996). By 6,000 B.P., the rate of sea-level rise diminished to $2 \mathrm{~m} / 1000$ years approaching its present elevation by 1,000 years B.P. Emery and Aubrey (1991) suggested that this change in the rate of sea-level rise resulted from the decrease in the rate of meltwater input from ice retreat and melting. Others suggest that this change may be related to the final compensation of a peripheral bulge resulting from glacial loading on the earth's surface (Uchupi et al., 1996). A review of relative sea-level studies in New England showed evidence of a change in the rate of relative sea-level occurring approximately 2,500 years B.P. in southern New England (Oldale, 1985). Between 8,000 and 2,500 B.P., the rate of relative sea-level rise may have been $3 \mathrm{~m} / 1000$ years, and by 2,500 years B.P. this rate decreased to $1 \mathrm{~m} / 1000$ years. A few researchers have suggested that these changes in the rate of relative sea-level rise might coincide with the onset of marsh development which were able to exist due to decreased rates of submergence (Bloom and Stuiver, 1963; Rampino and Sanders, 1980b; Uchupi et al., 1996).

A relative sea-level study in Barnstable Marsh on Cape Cod (Redfield and Rubin, 1962), has constrained the relative sea-level history on Cape Cod during the past 4,000 years. This study was based mainly on radiocarbon dates of high-marsh peats deposited as Barnstable marsh developed during this time period. Relative sea-level estimates from this curve show that between 3,700 B.P. and 2,100 B.P., relative sea-level rose at a rate of $3 \mathrm{~m} / 1000$ years. Between 2,100 and present day, relative sea-level has been rising at a rate of $1 \mathrm{~m} / 1000$ years according to this study. A recent investigation of the depositional history of Barnstable marsh verified the interpretation of this sea-level curve (Van Heteren and Van de Plassche, 1997). Present day tide-gauge studies have determined that relative sea-level is rising at a rate of two millimeters per year in southern New England with this rate increasing to three millimeters per year in Maine (Gehrels, Belknap and Kelley, 1996; 
Uchupi et al., 1996). Eustatic sea-level rise accounts for one-to-two millimeters per year of this rate (Uchupi et al., 1996). The other portion of this rate is believed to be associated with lasting effects of glacial loading and unloading on the lithosphere and neotectonics.

\section{Methods}

\section{A. Field Methods}

During the summer of 1997, 150 kilometers of high-resolution sub-bottom profiles and bathymetric soundings were collected off the south shore of Cape Cod between Succonesset Point and Osterville, Massachusetts. Sub-bottom data were collected using an Edgetech SB-216 CHIRP sub-bottom profiler operating at 2-to-10 kHz. At this frequency range, the profiler is capable of penetrating 8 meters in sand with $18 \mathrm{~cm}$ resolution $\left(1 / \Delta \mathrm{f}^{*} \mathrm{~V}\right)$ (Edgetech, 1997). Sub-bottom data were recorded on digital computer tape. Hard copy print outs of the profiles were also generated. At the same time, bathymetric soundings were acquired using an Odom Echotrac echosounder operating at $200 \mathrm{kHz}$. Soundings were collected and logged by computer every 1.8 seconds. These data were corrected for tidal variations during the survey and the depth of the transducer. A tide gauge manufactured at the Woods Hole Oceanographic Institution was used to determine sea-surface elevations during the survey so that depth soundings could be referenced to mean sea-level.

The CHIRP profiler and the echosounder were towed at a speed of 4-5 knots from either the 24-foot Woods Hole Oceanographic Institution coastal research vessel R/V Mytilus, or a 32-foot fishing vessel, the F/V Dragon. Forty-six dip-lines, oriented northwest-southeast, nominally spaced 182 meters apart ranging from 1-to-3 kilometers in length. Six 10-kilometer long strike-lines, spaced 460 meters apart, were also collected. The orientation of the dip-lines was designed to constrain former shoreline positions; the coarse strike-line spacing served mainly to correlate dip-lines in the survey area and examine channel morphology. The two-meter towing depth of the CHIRP profiler limited the shoreward extent of the survey. The instrument was towed at this depth in order to avoid interference from the survey-vessel wake and propeller noise while attempting to maximize the imaging capability of the system in shallow water.

Additional CHIRP data were collected in July of 1997 and November of 1998. These additional surveys on the Woods Hole Oceanographic Institution's R/V Asterias 
retraced a few of the shore-parallel strike lines using CHIRP profilers capable of greater acoustic penetration without significant loss of vertical resolution. In July 1997, three of the strike lines were re-surveyed using an Edge-tech SB-0512 sub-bottom profiler operating at a $1.5-7.5 \mathrm{kHz}$ frequency. In addition, another survey in November of 1998 was conducted using a the new Woods Hole Oceanographic Institution CHIRP profiler using a $1-15 \mathrm{kHz}$ pulse frequency. These systems were reused to retrace several survey lines in order to clarify the relationship between several deeper acoustic units that were poorly imaged using the SB-216 system.

During the summer of 1998, 19 vibracores were collected using a Rossfelder P-5 Vibracorer (Table 1). The system was operated aboard the Woods Hole Oceanographic Institution's R/V Asterias. The Rossfelder P-5 corer was operated using 4.87 meter (16 feet) steel core barrel with cellulose acetyl buterate liners (CAB). Core lengths varied between 0.5 and 4.7 meters. Compaction was difficult to determine as attempts to measure core-barrel penetration were ineffective. Vibracore sampling was focused on the channel network defined from the sub-bottom data in order to confirm the presence of, and to sample, channel-fill sequences in these areas. Attempts were also made to sample the interchannel regions imaged with the CHIRP equipment, but penetration is these regions was limited. Thirteen of the nineteen vibracores that were obtained were included in this study. Six of the nineteen vibracores were either significantly disturbed during coring, or they were shorter cores acquired at sites where longer cores were eventually obtained.

\section{B. Laboratory Methods}

Sounding data were processed using a hydrographic-survey software package. These data were tide-corrected using a harmonic analysis model (Foreman, 1977) based on tide gauge data that were collected at the study site. Using the synthetic tide curve created for the time interval over which the survey occurred, soundings were referenced to the mean sea-surface elevation defined during this period. Tide-corrected soundings were filtered and plotted on a base map of the survey area. A bathymetric chart of the survey area was then created from these depth soundings.

CHIRP sub-bottom data were printed using a thermal printer. The hard copy records were analyzed and interpreted. Using these records, channels were identified and their positions were logged and plotted on a base map of the survey area. Plotted channel positions were then linked from line to line. In addition to channel position, similarities in the channel morphology and CHIRP stratigraphy were used as supporting criteria for 
linking channels to those on adjacent survey lines. Where channels were poorly defined and uncertainties existed about channel paths, a map from O'Hara and Oldale (1987) was used to guide interpretation and mapping.

Cores were split, photographed, and described. Each sedimentary unit defined in the cores was then sampled for grain size analyses at the sediment laboratory at the U.S. Geological Survey Woods Hole Field Center. The coarse fraction $(>62 \mu)$ was analyzed by mechanical sieving and the fine fraction was analyzed using a Coulter Counter. Results from these analyses were entered into a software program that computed statistical distributions from each sample. These results plus smear slides of the silt and clay fraction enabled the precise description and correlation of different sedimentary environments represented in the core samples. Fossils that were present in the cores were sampled and described. Marine bivalves that were articulated and in living position in the cores were radiocarbon dated. It was thought that these specimens were deposited in-place. Peat layers were also sampled in order to identify plant fragments and microfossils contained in the samples. Plant fragments representing high-marsh peats composed of Spartina patens or Distichlis spicata are valuable sea-level indicators (Redfield and Rubin, 1962; Gehrels, 1994). The peats that were sampled in this study consisted of plant fragments that were too fine to identify visually. Dates were obtained from peat samples and bivalves to define the position and timing of different paleo-environments along these channels.

Carbon-bearing samples were sent to the Woods Hole Oceanographic AMS facility or Beta Analytic Inc. for radiocarbon dating (Table 2). Samples consisting of peat, wood, and shell material were dated. The peat and wood samples were treated several times with heated sodium hydroxide in order to remove humic and fulvic acids that contaminate organic carbon samples (Van de Plassche, 1986). Stable carbon isotope abundances, which are provided with $\mathrm{C}-14$ age estimates, were also determined. These measurements were sampled only from the organic carbon samples. C-13/C-12 abundances are useful in determining or confirming the marine or freshwater origin of marsh peats (Chmura et al., 1987).

Sixteen samples were analyzed for total organic carbon and nitrogen concentrations using a CHN analyzer at the Woods Hole Oceanographic Institution (Table 3). These measurements were taken from silt samples obtained from several cores in order to assess the relationship of the silt units to one another. These data were also useful in conjunction with the stable carbon isotope data to identify paleo-environments recorded in these deposits. 


\section{Results}

High-resolution CHIRP sub-bottom profiles defined a buried channel network and the channel-fill sequences that fill them, in the region offshore of Popponesset, Massachusetts. Several sites were examined along this network in order to explore the along-channel variations in the channel-fill sequences and how they relate to the relative sea-level history of this region. Using portions of the CHIRP record that were adequately defined and sampled, the seismic stratigraphy of several parts of this channel system were evaluated. It was difficult to assess the channel-fill stratigraphy based on CHIRP records alone. For this reason, sedimentary sequences that have accumulated in the channels were also defined based on the channel-fill stratigraphy sampled with vibracores. The interpretation of the channel-fill sequences helps to understand the sequence architecture of the deposits that have accumulated in these channels. This improved the understanding of how the late-Pleistocene glacial landscape has influenced the geological evolution of the coastline in response to relative sea-level rise.

\section{A. CHIRP Stratigraphy}

CHIRP data collected in this study in conjunction with maps compiled in a previous investigation (O'Hara and Oldale, 1987) defined a dendritic channel network in the region offshore of Popponesset, Massachusetts. The channel network consisted of four large southerly-trending channels that extended offshore to merge with a trunk channel that trends from east-to-west (Fig. 9). Each of these feeder channels was in-turn fed by smaller tributaries that merged into the four larger channels. Smaller tributary channels formed the northern limit to two of the four main feeder channels (Channels B and C). The other two feeder channels extended farther toward the present shoreline beyond the limit of the survey (Channels $\mathrm{A}$ and $\mathrm{E}$ ). The seismic stratigraphy of the channels varied from channel-tochannel. Three channel types are discussed:
a). The east-west trending trunk channel
b). The four feeder tributaries to the trunk channel
c). Two smaller tributary channels 


\section{Trunk Channel}

CHIRP records defined a large east-west trending Trunk Channel that formed the core of the channel network in this region. This feature was evident in the western half of the study region between survey lines 14 and 24, where position of the Trunk Channel coincided with a channel-parallel topographic low. This was the only channelized feature that was expressed in the bathymetry of the study area. Toward the east, beyond survey line 24, this channel was not well-defined due to the thickness of overlying deposits that limited acoustic penetration. The Trunk Channel path to the east was extended using a map defining the structure of the late-Pleistocene glacial drift surface by O'Hara and Oldale (1987). CHIRP data indicates that the feature is as much as 430 meters wide and has symmetric cross-sections with channel-wall slopes of $1 / 25$. The base of the channel sequence, where it is imaged, is characterized by an irregular seismic reflector that occurs approximately 21 meters below present mean sea-level. A CHIRP profile from survey line 17 demonstrated that this feature is composed of more than one channelized depression (Fig 10). Limited acoustic penetration caused by thicker overlying accumulations of sediment prevented this observation in other CHIRP profiles of the Trunk Channel. A shore-parallel survey line across the Trunk Channel suggests that the it may meander. Due to difficulties imaging the Trunk Channel in the shore-normal survey lines, it was difficult to determine its true sinuosity.

The internal stratigraphy of the Trunk Channel is apparent from several CHIRP profiles. Orthogonal survey lines showed that the floor of the channel formed a symmetrical U-shaped cross-section (Fig. 10). The base of the channel unconformity was mainly flat-lying with several irregularities. A basal transparent unit reaching five-to-seven meters in acoustic thickness overlies the channel unconformity. This unit contains one Ushaped internal reflector. A flat-lying reflector across the channel truncates the top of the transparent unit. Above this, three layered reflectors overlie the top of the channel sequence. A thin tabular unit, 0.75 meters in acoustic thickness, covers this reflector in the center of the CHIRP sequence. This unit is in turn overlain by two layered units, which, although poorly defined, appears to cover the top of the channel sequence. The upper boundary of the upper unit forms an irregular seafioor, due to the presence of asymmetric sand waves. 


\section{Channel A}

Channel A, which occurs along the eastern portion of the study site, is the most clearly defined channel feature in the study area. This channel trends southward and curves slightly to the west where it is less well resolved in the CHIRP record. The width of the feature ranges between approximately 260 and 300 meters and consists of three-to-four $V$ shaped lows. The middle two lows are the most consistently imaged by the CHIRP sonar whereas two outer lows within the feature are less distinct. The slopes of the channel walls vary from approximately $1 / 4$ to $1 / 38$. Channel depths reach 13 meters below present mean sea-level in the northern parts of Channel A and 16.5 meters at its southern positions. In many cases, it is difficult to assess the actual channel base due to interference with the first acoustic multiple. Several smaller channels also drain into Channel A. These smaller features are not well-defined beyond 200 meters of the channel. Nonetheless, their occurrence appears to form a dendritic pattern. Toward the southern portion of Channel A, the image quality of the CHIRP profiles decays. Its continuation to the southwest was extended using the results of O'Hara and Oldale (1987). A large sand body limited the acoustic penetration of the CHIRP signal resulting in poor resolution of the channel. The position of this feature in the presented channel network and in O'Hara and Oldale (1987) indicates that Channel A forms the northeastern extension of the Trunk Channel.

CHIRP records provided images of the sedimentary sequences that filled Channel A. Each of these channels was identified by a $\mathrm{U}$ or $\mathrm{V}$ shaped reflective surface which forms the basal channel unconformity (Fig. 11). The depth to the high-amplitude basal reflector in these channels ranges between 13 to 16.5 meters below present mean sea-level. Reflectors in deeper portions of the larger channels are difficult map as they coincide with the first acoustic multiple. It was difficult to determine if the flat lying reflectors within some of the channels are the basal channel unconformity or reflectors within the lower channel sequence. Two profiles from Channel A show that the high-amplitude reflector in the lower portion of the channel may not be the channel base (Fig. 12). These profiles demonstrate that the actual channel floor may coincide with a weaker reflector just below the basal high-amplitude reflector. For most of the profiles, the first acoustic multiple towards the base of Channel A images made this distinction diffficult.

In most of the seismic lines defining Channel $\mathrm{A}$, the transparent units that overlie the channel unconformity are capped by a high-amplitude, scattered reflector (Fig. 13). This reflector ranges from 0.3 to 1.5 meters thick. However, this high-amplitude reflection is not evident in all the images of Channel A. Where it does occur, the channel-fill 
sequence is capped by a semi-transparent unit. Where this upper unit thins, it is at times indistinguishable from the seafloor reflector in the CHIRP profiles. Where the semitransparent unit is distinguishable in the channel divides, its flat-lying lower boundary is interpreted to be the ravinement surface, an erosional surface caused by the shoreward erosion, re-deposition, and translation of the shoreface during transgression (Swift, 1968; Demarest and Kraft, 1987; and Nummedal and Swift, 1987). CHIRP profiles show that the flat-lying reflector, which was interpreted as the marine unconformity or ravinement surface, truncates the upper limits of the channel unconformity. This surface was difficult to trace over the channel sequences but was more easily distinguished in the channel divides. Above this surface, the surficial transparent unit was thought to represent modern seafloor deposits. This unit reached a meter in thickness in some regions near or over the channels.

\section{Channel B}

Channel B occurs on the eastern half of the study site and follows a trend similar to Channel A. The width of Channel B ranges from 110 to 300 meters, and its wall slopes vary between $1 / 4$ and $1 / 30$. The depth of the lower channel reflector ranges from 11 meters below present mean sea-level near the northern most part of Channel $B$ to almost 16 meters at its southern limit. Like channel $\mathrm{A}$, it was difficult to determine the actual base of the channel sequence due to interference from the first acoustic multiple in the CHIRP record (Fig. 14). Where the first acoustic multiple does not coincide with the base of the channel, it is still difficult to determine whether the high-amplitude basal reflector is the channel base or just a strong lower reflector within the channel sequence.

The width of Channel B increases to the north where two channels appear to merge to form one single channel. Starting at line 30, CHIRP profiles to the east indicate that Channel B was fed by the two parallel channels that merged to the north. Northeast of CHIRP line 32, it was difficult to map the extent of these channels on the basis of CHIRP data. CHIRP images on adjacent survey lines failed to resolve the channels. Additional data from O'Hara and Oldale (1987) were also insufficient.

Plotted positions of Channel B suggest that the southern reaches of the channel merged with the Trunk Channel, yet CHIRP records show that Channel B and the Trunk Channel are embedded in different acoustic units. In CHIRP lines defining the southern portions of Channel B the base of the channel was traced 14 meters below present mean sea-level (Fig. 15). The reflector that separates the acoustic unit that contains Channel B 
from the unit that contains the Trunk Channel occurs two meters deeper in the section. The position of the Trunk Channel at this location was inferred from O'Hara and Oldale (1987) as CHIRP records did not image the Trunk Channel at this site. Where the base of the Trunk Channel is defined it occurs 19 to 21 meters below present mean sea-level. Thus, the southern portions of Channel B appears to be stratigraphically higher than the Trunk Channel in this region.

CHIRP profiles across Channel B show a flat-bottom U-shaped reflector that represented the profile of the channels. Like channel $\mathrm{A}$, it is unclear whether or not the flatlying, high-amplitude reflective surface at the bottom of the channels is actually the base of the channel or just a lower reflector in the channel-fill sequence caused by a change in sediment texture or composition. This reflector reached a meter in acoustic thickness in some of the channel profiles. Above this reflector there is a transparent unit, which is capped by a strong reflector. In a few channels, this unit is semi-transparent with several partially layered, discontinuous reflectors. In most of these channels it is difficult to trace accurately the reflector that bounds the upper portions of the transparent fill across the channel profile. As for Channel A, a few CHIRP profiles of the Channel B fill sequences suggested the presence of additional reflective surfaces above the transparent channel-fill unit (Fig. 16). Nonetheless, the definition of these reflectors in these channels is limited in other channel profiles. Although no reflectors distinctly truncate the upper portions of the channel, the ravinement surface is inferred in the CHIRP records by the truncation of the upper channel walls. Towards the southwestern portions of Channel B, CHIRP profiles show a surficial transparent unit lying above the top of the channel sequence. The base of this unit is not clearly defined. The top of this unit lies at the seafloor. The morphology of its upper boundary indicated the presence of sand waves suggesting that this is a modern sedimentary unit. Profiles across the northeastern portion of Channel B also showed a surficial semi-transparent unit mantling the channel-fill sequence. Here the top of this unit that formed the seafloor is a smooth tabular body as opposed to the southeastern portions of this channel where sand waves accentuate the roughness of the seafloor.

\section{Channel $C$}

This portion of the offshore channel network is composed of two parallel features which form the northern extensions of a channel that parallels Channels A and B. CHIRP lines defining the southwestern portions of this channel are not clear. Data from O'Hara and Oldale (1987) also provided little guidance in defining the stratigraphy of these 
channels. Both the present data set and the former study indicated that Channel $\mathrm{C}$ merged into the Trunk Channel to the south. Even though the images of these channels are difficult to interpret, the V-shaped channel reflectors were sufficient to map the presence of and determine the dimensions of these features (Fig. 17). Channel walls vary in slope from 1/4-to-1/15. The combined width of the two parallel channels reached 160 meters in the northern part of Channel $\mathrm{C}$ that is well-defined. To the south, where Channel $\mathrm{C}$ is not well-imaged, channel widths reach 300 meters. Channel depths to the north appear to reach 10.5-to-11 meters below present mean sea-level, yet the actual base of these channels is difficult to accurately define. Poorly resolved CHIRP records indicate that channel depths may extend 15 meters below present means sea-level in the southern reaches of Channel C. Shallower high-amplitude reflectors appear to attenuate the quality of CHIRP reflections in these channels. In a few images, high-amplitude layers indicate acoustic distortion caused by biogenic gas. Poorly defined CHIRP records show that the channel depths may extend 15 meters below present mean sea-level in the southern reaches of Channel C.

The internal seismic stratigraphy of two side-by-side channels that merge to form Channel $\mathrm{C}$ is not clear enough to define fully the extent of the feature (Fig. 17). The presence of scattered high-amplitude reflectors between 1.5 and 2 meters below the seafloor ( 8.5 to 9 meters below present mean sea-level) limit the resolution of these channel-fill sequences in the sonar data. At most, it appears that the channelized feature extends four-to-five meters beneath the seafloor. The upper portions of the channel images are also poorly defined, yet faint structures are evident. The channel-fill appears to consist of two-to-three layered acoustic units, which connect to faintly defined flat-lying reflectors on the interfluves. In one of the channels, this reflector merges with a flat-lying reflector that covers the upper portions of the channel-fill. This stratal relationship was interpreted as a ravinement unconformity that truncated upper portions of a transgressive sequence on channels and merged with the pre-transgressive substrate over the inter-channel highs.

\section{Channel E}

Channel E, which also formed a tributary of the Trunk Channel, differs from the two other tributaries. CHIRP profiles were unable to define fully the extent of this feature. Mapped channel positions show that the feature is as much as 450-to-700 meters wide consisting of two buried topographic lows; one large buried valley and an adjacent irregular topographic low (Fig. 18). The shoreward wall of Channel $\mathrm{E}$ is not imaged in the CHIRP 
record. The channel wall exists either too far shoreward and not imaged in the survey or was not imaged due to the penetration limitations of the CHIRP profiler. The depth of the channel low reaches more than 19 meters below present mean sea-level. Due to interference with the first acoustic multiple and limited acoustic penetration, CHIRP profiles do not always resolve the channel floor. The size, morphology, and orientation of Channel $\mathrm{E}$ in relation to other channelized features in this study area suggests that other processes formed this channel. The connection between Channel $\mathrm{E}$ and the Trunk Channel is not clear based on CHIRP data despite the suggested link in O'Hara and Oldale (1987).

CHIRP images of Channel $E$ differ from images of other feeder channels that form tributaries of the Trunk Channel. Profiles from Channel E show that an irregular reflector denotes the valley floor (Fig. 18). This reflector is irregular and exceeds a meter in acoustic thickness. The low appeared to be filled with a relatively thick unit that appears transparent in places having several well defined reflectors that follow the valley profile. The upper portions of this unit are truncated by a generally flat-lying reflector which could coincide with the ravinement surface. This flat-lying reflector forms the base of a surficial unit whose surface topography is accentuated by sand waves on the seafloor.

\section{Small Channels}

Two channels, profiles from survey lines three and five, imaged near the western edge of the Popponesset study site are also included in this analysis. These channels could only be mapped over a small portion of the study area. Despite their close proximity to Channel E, they have no apparent connection to the larger feature. The base of Channel E reaches 19 or more meters below present mean sea-level, whereas these channels reach 14 meters below present mean sea-level at most in close proximity to Channel E. This difference in elevation and channel size is difficult to explain between the two features based on CHIRP images alone.

The top portions of the channels are clearly visible, but the bottom portions of the channel fill are clouded by gas reflections in the CHIRP record (Fig. 19). Upper portions of the channel structure, which are more clearly imaged, indicate that the channels have a $\mathrm{V}$-shaped cross-section. Below the strong gas reflections, it is difficult to assess the actual depth of the channels. At most, the bases of the channels reach between 12-to-14 meters below mean sea-level. Channel widths at this site are approximately 150 meters and channel slopes range between 1/10-to-1/20. 
Although CHIRP records clearly illustrated the presence of channels at these sites, the actual stratigraphy at these sites is difficult to determine from these images (Fig. 19). Channels are denoted by distinct $V$-shaped reflectors that were filled with a mid-channel, high-amplitude convex-up reflector. The high-amplitude reflectors in the middle of the channel, which are thought to be caused by biogenic gas, limit acoustic penetration of the lower channel sequence. A poorly defined semi-transparent unit occupied the upper portion of the channel sequence. The definition of the upper portion of the channel sequence is not clear.

\section{Summary}

CHIRP images acquired from the study site define a channel network that has been preserved offshore of the present coastline. Data from this study are sufficient to define five portions of this channel network and two additional small channels. The relationship of these channels to one another, based on channel position, trend, and stratigraphy, is inferred from data in the present study and a former investigation (O'Hara and Oldale, 1987). Differing CHIRP image quality of the channels defined here make it difficult to relate each part of the channel network directly. Poor image quality toward the southern portions of Channels $\mathrm{A}$ and $\mathrm{C}$ limits the certainty with which these channels can be related to the Trunk Channel. Likewise, unclear CHIRP images in the region between Channel $\mathrm{E}$ and the Trunk Channel do not definitively identify a direct connection between the channels despite the connection inferred from O'Hara and Oldale (1987). Two smaller channels that occurred to the west of Channel $\mathrm{E}$ could not be directly correlated to the larger feature due to contrasts in size, depth, and CHIRP images. Lastly, CHIRP images show that Channel $\mathrm{B}$, which bears a similar CHIRP stratigraphy to Channel A, is superimposed over top of the trunk channel raising doubt concerning a direct relationship between the two features.

\section{B. Bathymetry}

Contoured sounding data show that the seafloor topography varies across the study region (Fig. 20). A broad, low-gradient platform occupies the northern half of the region. In the western portions of the platform, northwest-southeast trending sand waves create irregularities in the seafloor. To the east, the surface of the platform is more subdued consisting of several gently sloping, shore parallel shoals. Shoals on the eastern half of the study area become more extreme to the south. A large east-west trending low, bordered to 
the south by a large sinuous shoal, occupies the southern half of the study region. The low reaches a maximum depth of 17 meters below present mean sea-level, and the shoal peaks in several locations at less than 3 meters below present mean sea-level. To the east, the topography of the large shoal is more subdued than in the west.

The large east-west trending low is the only topographic feature that coincides with any portion of the channel network defined from the CHIRP data. A structure contour map of Nantucket Sound from O'Hara and Oldale (1987) shows that this depression forms a large low in late-Pleistocene glacial drift surface that continues to the southeast in spite of the large shoal that appeared to truncate its path in the contoured bathymetry (Fig. 21). Despite the truncation of the large low that coincides with the Trunk Channel, the other portions of the shoal appear to form a high in the late-Pleistocene glacial drift surface. CHIRP data collected in the present investigation fail to provide images that delineated the stratigraphy of these shoals. None of the other channels that define the channel network appeared to correlate to the seafloor topography. The subtle shoals in the northwestern quarter of the study area cross the channels in several areas, and in some cases, coincide with areas where these channels are poorly defined in CHIRP profiles (See I.CHIRP Stratigraphy: Channel A).

Where the low-gradient platform in the northern half of the study area is covered with sand waves, CHIRP profiles reveal few channel images that can be mapped and connected to clearly define a channel. A thick sand cover between 1-to-3 meters thick, may have impeded the acoustic penetration of the CHIRP profiler in this region. Data collected by O'Hara and Oldale (1987), using a seismic system capable of greater acoustic penetration, showed that two additional channels were present in this region. Differences in navigational accuracy and the scarcity of CHIRP profiles that were able to image the channels in this area prevent the direct connection of the two data sets.

\section{Channel-fill sediments}

Vibracores penetrated core sites that coincided with CHIRP survey locations across each of the previously described channel-fill sequences. Thirteen cores were used to describe three channel-fili sequences present in the channel network that was imaged off of the south shore of Cape Cod (Fig. 22). Two of these sequences are transgressive sequences that accumulated in formerly exposed channels, which were landward of the shoreface during periods of lower sea-level. The other channel-fill sequence are related to processes associated with glacial melting. 


\section{Description of Channel Sediments}

\section{a. Trunk Channel}

Two cores were used to define the channel-fill sequence in the Trunk Channel that runs through the center of the study area (Fig. 23). The cores were acquired at sites coinciding with survey line 17. At the site of this profile, the sand waves that cover this site were the thinnest of any of the adjacent profiles of this feature. In addition, the channel is well defined by the CHIRP sonar at this site. Core 13 was taken at the center of the channel-fill sequence where the water depth is 14.3 meters below present mean sea level. Core 14 was acquired at a site on the north side of the channel in 14.6 meters below present mean sea level in an attempt to core the channel wall. Both cores penetrated approximately two meters below the seafloor.

The cores recovered three distinct units in the upper two meters of the channel-fill sequence. The basal unit in both cores consists of a gray-to-dark gray silt (Munsel 10YR $5 / 1$ and 4/1) that becomes darker with depth. This silt unit makes up the lower 1.5 meters of each core. Grain-size analysis shows that the unit is mostly composed of silt (88-91\% by weight) with smaller abundances of clay and sand (4-10\% and 5-7\% respectively). Inspection of smear slides and results from X-ray diffraction of several sub-samples from the silt unit show that the silt is mainly composed of quartz, feldspar, and mica particles. Authigenic pyrite and glauconite are also present in the smear slides. Peaks associated with these minerals occur in X-ray diffraction results. No fossils were found in this unit and bedding and internal sedimentary structures were absent. The organic carbon content of four samples from the silt units in both cores ranges between 0.67 and 1.74 percent by weight. The upper one-to-three centimeters of the silt unit is discolored in both cores. In core 13 the top centimeter is composed of a light gray clayey silt that occurs just below and erosional contact with the sand unit above. The upper three centimeters of the silt unit in core 14 is composed of a dark yellowish brown (Munsel 10YR 4/6) clayey silt. The yellowish brown color suggests that this unit partially oxidized indicating sub-aerial exposure in the past.

A sand unit, which varies between 0.36 and 0.42 centimeters in thickness, covers the lower silt unit. Despite the similar appearance of the sand units in cores 13 and 14 , there is a slight difference. In core 13, the sand unit is a moderately sorted coarse sand (0.25-0.5 mm) composed mainly of quartz ( $>95 \%)$. Gravel makes up less than one 
percent of the samples that were analyzed. Sand grains that comprise the unit are rounded to sub-rounded. The color of the sediments ranges from grayish-brown to gray (Munsel 10YR 5/2 to $10 Y R 5 / 1$ ). In core 14 a similar unit is present. It consists of moderate-topoorly sorted very coarse sand. The sand is mainly composed of quartz (85-90\%), feldspar, and rock fragments resembling the sand in the corresponding unit of core 13 . Gravel sized sediments are more abundant in this core, especially toward the lower boundary of the unit. Minor amounts of shell fragments are also present in core 14. In both cores, the upper portions of the sand unit become coarser with a pebble lag present in the upper portion of the unit. The pebble lag is five centimeters thick in core 13 and eight centimeters thick in core 14 .

The pebbly sand that occurs in both cores is covered by another sand unit that varies in thickness between the two cores. In core 13 this unit is 0.32 meters thick and is a dark grayish brown (Munsel 10YR 4/2) moderate-to-well sorted medium sand (0.25-0.5 $\mathrm{mm}$ ). The sand is mainly composed of quartz (90-95\%). Feldspar, rock fragments, and heavy minerals are also present. In the middle of this unit, several dark discolorations are

present. Inspection under a microscope shows that sand grains from these darker areas are coated with fine organic particles. The corresponding unit in core 14 is half as thick and less defined than in core 13. The unit is similar in color to core 13 but textural characteristics differ between the sediments. The surficial sand unit in core 14 is composed of a poorly sorted pebbly sand where the gravel fraction makes up more than 10 percent of the sample weight.

\section{b. Channel $A$}

Nine cores sampled the sediments that fill Channel A. Four sedimentary units were identified from these cores. The four units are: a) a basal gravel unit, b) a fine grained organic silt and clay unit, c) a layered sand and gravel unit, and d) an upper well-sorted sand unit. The latter two units were consistently sampled along Channel $\mathrm{A}$, whereas the former two units are encountered only in longer cores (Figs. $24 \& 25$ ).

The basal gravel unit was sampled only in the base of core 4 (Fig. 24). These sediments comprise the bottom 15 centimeters of this core. Sediments consist of dark brown (Munsel 10YR 3/3) very poorly sorted gravelly sand. Grain size analysis for the sediment show a bi-modal distribution. Thirty-seven percent of the sediment is gravel that averages -3 phi in size, and 66 percent of the sediment is sand between 1 and 2 phi. Small root and twig fragments are also present in this unit. This gravelly sand is interbedded 
toward the top of the unit with finer grained silty sand that makes up the base of the organic silt. Two pockets of gravelly sand occur in the lower 25 centimeters of the organic silt unit.

Fine-grained organic silt and clay facies were encountered in five of the cores that were collected across two of the channel profiles in Channel A (Figs. $24 \& 25$ ). Cores 1 , 2, 4 and 17 acquired from sites of CHIRP profiles 42 and 45, penetrated the fine-grained organic sediments. Only one of these samples, core 4, penetrated the base of the organic silt unit. This boundary occurs 3.9 meters below the seafloor (12.1 meters below present mean sea level). At the base, the organic mud is interbedded with pockets of the previously described gravelly sand. This bedding is only present within the lower 20 centimeters of the organic mud sequence. Above this, the sediment texture for organic muds ranges from clayey silt to silty sand showing no distinct grain-size trend down core. Sediment color varies from dark gray to very dark gray (Munsel 10YR 4/1 and 3/1). Elemental analysis on three samples from the silty organic muds shows that the organic carbon content of the mud ranges from 1.7 to 4.5 percent carbon by weight. Wet sieving the sediment yielded plant, wood, and fine organic fragments. Plant fragments in the sieved sediments were too small to identify accurately. Disarticulated bivalves and gastropod shells are common in the organic silt sediments. Marine bivalves and gastropods occur and are represented by Mercenaria mercenaria, Argopecten, Mytilus edulis, and Crepidula fornicata. In addition, wet-sieved sediments contained a significant amount of gastropods smaller than $0.5 \mathrm{~cm}$ in size. Inspection of smear slides indicates that these sediments are composed mainly of small clastic particles and organic detritus. Fragments of diatoms are also abundant in smear slides from these sediments. The upper boundary of the organic mud occurs between 0.8 and 1.2 meters below the seafloor (10-11 meters below present mean sealevel) in the core. Approaching this boundary, the organic mud becomes more sand prone eventually being replaced by sand and shelly sands, which are lighter in color.

Cores that penetrated the coastal embayment silt and clay facies show that 0.7 -to1.2 meters of sand rests over the fine-grained sediments. These sands consist of three distinct units. The deepest of these units rests over the organic mud and is composed of moderately sorted coarse and very coarse sand. The sediment texture is not uniform through this unit but varies from coarse to very coarse sand. The sand color is mottled with fine organic fragments which adhere to sand grains. The high organic content of these sands causes the sand coloring to vary from grayish brown to very dark gray (Munsel 10YR 4/2 to 3/1). Disarticulated and fragmented bivalve shells are common. In a few 
cases, moderate-to-well sorted pockets of very coarse sand occur towards the base of this unit. Shell fragments and organic material are not apparent in these intervals. In core 4, the base of this unit contains a four-centimeter thick accumulation of detrital plant material consisting of broken plant fragments that caps an eight centimeter layer of well-tomoderately sorted fine sand. The small size of fragments of the plant remains $(<0.5 \mathrm{~cm})$ made them impossible to identify with any degree of certainty under the microscope. A thin unit ranging from 15 to 30 centimeters thick occurs in two of the cores. This unit is composed of a moderately-to-well sorted very coarse sand. The sand that comprised this bed was almost completely composed of quartz. This unit is succeeded by a unit that is comprised of gravelly very coarse sand and fragmented shell material. Gravel abundances approach 25 percent of the sample weight. This unit ranges between 10-15 centimeters thick to as much as 40 centimeters thick. The sediment color of this unit was grayish brown-to-dark gray (10YR 4/2 to 4/1). The gravelly sand is mainly composed of quartz and feldspar. The gravel consists mainly of rock fragments. Shell fragments are also abundant. The shell fragments are commonly one centimeter in diameter, and occasionally up to five centimeters. This unit is also encountered in five other cores acquired from sites along Channel A. These other cores failed to penetrate the lower boundary of this unit.

The upper-most of these sand units, which is exposed to the seafloor, occurs in all the cores taken from Channel A. This unit ranges between 10-to-50 centimeters thick. It is composed of a moderate-to-well sorted medium sand that consists mainly of quartz $>$ $90 \%$ ). The color of this surficial unit varies from grayish brown to dark gray (10YR 5/2 to 4/1). The boundary with the lower gravely unit is in some cases a subtle transition from very coarse sand with gravel to a medium sand. In other cases the transition is more abrupt resulting in a distinct boundary. Fine grained layers within this unit composed of silty sand, occur in a few of the cores.

\section{c. Channel B}

Sediments in Channel B were difficult to penetrate. Four coring attempts resulted in two cores from one location along this feature. Both cores sampled the same units. Because core 16 is twice the length of core 15 , the former is used for this analysis. Core 16 penetrated two sandy units that comprise the upper portion of the channel sequence in this feature. The two sedimentary units were sampled at one core location coinciding with the channel profile in survey line 30 (Fig. 26). The lower 1.06 meters of core 16, which is 1.48 meters in length, consists of poorly sorted gravelly coarse sand with abundant shell 
fragments. The gravelly sand is mainly composed of quartz (80-90\%) with lesser amounts of feldspar and rock fragments. Heavy mineral grains are also present in small amounts. The sand is light brownish gray in color (Munsel 10YR 6/2). The upper 42 centimeters of sediment in core 16 consists of a very dark gray (Munsel 10YR 3/1) coarse sand with pebbles. This unit is discolored with dark organic fragments which saturate the pore waters giving the sediment a strong pungent odor. Shell fragments are visible throughout the unit $(<1 \%)$. This darker unit forms the surface unit which is exposed at the seafloor.

\section{d. Channel $C$}

One core was taken from the channel-fill sequence in Channel C. Sediments in the lower 1.37 meters of this core are composed of a fine grained silt that range in texture from sandy silt to silt that gradually becomes more peat rich with depth (Fig. 27). The lower 30 centimeters of this unit consists of silty peat. Upper portions of the silt unit are very dark gray in color (Munsel 10YR 3/1) while lower portions of the unit are dark grayish brown (Munsel 10YR 3/2) and dark brown (10YR 2/2). The peat rich portions of the lower silt unit are black in color. The peat consists of compacted fine plant remains that were too small to identify. Several pockets of moderately sorted coarse sand also occur in the lower portions of the silt unit. Except for diatoms, fossils are absent from the silt unit. Microscope inspection of several samples that were wet sieved through a 63 micron sieve yielded no foraminifera. Smear slides indicate, however, that diatoms are present. Identification of the diatoms is impossible as many were crushed during smear-slide preparation. The total organic carbon content of the silt unit is 3.66 percent by weight. Organic carbon measurements of the peat rich regions of the silt reach 10.59 percent by weight. A coarse sand, that is mainly composed of quartz ( $>90 \%)$, conformably succeeds the silt unit. The middle of this unit is divided by a thin gravelly coarse sand containing layered shell fragments. This gravelly bed appears similar to the sand above except for the presence of fragmented shells and gravel. Below this layer the sand is moderate-to-poorly sorted with a dark gray color (Munsel 10YR 4/1). Above the gravel layer, the sand is well sorted and grayish brown in color (10YR 5/2). Small shell fragments, less than a centimeter in diameter, are present in this portion of the sand unit.

\section{e. Channel $E$}

One core penetrated the upper portion of the channel-fill sequence in channel $\mathrm{E}$ (Fig. 28). The lower 3.5 meters of this unit consists of a dark gray (Munsel 10YR 4/1) 
unit composed of silt-sized sediments. Sand and clay are present in minor amounts $(<$ $5 \%$ ), except in the lower half of the unit where the clay content becomes more significant $(5-10 \%)$. This unit is similar to the silt unit encountered in cores 13 and 14. X-ray diffraction results are similar between the two units showing that these sediments are mainly composed of quartz and feldspar with lesser amounts of sulfide and clay minerals. Mica is also abundant in the samples. Like cores 13 and 14, smear slides show that these sediments contain glauconite and Authigenic pyrite, two minerals common in marine sediments. This silt unit is also devoid of fossils. Total organic carbon concentrations for the silt in this unit range from 0.67 to 1.43 percent by weight. The upper meter of this unit appears to have been partially oxidized indicating sub-aerial exposure. The color of the sediment in this portion of the silt unit changes from dark gray and gray becoming mottled with dark grayish brown and dark brown (Munsel 10YR 4/1 and 5/1 to 4/2 and 3/3).

Above this mottled zone, a sandy unit rests on top of the silt unit. The boundary between the two units is subtle but appears to represent an unconformity. Above the boundary, sediments are composed of a moderate-to-poorly sorted fine sand. This sand is dark gray in color (Munsel 10YR 4/1) and contains shell fragments unlike the silt unit in which there are no fossils. This sand unit is then overlain by another sand unit. This bed is composed of moderately-to-well sorted medium sand which is mainly composed of quartz (circa 95\%). This sand is yellowish brown in color (Munsel 10YR 5/4). The middle portions of this sediment unit are saturated with fine organic material that give the stained portions a black appearance. Towards the base of the unit the color of the sand gradually becomes darker, similar to the dark gray color of the sand unit below.

\section{f. Small Channels}

Two additional cores were also acquired from the two small channels that were identified on the western edge of the study site along CHIRP survey lines 3 and 5 (Fig. 29). Core 11 penetrated the channel-fill sequence in one channel to a depth of 2.3 meters below the seafloor (10.4 meters below mean sea-level) and core 18 penetrated a nearby channel sequence to a depth of 4.5 meters below the seafloor (12.3 meters below present mean sea level).

Core 11, acquired at the site of a channel-fill sequence imaged in survey line 3, penetrated a sequence of tidal flat sediments capped by gravelly very coarse sand (Fig. 29). The lower 20 centimeters consists of a black (Munsel 10YR 2/1) clayey fine peat. This peat is mainly composed of compacted fine organic particles. The total organic carbon 
content of this peat-rich silt is 5.91 percent by weight. Toward the top of the peat unit, the peat content decreased and is replaced by organic clayey silt. This very dark gray (Munsel 7.5YR 3/1) clayey silt makes up the bulk of the core. The sediment texture is uniform throughout this unit. Wood fragments and shells are common throughout the sequence. A few articulated shells of Mercenaria mercenaria occur at several intervals in this sequence. Two of these shells, which appeared to be preserved in-place, were radiocarbon dated yielding dates of $3790 \pm 70$ and $3640 \pm 90$ years B.P. These shells occur at elevations of 9.75 and 9.9 meters respectively below present mean sea-level. Since these specimens are articulated and filled with internal molds composed of fine-grained organic mud, it was thought that they had not been reworked since they expired in living position. In the upper portion of the clayey silt sequence, there is an interval of coarser-grained, gravelly very coarse sand interbedded within the silt. This sand bed is saturated with the organic mud that comprises the silt unit. The upper 30 centimeters of the clayey silt sequence contains a large proportion of gravel and pebble sized grains gradually and becomes less silt saturated at the upper boundary. The decrease in the mud content of the gravel is reflected by a color change between the silt units and the clayey silt. The upper 15 centimeters of the sequence is grayish brown (10YR 5/2) while the portions which are saturated with the organic clayey silt are very dark gray (Munsel 7.5YR 3/1). Shell fragments are common in the gravel. These sediments are rounded and mainly composed of quartz, feldspar, and rock fragments. The upper gravel unit that makes up the top portion of the core is exposed on the seafloor.

The core from the channel imaged in CHIRP survey line 5 contains a similar fine grained sequence (Fig. 29). The sediments in core 18 consist of a lower organic silt unit covered by gravelly sand. The silt unit comprises the bottom 3.9 meters of the core. This unit rests over a dark brown (10YR 3/3) medium sand similar to the one encountered at the base of core 4 on the other side of the study area. This sand is composed mainly of quartz and feldspar. Sand grains are also angular to sub-angular. Unlike the basal sediments in core 4 , no gravel is present in the sand unit. The base of the organic silt unit contains a significant amount of fine organics in the lower 15 centimeters of the unit. Closer inspection of these sediments indicate that this material is composed of very fine organic fragments mixed with silt. The rest of the unit consists of very dark gray (Munsel 10YR 3/1) organic silt. The color of the mud changes slightly to very dark gray (7.5 YR 3/1) in the lower half of the unit. Two measurements of the organic carbon content of the silt sediments yielded values of 3.74 and 5.54 percent by weight. Disarticulated shells of 
Mercenaria, Mytilus, Argopecten and Crassostrea are sparse in the upper half of this unit. A five centimeter rock clast that is partially encrusted with fenestrate bryozoans occurs in the middle of the organic silt unit in this core. The top 60 centimeters of the silt unit becomes sandier. Within 70 centimeters of the top of the core, the sediment composition changes to a muddy gravelly sand that is dark gray, similar to the mud below.

Disarticulated shells are common in this unit. Species are similar as before but also include specimens of Crepidula fornicata, another marine species. This layer is overlain by 25 centimeters of moderately sorted coarse sand. The sand is almost entirely composed of quartz with minor abundances of feldspar, lithics, and shell fragments. The nature of the boundary between the two sand units is unclear due to over-penetration of the vibracorer which distorted the upper 30 centimeters of the core sample.

\section{Facies Interpretations and Relation to CHIRP Images}

Sedimentary sequences sampled in the seven channels across this study site clarified the relationships between the channels that make up the offshore network. Based on the channel-fill stratigraphy, two principal sequences were identified. The first sequence, which was sampled from Channel $\mathrm{E}$ and the Trunk Channel, consists of latePleistocene glacial deposits that are capped with former beach and modern seafloor facies. The other sequence which was sampled in Channels A, B, and C as well as the smaller channels, consists of a Holocene transgressive fill that reflects the onshore migration and drowning of late-Pleistocene paleo-channels. The presence of these two sequences suggest that the offshore channel network defined in this region may not consist of a single channel system or that the overlying channel fill was not deposited across the entire region.

\section{a. Trunk Channel}

The sedimentary sequences in cores acquired from the trunk channel consist of glacial, shoreface, and modern seafloor sediments. The fine-grained texture and the lack of organic material and fossils suggests that the basal silt unit is probably a quiet-water glacial deposit that accumulated in response to late-Pleistocene glacial melting. The basal silt unit is similar to a late-Pleistocene glaciolacustrine unit sampled in several cores acquired by O'Hara and Oldale (1987). In their study, cores along the northern portion of Vineyard Sound and the northwestern corner of Nantucket Sound penetrated a silt and clay unit overlain by sand units (Fig. 30). Sediments in these silt and clayey silt units were also devoid of fossils like those sampled in cores 13 and 14. Total organic carbon 
measurements also show that the sediments in cores 13 and 14 sediments have distinctly lower organic carbon concentrations than those of the organic muds sampled from Channels A, C and the two smaller channels (Table 3). Varves were observed in this unit from the cores acquired by O'Hara and Oldale (1987). The texture of the basal silt in core 13 and 14 is similar to the description of the O'Hara and Oldale (1987) cores, but lacks varves. It is possible that varves were destroyed upon acquisition and in post-acquisition core handling. Sediments that make up this basal silt unit flow readily upon agitation, and the cores were likely agitated during transport.

The mineralogy of the silt unit sampled in the present study is not diagnostic. The silt is composed mainly of fine quartz, feldspar and mica fragments. Glauconite, a mineral common to marine environments, was noticed in several smear slides. Authigenic pyrite, which can occur in a variety of deposits, is also present. On Cape Cod glauconite occurs commonly in glacial deposits reworked from Tertiary Coastal Plain sediments (Elazar Uchupi, pers. comm., 1998). Authogenic pyrite forms in aqueous reducing environments and can occur in lake, marsh, and marine deposits (E. Uchupi pers. comm., 1998).

The sand unit that occurs directly over the silt unit is interpreted to be a Holocene beach/shoreface deposit. Near uniform sediment grain-size $(0.25-0.5 \mathrm{~mm})$ and the absence of fine sediments show that this was probably a shoreface environment such as a beach. The lower boundary with the silt unit represents an unconformity. The abrupt shift in sediment size and the presence of discoloration at the top of the silt unit in both cores indicates that the upper portion of the silt deposit was eroded. The reddish discoloration in core 14 suggests that this portion of the unit was exposed to the atmosphere resulting in the oxidation of the silt and clay that comprise this layer. The light gray discoloration in core 13 is not easily explained. In the context of the sea-level history of this region, this beach deposit is thought to be a Holocene transgressive deposit cut into the lower silt unit. Alternatively, this could also represent a late-Pleistocene regressive beach that was deposited over top of the glaciolacustrine deposits in response to diminishing lake levels. More data is needed to make this distinction as the judgment was made from only two core samples in one location. The upper boundary of this sand unit also records a change in sedimentary environments. The pebble lag in the upper portion of the lower sand unit forms a boundary between two different types of sand. The lower sand is rounded and moderately-sorted coarse sand ranging from 1 to 2 phi and mostly composed of quartz. The upper sand unit is well-sorted and finer with sizes between 2 to 3 phi and composed of a greater percentage of feldspar. The upper sand unit is composed of modern sands which 
are being reworked at present. These sands are incorporated in the sand waves present in this portion of the study area.

The nature of the two facies boundaries that were identified in the cores acquired from the Trunk Channel suggest that they are unconformities. The lower boundary, between the silt and lower sand unit is interpreted to be an erosional unconformity. In the context of rising relative sea-levels, this unconformity was probably cut into the glaciolacustrine silt deposits during the Holocene transgression as shoreline environments back-stepped over this site with continued sea-level rise. The lower unconformity could also represent a late-Pleistocene regressive boundary where beach facies prograded basinward infilling the glacial lake. The unconformity defined by the pebble lag that separates the two sand units appears to record the shift from a shoreface or beach deposit to nearshore marine deposition.

\section{i. Correlation to CHIRP Stratigraphy}

CHIRP profiles of the channel sequence where cores 13 and 14 were taken allowed us to extend the interpretation of this sequence (Fig. 31). Despite limited core penetration $(2.26 \mathrm{~m})$, CHIRP images at the site of core 13 enable partial correlation of the core to the seismic record at the center of the channel. Layered reflectors across the upper portion of the Trunk Channel appear to have imaged the two surficial sand units. These units are not individually defined as their thickness approaches the resolution capability of the CHIRP profiler. The base of the layered reflectors correlates to the unconformity between the silt and the sand. The stratigraphic position of the silt unit defined in the cores coincides with the position of the transparent unit beneath the layered reflectors. Based on the CHIRP profile of this channel sequence, this unit appears to extend at least as far as the U-shaped internal reflector in the transparent channel fill. The limited intensity of this reflector in comparison to other reflectors in the profile suggest only minor internal differences in acoustic impedance.

Core 14 is more difficult to correlate to the CHIRP data due to poor image quality of this portion of the channel sequence. Nevertheless, this core, which is comparable to core 13 , represents the same sequence along the flank of the channel. The main difference is in the top sand unit, which is not as thick as in core 13. The lower silt unit is similar along the side of the channel fill. This unit appears to extend to the channel wall. 


\section{b. Channel A}

Four sedimentary facies are recognized in the cores that sampled the channel-fill sequence in Channel A. The lower most of these sediments sampled from Channel A consists of a sand and gravel unit that was sampled from the channel wall. These sediments are interpreted to be part of the late-Pleistocene glacial outwash deposits because of their sand and gravel composition. Findings form O'Hara and Oldale (1987) also support this interpretation. O'Hara and Oldale (1987) showed that channels observed in Nantucket Sound are eroded into the late-Pleistocene glacial drift sediments. The presence of small root and twig fragments suggests that this unit may have been sub-aerially exposed during periods of lower relative sea-level. During this time this unit would have formed a substrate for soil formation and vegetation. Sand and gravel are also commonly found in fluvial deposits. Although fluvial sediments are often encountered at the base of flooded channels and paleo-valleys in many settings, it is difficult to account for the presence of root and twig fragments in a sand and gravel deposit in this situation. Currents associated with fluvial sediments are commonly too strong to allow deposition of fragments such as small root hairs or small wood fragments.

Above the channel substrate, cores recovered fine-grained organic mud in Channel

A. This organic mud probably accumulated in a coastal embayment. The fine grained texture and organic content of the sediment indicates that these deposits accumulated in a high-productivity, low energy environment. The presence of marine bivalve remains indicate that this environment was connected to the coastal ocean. Core 4, which penetrated the glacial outwash that formed the channel substrate, shows that the mud unit rested directly over the glacial unit. The boundary between the two units records the Pleistocene-Holocene contact. This transition also forms the pre-transgressive/ transgressive boundary. The thin interbedded intervals above the mud-gravel transition most likely reflect small-scale mass wasting of the formerly exposed valley wall.

The sand and gravel units that vertically succeed the organic muds are believed to be back-barrier, beach and barrier spit, and tidal inlet sediments. These sand units consisted mainly of gravel to coarse-sand sized sediments. Shell fragments, which are common in beach, barrier, and inlet sediments, occur throughout these sand units. The range of sediment sizes, within the range of sand and gravel, made it difficult to infer the precise depositional environment for each of these deposits. Nonetheless, it is inferred that silt and organic saturated sand beds that occur at the base of the sand units probably represented back-barrier depositional environments on the landward side of former barriers. In core 4 , 
a plant layer that occurs in this lower portion of this sand unit possibly records the accumulation of detrital plant matter in a back-barrier environment. Inlet and beach environments are often too energetic to allow deposition of fine grained organic fragments and silt-sized sediments. The upper unit of the beach and barrier sand is consistently comprised of a gravelly sand with shell fragments in all the cores that penetrated Channel A. These sediments most likely reflect beach deposits that formed during periods of lower sea-level.

The coarse sand and gravel units are all covered by well-sorted medium sand that is present on the modern seafloor. The mature sorting and near homogeneous quartz composition of this sand unit along with its situation on the modern seafloor indicates that this sand is probably being continuously reworked and re-deposited.

One unconformity is identified in the channel-fill sequence sampled from Channel A. The lower unconformity, which defines the base of channel-sequence, occurs between the basal sand and gravel and the organic silt. This surface represents a shift from subaerial exposure during the late Pleistocene to a Holocene coastal embayment environment. A few other erosional surfaces are present in the rest of the channel sequence. One occurs between the organic silt and the barrier-spit, inlet, and beach sand and gravel units. Others occur between the different individual sand and gravel units covering the silt. Because of the range of grain-sizes and sorting that can be associated with beach, inlet, and barrier spit deposits, as well as the absence of bedding structures which can be interpretive tools, it is difficult to accurately delineate the precise boundaries between these units and their significance. The upper most is situated at the boundary between the gravelly sand and the modern seafloor sand. This surface represents the depth to which former shoreface deposits were eroded during the flooding and shoreward migration of the coastline during relative sea-level rise.

\section{i. Correlation to CHIRP Stratigraphy}

In the seismic data, the organic muds that made up the bulk of the channel sequence correlate to the transparent channel-fill imaged along the extent of the channel (Fig. 32). Although only one core penetrated the base of this unit, seismic data shows that this unit extends to the base of the channel sequence and rested above the valley-wall that forms the Pleistocene-Holocene contact. Data from the base of core 4 indicates that this contact is most likely composed of the pre-transgressive glacial drift associated with outwash plains on this portion of Cape Cod. Images from two CHIRP lines indicate that an additional 
acoustic unit occupies the base of the channel. No cores penetrated this seismic unit. The second distinct sedimentary unit, the back-shore/inlet sands, cap the coastal embayment sediments. These sediments form the upper portions of the channel-fill sequence. The base of this unit is denoted by the high-amplitude reflector that bounded the top of the transparent unit in these channels. This reflector probably results from the large change in acoustic impedance between the organic mud deposits and the sands that overlie them. Cores that sampled this unit reveal changes in sediment texture reflecting different subenvironments or depositional events associated with barrier spits and inlets. These changes are not clearly defined in the CHIRP record because the limited thickness of these different units approaches the vertical resolution of the CHIRP profiler. In addition, the small changes in impedance between these sand units is not as pronounced as those between the sand and the mud which resulted in less well developed reflector. The third sedimentary body that consists of the modern sand unit, is partially defined by the CHIRP sonar. This unit is defined by the thin layered acoustic units that occur above portions of Channel A. Even though this unit occurs in all the cores, it is not well defined across all of the CHIRP images of Channel A. In areas where it is not well defined in the CHIRP records, cores show that the sand unit was less than 30 centimeters thick approaching the vertical resolution of the seismic profiler. Moreover, this unit also occurs at the seafloor and may be masked by the high-amplitude reflection of the seafloor in the CHIRP record. Nevertheless, cores and CHIRP profiles used in tandem have allowed for a better definition of the channel-fill stratigraphy.

\section{c. Channel $B$}

The sediments encountered at the core site in Channel B appeared only to have penetrated the upper portion of the channel sequence. These sediments, which are composed of a sandy gravel with shell fragments, are interpreted as a beach and/or barrier spit and inlet sediments. In the context of the relative sea-level history of this region, these deposits probably developed as the shoreline migrated across this region in response to rising relative sea-level. The organic rich sand unit that rests over the sandy gravel is not well understood. The texture of the sediments that makes up the matrix of this unit is composed of similar sediments to the sandy gravel below. The high organic content of this unit which was exposed at the seafloor; however, is difficult interpret. Due to the short core lengths, no distinct stratigraphic boundaries are identified in the cores. 


\section{i. Correlation to CHIRP Stratigraphy}

Having only penetrated the upper most sediments in the channel-fill sequence, the results of Channel $\mathrm{A}$ and the similarities in the CHIRP stratigraphy between the channels (A \& B) were useful to extend the analysis of Channel B. Channel B like Channel A, is based in a similar channel unconformity (Fig. 33). The base of the channel is filled with a transparent acoustic unit. A good quality CHIRP profile from Channel B, along survey line 32, imaged this unit. These images also show that a strong high amplitude reflector caps the transparent fill. Coring data from A allow the speculation that this transparent unit in Channel B probably consists of similar organic silt and clay sediments. One profile, from survey line 30 , show that this unit is discontinuously layered and more difficult to delineate. In these profiles, there is no distinct reflector that appears to cap the channel fill as in the other profiles.

\section{d. Channel $C$}

Like the other channels containing transgressive channel-fill sequences, the sedimentary sequence in this channel records Holocene deposition in a small coastal embayment. The sedimentary sequence in core 12 consists mainly of an organic silt unit that is replaced by peat-rich silt with depth. The peaty sediments reflect deposition in a paleo-marsh setting along the fringe of a small coastal embayment. The organic silt unit, which succeeded the peat, is comparable in description to those described for small coastal embayments in Maine and Rhode Island (Boothroyd et al., 1985; Duffy et al., 1989). The lack of marine bivalves and gastropods in the organic silt unit implies that this embayment may have had limited contact with the ocean. The small size and limited spatial extent of the channel that accommodated this embayment may have been too small to maintain an inlet. The sand units that cap the finer grained coastal embayment sediments indicate that beach and barrier spit sediments were deposited above the coastal embayment sediments as this channel was progressively drowned. A shell lag, covered by finer sands than those below the lag, probably represents the transition from a protected paralic environment to shoreface and nearshore marine environments.

\section{i. Correlation to CHIRP Stratigraphy}

CHIRP records from core site 12 could not be clearly correlated to the sedimentary sequence that was sampled. High-amplitude reflections blurred the CHIRP images making 
lithologic correlation difficult. Sediments at the base of the core sequence suggest that biogenic gas from peaty sediments, caused the blurred CHIRP images. The organic silt that replaces the peat in the vertical sequence is reflected by a poorly defined semitransparent fill above the blurred high-amplitude reflection in the CHIRP profile of this channel (Fig. 34). The surface sand units were not well-imaged. In addition, the gasblurred CHIRP images did not clearly image the base of the channel and thus the lower boundary of these channels is inferred.

Even though evidence from the cores showed that a small coastal embayment with limited exchange with the coastal ocean occupied this low, the complete history of this embayment was not sampled. CHIRP records, although blurry, indicates that this sequence may extend 4-to-5 meters below the seafloor. Sediments below this depth may record variations in the depositional history of this channel.

\section{e. Channel $E$}

The interpretation of the stratigraphy in core 19 is similar to cores 13 and 14 , which were sampled from the Trunk Channel. The silt unit that forms the lower 3.6 meters of the unit appears to be a pre-transgressive deposit related to the glacial origin of this site. The fine grained sediment and its lack of fossils suggests that this deposit is a late-Pleistocene glaciolacustrine unit similar to the one sampled in the Trunk Channel. Like the silt cored in the Trunk Channel, the organic carbon content of these sediments is distinctly less than the Holocene channel fill sediments sampled in Channels A, C, and the two smaller channels.

Glauconite and authigenic pyrite are also present in the sediments that compose the silt unit at this site. Due to sampling distribution and disturbance during post-acquisition core handling, the presence or absence of varves could not be determined.

Upon inspection, smear slides form both silt units appear to be comparable. Both units were composed mainly of quartz feldspar and mica grains. Authigenic pyrite and glauconite were also present in all three cores. Fossils are absent. The unconformity between the silt and sand units in the core suggest that the upper portions of the silt unit were eroded. Shoreface erosion due to transgression and post-transgressive reworking appear to have eroded into the silt unit depositing layers of sand. The two sand units that were deposited above the silt unit are interpreted as former beach and nearshore deposits. The lower sand which is composed of moderately sorted coarse sand and gravel with shell fragments is interpreted to be a beach deposit. The mature sorting of the sands in the upper 
sediment unit and their near total quartz composition suggest that these sediments have been extensively reworked. This sand unit is currently being reworked and deposited.

Only one unconformity is defined in core 19. This boundary, which occurs between the silt and the sand, was similar to that identified in cores 13 and 14 from the trunk channel. This unconformity is interpreted to be the late-Pleistocene/Holocene contact representing the transgressive reworking of the silt unit as shoreface environments migrated landward. This boundary could also be identified as a regressive boundary where a beach deposit eroded into and was deposited over sediments that accumulated in a receding lake. No unconformity was identified between the two upper sand units. This was thought to be a consequence of over-penetration and sediment disturbance during vibracoring.

\section{i. Correlation to CHIRP Stratigraphy}

Correlation of core 19 to the CHIRP image across survey line 8 enabled further definition of the stratigraphy in this channel (Fig. 35). The basal silt unit in core 19 correlates directly to a thickly layered fill in the channel image. Although CHIRP records indicate that this fill was thickly layered in places, no such layering was evident in the core sedimentology. Variations in the velocity and or porosity of the silts and clays of this fill may have caused the layering in the CHIRP record. The upper truncation of this unit in the seismic record was also recorded in core 19 . This boundary corresponded to the unconformity between the silt and the upper lower sand unit in the core.

\section{f. Small Channels}

Sediments sampled in the small channels on the western side of the study site also record the Holocene evolution of a small coastal embayment similar to those that were sampled from Channels A and B. Cores contain slightly different sequences reflecting different sub-environments of a coastal embayment.

Core 11 penetrated a transgressive sequence in imaged in CHIRP survey-line 3. The base of the core contains a peat unit that indicated the presence of a marsh environment at this location. In-place articulated Mercenaria shells, deposited in the organic silt unit that overlies the peat, indicates that a tidal flat environment accreted in the channel and buried the marsh. The gravel at the top of the core, which is partially interbedded with the tidal flat mud appears to replace the organic silt. This very coarse sand and gravel unit is probably associated with a beach or barrier environment. The exposure of these sediments

at the seafloor suggests that the upper portions of the transgressive sequence have probably 
been reworked and eroded from this location or not deposited. The absence of sand similar to the shelf sand and inlet/barrier spit facies that were sampled at other sites support this interpretation. It is difficult to determine how much of the channel sequence was sampled in core 11 since gas inhibits the resolution of the CHIRP images at the base of the channel.

Core 18 penetrated the entire transgressive sequence in the small channel imaged in survey-line five. Sediments in this sequence record the evolution of a small coastal embayment. The base of the sequence appears to rest over the pre-transgressive substrate, believed to be late Pleistocene glacial outwash that composes the surrounding portion of Cape Cod. Only a small interval of these sediments were recovered in the base of the core, yet the similarity of these sediments to those encountered in the base of core 4, which also penetrated below the base of the channel, suggests a glacial outwash origin. The main difference between these two samples was the lack of gravel in the sand at the base of core 18. The upper surface of the basal sand deposit forms the base of the channel. The channel unconformity separates previously exposed glacial outwash deposits from the organic silt that covered this unit. Organic silt deposited in a quiet-water marine setting make up the bulk of the sequence in this core. The base of the silt unit has a higher organic content than shallower portions of the unit and may reflect marsh environments, which were established during the initial flooding of the small valley. The presence of disarticulated marine bivalve remains indicate that this embayment was in contact with the ocean. The silty coarse sand that replaced the silt sequence at the top of the core indicated a higher energy depositional environment. The presence of the silt in the coarse sand suggested that this deposit may have formed in a sheltered region where fine grained organic-bearing sediments could have accumulated. A marginal tidal flat environment is one candidate environment. The upper-most sand unit appears to consist of modern seafloor sand that was encountered in cores from other channels. The boundary between this sand unit and the one below was difficult to assess due to the core distortion caused by over-penetration of the core barrel.

\section{i. Correlation to CHIRP Stratigraphy}

The upper two-to-three meters of these cores can be related to CHIRP images of these channels (Fig. 36). The lower peat bed at the base of core 11 correlates to the gas reflection in the CHIRP profile in the channel imaged in line 3 . The source of the gas reflection in line 5 was less definitive than that in core 18. The sediments in this core are not classified as peat due to the clayey silt texture of the sediments. Elemental analysis of 
the sediments in this core showed that the organic silty clay toward the base of the sequence had a high organic carbon content (5-6\% by weight). This high organic content may have caused the gas distortion of the CHIRP image of this channel. Semi-transparent units situated over the gas reflections correlate to the organic silts and muds in the both of these cores. These units represent open water and tidal flat deposition in the coastal embayments which occupied these channels. The sand units that occupy the upper portions of the sedimentary sequence in these cores are not well resolved in the CHIRP records.

\section{Sequence Stratigraphy of Channel-Fill Deposits}

Several terms must be defined prior to their application to the sedimentary sequences present in the channels in this study. Three main terms must be defined. First, the sequence boundary reflects the limit of erosional down-cutting in response to a baselevel fall. The second is the transgressive surface. This surface separates the transgressive systems tract from the lowstand systems tract and reflects a transition from basinward to landward migration of the shoreline. The third stratigraphic surface that must be defined is the ravinement surface. Here it is defined as the stratigraphic surface that records the first regional flooding of inter-channel areas. Over inter-channel areas, the three stratigraphic surfaces coalesce. Over incised channels these three surfaces can diverge depending on sediment supply. In this situation, the intervening sediments are typically associated with fluvial and paralic deposits such as fluvial-estuarine or lagoonal sequences (See I. Introduction: paragraphs 2 and 3).

The channels at this study site exhibit two different channel-fill patterns. The first sequence was defined based on cores from the Trunk Channel and Channel E. The other channel-fill sequence type was defined based on results from Channels A, B, C and the two smaller channels.

Sedimentary sequences from Channel $\mathrm{E}$ and the Trunk Channel exhibit relatively limited transgressive systems tracts that were deposited over a unique sequence stratigraphic situation (Fig. 37). In these channels, the glaciolacustrine silt unit forms the bulk of the channel sequence and appears to overlie the sequence boundary. Since cores were only able to penetrate the upper third of this sequence, it is not known if lowstand fluvial deposits are present at the base of the sequence. The boundary between the latePleistocene glaciolacustrine silt and the Holocene beach/shoreface sand was interpreted as the ravinement surface and forms the base of the transgressive systems tract. In this case, 
this surface is also the transgressive surface. The transgressive systems tract overlies the late-Pleistocene glaciolacustrine silt, which was deposited from a base-level independent source controlled by ice melting, lake level, and sediment supply. Over the inter-channel highs the ravinement surface, the transgressive surface, and the sequence boundary converge. The transgressive systems tract that overlies the ravinement surface is comprised of two sand units that rest above this boundary; a lower beach face/shoreface or barrier spit lithosome and a nearshore lithosome. These two deposits reflected landward migration of the shoreline. The presence of the intervening glaciolacustrine sediments make the sequence stratigraphy of the Trunk Channel and Channel E unique from other channel-fill sequences as they reflect deposition by a process not directly related to base level fluctuations.

The sedimentary sequences defined in the Channels $\mathrm{A}, \mathrm{B}$, and $\mathrm{C}$ harbored thicker Holocene transgressive systems tracts (Fig. 38). The sequences present in these channels consist of several sequence stratigraphic components. The transgressive sequences are bounded by the sequence boundary which was eroded into the pre-transgressive, latePleistocene glacial-drift surface. Over most of the late-Pleistocene channel surface, the transition to the Holocene organic silt infers that this boundary can also be interpreted as the transgressive surface. Since the deepest portions of these channels were not penetrated by cores, it is unclear whether the basal acoustic units that are imaged are lowstand fluvial units or transgressive marsh deposits (See A. CHIRP Stratigraphy: Channel A). In these channels, the Holocene transgressive systems tract consists of fine-grained coastal embayment and shoreline deposits that accumulated and were reworked during the relative sea-level rise. The ravinement surface was traced from inter-channel regions, where it coalesces with the sequence boundary and transgressive surface to the channels where it diverges from the sequence boundary and the transgressive surface (Pleistocene glacial drift sediments). In a few CHIRP profiles, this surface was most evident along the sides of the channels where a flat-lying reflector truncates the upper reaches of the channel wall (pretransgressive substrate). Over the channels, this surface was better distinguished in the cores than in the CHIRP profiles. It was difficult to precisely identify the ravinement surface based on CHIRP images since the thickness of the sand layers in the upper portion of the channels approached the vertical resolution of the CHIRP profiler. Based on the cores, the ravinement surface was interpreted to coincide with the base of the shoreface sand and gravel deposits as they represent the depth to which the channel sediments were reworked as the shoreline migrated landward. 
The three smaller channels showed sequences similar to those described in Channels A, B, and C. The interference effects of biogenic gas reflections make it difficult to interpret the internal stratigraphy in these channels. Nonetheless, cores show that the stratigraphy of these channels is comparable to that of channels A and B. The bulk of the sequences consist of marsh, coastal embayment, and shoreface deposits recording a landward facies shift during the transgression.

The sequence stratigraphy of the second channel transgressive systems tract is similar to those noted in other settings where the rate of sea-level rise is greater than the sediment supply to a given coast (e.g. United States east coast: See Demarest and Kraft, 1987). In Channels $A, B$, and $C$ as well as the two smaller channels defined in lines 3 and 5 , the ravinement surface diverged from the lower sequence boundary and the transgressive surface. The intervening sequence consists of a Holocene transgressive systems tract comprised of marsh, coastal embayment, shoreface sediments, and nearshore sand. The sequence stratigraphy of the Trunk Channel and Channel $\mathrm{E}$ has a glaciolacustrine unit, which was deposited independent of base-level forcing and filled most of the channel with a thin transgressive systems tract above.

\section{Discussion}

Sedimentary sequences, sampled and imaged with vibracores and CHIRP subbottom profiles, revealed two distinct channel-fill types that accumulated in a latePleistocene channel network offshore of Popponesset, Massachusetts. The first fill-type (transgressive channel-fill), sampled and imaged in five separate paleo-channels, consists of Holocene transgressive sequences comprised of quiet-water coastal embayment sediments capped by beach and barrier-spit associated sand and gravel, and nearshore sand facies. These sequences reflect the drowning, infilling, erosional truncation, and offshore burial of paleo-channels that are embedded in the glacial landscape on the south shore of Cape Cod during periods of lower Holocene sea level. The second channel-fill sequence (glaciolacustrine channel-fill) is probably related to the late-Pleistocene glacial retreat from this region. The glaciolacustrine channel-fill consists of a sequence of silt and clay deposited in a glacial lake that were later eroded and covered with transgressive shoreface and nearshore deposits. The presence of these two fill types suggests that the channel network mapped across the study site consists of two paleo-channel systems. Sediments 
associated with the transgressive channel sequence provided sufficient information to reconstruct the geological evolution of this coast during the last 6000 to 7000 years.

\section{A. Transgressive Channel-Fill Sequence}

The transgressive sediments encountered in Channels A, B, and C as well as the smaller channels on the western edge of the study site, record the evolution of coastal embayments under the influence of relative sea-level rise in the mid-to-late Holocene. CHIRP images, which defined the channels and the sedimentary sequences that fill them, showed that the channel floors extend between 11 to 16.5 meters below present mean sea level with widths ranging from 110 to 300 meters wide.

Cores from Channel A, which were correlated with CHIRP images of the channelfill sequences, indicate that this channel was eroded in late-Pleistocene glacial outwash sediments consisting of sand and gravel. Root hairs and twig fragments that were encountered in the basal sand and gravel sediments show that these paleo-channels were exposed sub-aerially prior to the Holocene transgression. CHIRP sub-bottom profiles demonstrate that the bulk of the channel-fill sequences consists of one-to-two transparent units. Vibracores indicate that these units are composed of organic muds, ranging from sandy silt to clayey silt, that reflect a quiet water, biologically productive depositional environment such as a coastal embayment. The presence of marine bivalves in the organic mud suggests that these sediments probably accumulated in a coastal embayment connected to the coastal ocean. Poorly-defined, layered reflectors in the CHIRP record that correlate to beach and barrier-spit facies cover the coastal embayment sediments. Because of the range of sand sizes that can occur in beach and barrier-associated deposits and the limited thickness of these units $(<1 \mathrm{~m})$, it is difficult to identify precisely the exact depositional environments where these sands accumulated. Nevertheless, coarse sands that contained organic material and silt were believed to reflect deposition on the landward side of beaches and coastal barriers that may have fronted coastal embayments that developed in the paleochannels. Exposed beach and shoreface settings are too energetic to retain fine grained organic and silt sized sediments. Precise correlation of these units to the CHIRP profiles was difficult as the thickness of the different sand units approached the resolution of the CHIRP profiler. The base of the beach and barrier spit sediments is interpreted as the ravinement unconformity which represents the first regional erosion and reworking of both inter-channel and over-channel deposits in response to transgression. Over the channels, 
this surface also reflects the transition from protected marine and paralic environments open marine deposition.

Lastly, these channel-fill sequences are capped with a sand unit that is exposed at the seafloor. The well-sorted texture of the sand compared to those below suggests that this was a distinct sedimentary unit interpreted to be nearshore marine sands that are currently being reworked by wave and tidal flows. Where the thickness of the surface unit diminishes below the resolution of the CHIRP system, the upper sand unit is indistinguishable from the seafloor.

Channel B, another channel containing a similar transgressive sequence, was not as extensively sampled as Channel A. Despite the limited number of cores acquired from this channel, CHIRP profiles from Channel B reveal a similar internal geometry to that observed in Channel A. These profiles showed that Channel B was eroded in the same glacial outwash unit. A few CHIRP profiles from this channel also showed that a transparent acoustic unit formed the bulk of the channel-fill sequence above the basal channel unconformity. No cores acquired from Channel B penetrated the transparent unit. Like Channel A, the transparent unit is capped by several poorly defined, layered units. A core from one site along this channel penetrated this upper portion of the channel sequence. The lower sedimentary units defined in this core, consisting of a sandy gravel with shell fragments, was interpreted as a beach or barrier deposit. The upper unit, which is comprised of a dark gray gravelly sand contained fluid saturated with fine organic matter. It is difficult to interpret the depositional setting of this unit. These two units could not be correlated precisely to the CHIRP profile of the core site. In spite of this poor correlation, other CHIRP profiles from Channel B exhibit similar stratal patterns to Channel A. Because of the similar CHIRP images between these channels it is probable that these channels accommodate similar stratigraphic sequences.

Channel $\mathrm{C}$, which is not as clearly defined in the CHIRP profiles as Channels $\mathrm{A}$ and $\mathrm{B}$, also exhibited a similar stratigraphic sequence. Where the sequence in this channel is better defined, blurred reflections caused by biogenic gas impede the definition of the lower part of the channel sequence. One core from the northern part of Channel $\mathrm{C}$ penetrated a Holocene sedimentary sequence similar to that sampled in Channel A. Although this core did not penetrate the base of the channel sequence or the channel wall, the position of this feature between Channels $A$ and $B$ suggests that it was seated in a similar substrate to Channels A and B. The sediment in Channel $\mathrm{C}$ also consists mainly of organic silt and a surface sand unit. The base of the core acquired from this channel also 
penetrated peat deposits not present in cores from the other channels. The organic mud in the channel fill differs from the previous two channels, however, in that no marine bivalve remains or foraminifera are encountered in the fine-grained organic silt or peat that is present in the cores. The lack of marine species suggests that this particular sequence may have accumulated in a small back-barrier marsh, which was not in contact with the coastal ocean. Plant fragments, which can be diagnostic of specific marsh types, were not identifiable in the peat at the base of the core obtained from this site. The lower of the sand units overlying the organic mud identified is identified as former beach and barrier deposition. Like other sites, the nearshore marine sand unit, which was not resolved in CHIRP images of the buried channel at the core site, covers the channel sequence.

The two smaller channels (channels imaged in survey lines three and five), located within the western portion of the study site, also exhibit similar channel-fill sequences similar to the previous channels. The internal stratal geometry of the channel sequence is not well-defined in the CHIRP profiles due to the presence of gas reflections in the channels. Cores were able to define the stratigraphy of the channel-fill sequences. Core 11 obtained from a small channel imaged in survey line 3 exhibits a sedimentary sequence that varies slightly from those sampled on the eastern portion of the study area. Sediments at this site consist of marsh and tidal flat deposits, which could have accumulated along the fringe of a coastal embayment or in a tributary feeding a larger coastal embayment. The presence of articulated Mercenaria shells, which appear to have been deposited in-place, support the interpretation that a tidal flat environment occupied this site. Radiocarbon dates of two of these shells, occurring 9.75 and 9.9 meters below present mean sea level, show that these environments existed at this location as much as 3700 B.P. The organic muds are capped by a gravelly sand that is unique to this core. This sand is completely composed of granule-sized clasts (-1-to-(-2) phi) and lies exposed at the seafloor. Tidal inlet and barrier beach sediments were not present in this core.

Finally, core 18 shows a channel-fill sequence more like those of Channel A reflecting accumulation of coastal embayment facies in response to relative sea-level rise. Marine bivalve remains found in the organic silt in this core suggest that the coastal embayment that occupied this site was in contact with the coastal ocean. Despite the presence of a coarse sand unit with shell fragments and gravel, clear evidence of tidal inlet and barrier spit environments is lacking at this site. These deposits may have since been eroded from the upper portions of this unit. 
Together the presence of these sequences reflect the Holocene submergence of the late-Pleistocene landscape on the south shore of Cape Cod. The sedimentary sequences present in Channels $\mathrm{A}, \mathrm{B}$, and $\mathrm{C}$ as well as the smaller channels progressively filled the late-Pleistocene valleys in response to rising relative sea level. The valleys or paleochannels that accommodate these sediments are most likely offshore extensions of the latePleistocene spring sapping valleys that were eroded into the glacial outwash substrate (Uchupi and Oldale, 1994). Cores show that the base of some of the smaller channels are filled with marsh sediments that were vertically replaced by organic mud. In the larger channels, marsh sediments were not encountered, but the cores did not penetrate the base of the channel sequence. These cores indicate that organic muds similar to those in the smaller channels were present. In all of these channels, the organic mud is covered with sand deposits reflecting beach and barrier-spit depositional environments. A modern seafloor sand that is currently being reworked covers the channel-fill sequence in most of the channels.

The sedimentary sequence that accumulated in the paleo-channels indicated that a consistent pattern of coastal embayment and shoreline facies succeeded one another in response to relative sea-level rise. As relative sea-level flooded the paleo-channels, marsh environments were probably established in response to the rising water table. With continued sea-level rise, the marsh environments migrated farther up channel. Eventually, the exposed paleo-channels continued to flood accommodating quiet water coastal embayments, likely protected from wave action by barrier beaches located more seaward. As relative sea-level rise continued, the coastline was driven landward over regions within the paleo-channels that formerly accommodated marsh and embayment sedimentation. The landward migration of the coastline was indicated by beach and barrier facies that covered the fine grained coastal embayment sediments. With further relative sea-level rise, beach and barrier settings were truncated as the shoreface migrated farther landward and nearshore marine deposition by wave and tidal flows ensued.

Based on relative sea-level estimations gathered from southeastern Massachusetts, these channels probably began to flood between 6000 and 7000 years B.P. The use of published relative sea-level estimates show that the deepest portions of Channel A, which occur 16.5 meters below present mean sea level probably began to flood at this time (Fig. 39). Two radiocarbon age estimates obtained in this study fall close to the age estimates collected in these other studies. Radiocarbon ages from in place, articulated Mercenaria, sampled from a depth of 9.75 and 9.9 meters, yielded radiocarbon ages of $3790 \pm 70$ years 
B.P. and $3640 \pm 90$ years B.P. respectively. The close vertical proximity of these dates and the age error overlap suggests that these two samples are coeval. Since these two specimens were most likely deposited in an intertidal environment in a microtidal setting these estimates correlate reasonably well to other relative sea-level estimates from this area. Forthcoming radiocarbon age estimates that are being processed at the Woods Hole Oceanographic Institution NOSAMS facility will help to put the accumulation of the deposits in Channels A, C, and the smaller channels in context of the relative sea-level history in this region.

Modern coastal embayments present on the south shore of Cape Cod provide an analog to the depositional environments recorded in channel-fill sequences from offshore channels. Marshes occur on the landward portions and along the fringes of coastal embayments present in Popponesset Bay, Cotuit Bay, and West Bay, onshore of the study site. The bays themselves accommodate the accumulation of fine-grained organic muds and sands. The shoreward portions of these bays are separated from the ocean by barrier beaches and barrier spits. Tidal inlets connect these embayments to the coastal ocean. The presence of these depositional environments on the present-day coastline and in buried offshore channels further indicates that as relative sea-level has risen these environments have migrated up-gradient in the formerly exposed paleo-channels.

The transgressive systems tract recorded in channels A, B, and C as well as the smaller channels is similar to other transgressive sequences that have accumulated along the New England and northern Mid-Atlantic coasts of the United States during the mid-to-late Holocene. Similar sequences consisting of marsh and lagoonal or estuarine sediments capped by shoreface and tidal inlet sediments that have accumulated over formerly exposed late-Pleistocene topographic lows have been identified off the coast of Delaware and New York (Rampino and Sanders, 1980a; Belknap and Kraft, 1985). In addition, modern sequences of lagoonal and marsh deposits cored in Connecticut, Delaware, Rhode Island and Maine exhibit similar sedimentary successions that have accumulated in present-day coastal embayments (Dillon, 1970; Boothroyd et al., 1982; Duffy et al., 1989).

Sedimentary sequences identified at these sites showed that laterally situated depositional environments consisting of marsh, lagoonal/estuarine, and barrier related facies succeed one another in vertical sequences that were being eroded and buried in offshore regions. 


\section{B. Glaciolacustrine Channel-Fill Sequence}

A sedimentary sequence different from those sampled in Channels A, B, C and the smaller channels, was encountered in the Trunk Channel and Channel E. CHIRP profiles show that the bulk of this channel sequence is stratigraphically lower than the sequences recorded in Channels A, B, C and the two smaller channels. Two cores from the Trunk Channel penetrated channel-fill sediments that consist of three sedimentary units. The basal units are comprised of a homogeneous silt and clayey silt that lack organic matter or fossils. These sediments are interpreted as late-Pleistocene glaciolacustrine sediments based on core descriptions from O'Hara and Oldale (1987) despite the presence of glauconite, a marine authigenic mineral. Varves, if present, were probably destroyed during post-acquisition core handling as the silty sediments liquified upon disturbance. Glauconite is thought to have been incorporated in these sediments through the reworking of Tertiary Coastal Plain sediments by glacial processes. The upper portion of the silt unit was thought to have been exposed to the atmosphere, based on the presence of reddish discolorations at the surface of the unit reflecting the oxidation of otherwise dark gray, reduced sediments. This boundary could record the draining of the lake glacial lake where these deposits accumulated. This upper boundary forms an unconformity separating the silt from two overlying sand units. This surface corresponds to both the transgressive surface and the ravinement surface representing the regional erosion of this region in response to relative sea-level rise. The lower sand is interpreted as a beach deposit which was eroded into the silt below. The upper sand unit is believed to be modern seafloor sand that is currently being reworked and re-deposited today.

A similar sedimentary sequence is present in one core acquired from Channel $\mathrm{E}$. This core penetrated a silt unit identical to the one encountered in cores 13 and 14. The upper portion of this silt unit is also brownish indicating oxidation due to sub-aerial exposure. Two sand units also cap the silt unit that formed the bulk of this core. The lower sand unit consists of a beach sand and gravel different from that covering the silt in cores from the Trunk Channel. This sand contains shell fragments and gravel like the other sand unit but is darker in color due to staining from abundant fine organic material on the sand grains. This unit is replaced by an organic stained, well-sorted medium sand similar to the surface sand units encountered in other cores. This sand unit, like the others, is interpreted as a nearshore sand unit that is currently being reworked. The boundary between the two sand units is subtle, noted primarily by a change in sand sorting. 
These sedimentary units, defined in the Trunk Channel and Channel E, are thought to be Pleistocene glacial lake deposits that are capped by the late-Holocene transgressive systems tract. The silt that forms the base of the sampled sequences is similar to the latePleistocene glacial lake sediments described in cores obtained by O'Hara and Oldale (1987). Correlating these silt units to CHIRP images of the channels show that the bulk of the channel-fill sequence consists of the late Pleistocene glaciolacustrine silt and clay deposits. The transgressive systems tract in these channels is limited to the upper portion of the channel sequence, consisting of the two sand units that cover the silt deposits. These sand units consist of beach and shoreline sands that are covered with nearshore marine sands reflecting the migration and erosion of the shoreline driven by relative sea-level rise.

\section{Implications for the Geological Evolution of the South Shore of Cape Cod}

The presence of two different channel-fill sequences indicate that portions of the channel network defined off the south shore of Cape Cod, Massachusetts are not related. Alternatively, the channels may be related in their formation; however, the infilling of the channels is quite different. Channels A, B, C, and two small channels, which are probably offshore extensions of groundwater sapping channels eroded into the late-Pleistocene glacial outwash plains, are filled with Holocene transgressive systems tracts. These systems tracts recorded the formation and offshore burial of marsh and coastal embayment environments that formed landward of the shoreline as the topographic lows formed by paleo-sapping channels were flooded. The other channel-fill sequence, which fills the Trunk Channel and Channel E, consists of late-Pleistocene glaciolacustrine deposits which are unconformably covered by a Holocene transgressive systems tract comprised of beach and modern nearshore sands. The oxidized upper boundary of the glaciolacustrine fill in the Trunk Channel and Channel E suggests that deposition of the this sedimentary unit preceded the Holocene submergence and transgressive erosion of this channel. The reddish brown color of the otherwise gray sediments suggests that these deposits were probably exposed to the atmosphere prior to submergence. The limited thickness the transgressive systems tract in the Trunk Channel and Channel E relative to the other channels shows that these channels probably did not accommodate coastal embayments or protected depositional settings during transgression. The rate of sea-level rise at this time or differences in the orientation and the size of these channels may have inhibited the formation and/or preservation of these environments. 
Because the basal substrate in the channels filled with glaciolacustrine sediments was not penetrated by vibracores, the origin of these channels is not clearly known. The channels that contain these deposits are almost two to three times the width of the spring sapping channels. The depth of these channels approaching 21 meters below present mean sea-level is too shallow to associate them with pre-glacial Tertiary coastal plain deposits, whose upper occurrences are 30 to 40 meters below present mean sea-level (O'Hara and Oldale, 1987). Since late Pleistocene glaciolacustrine sediments fill these channels and that the lower acoustic unit that contains these channels is overlain by glacial outwash sediments, this lower acoustic unit is probably composed of a marginal glacial lake deposit or fine-grained outwash plain sediments that were deposited far from the ice source on the distal portions of an outwash deposit. Work in Alaska, that has been related to ice-margin deposits in New England, showed that a highly variable array of deposits can occur along the margins of ice sheets during glacial melting and retreat (Gustavson and Boothroyd, 1987).

At this setting, the upper acoustic unit probably represents the offshore extension of the Barnstable outwash plain. The lower acoustic unit could represent either glaciolacustrine sediments or distal portions of the Mashpee Pitted Plain, an outwash plain that preceded the formation of the Barnstable Plain. Groundwater sapping channels traced in the onshore portions of the Mashpee Pitted Plain indicate that the eastern portions of the outwash plain dip to the southeast towards this study area. Since the Mashpee Pitted Plain predates the Barnstable Plain, distal portions portions of the former deposit are probably overlain by the younger Barnstable Plain along the margin between the two units. Meltwater from the younger Barnstable Plain may have eroded the large valleys (Trunk Channel and Channel E) into the lower acoustic unit forming the large channels (here defined as distal portions of the Mashpee Pitted Plain) and later filled with glacial run-off that pooled in the depressions depositing fine-grained sediment. Another possibility is that the lower acoustic unit is a glacial lake deposit, which is overlain to the north by the offshore portions of the Barnstable Plain, whose outwash deltas may have prograded over the marginal lake deposits. These lake deposits may have been incised by meltwater flow from the outwash plains and later filled with fine-grained sediments that could have pooled in the depressions. Either way, the Trunk Channel and Channel E are filled with glaciolacustrine sediments. Still, it remains unclear if these glacial lake deposits are remnants of the glacial lake that existed in this region or if they are reworked glacial sediments that accumulated in standing water at the edge of outwash plains. More 
geophysical data correlated to deeper penetrating cores from the channels and inter-channel regions are needed to confirm and better test the observations and interpretations made in the present study.

Despite different channel-fill between the filled sapping channels and the larger Trunk Channel and Channel E, these channels appear to form a spatially-linked channel network. Since the Trunk Channel forms a central feature that is fed by all of the paleochannels defined in the study area, this channel may have exerted a structural control on the surface flow of water discharged from spring sapping channels in this area. The topographic highs to the south of the large east-west trending low could have also formed a structural barrier controlling the flow of the run-off from spring sapping. Thus, the channel could have formed a collection area for the flow of water from spring sapping channels. This flow may have eroded the upper portions of the glaciolacustrine sediments that filled the Trunk Channel as the water collected a flowed to the southwest into Vineyard Sound. Therefore, the lake deposits in the Trunk Channel could have been differentially eroded compared to those Channel $\mathrm{E}$. This hypothesis could explain the difference in thickness between the deposits in Channel E and the Trunk Channel (11 meters vs. 6 meters respectively according to CHIRP records), which both extend 19-to-21 meters at most below present mean sea-level. In order to make this hypothesis viable, it would also be expected that some sort of fluvial deposit would exist in the channel-fill sequences in these channels, yet none was indicated in either cores or CHIRP records of the Trunk Channel or Channel E. Prior to the formation of the sapping channels, it appears that these deposits remained exposed sub-aerially until they were eroded further during transgression. Based on the relative sea-level curve from Vineyard Sound (Oldale and O'Hara, 1980), this may have occurred around 7000 B.P.

Work on the southern coast of Connecticut along Long Island Sound, has linked the formation of paleo-valleys that accommodate modern-day marshes to spring sapping in late-Pleistocene glacial sediments (Gehrels and Van de Plassche, 1991). The sapping channel network that encloses Hammock River marsh was eroded into a combination of glacial outwash, glaciolacustrine, and lake-margin deltaic deposits and was also structurally influenced by glacial moraines that are present along the present coastline of this region. The channels that formed at this site have filled with modern marsh sequences in response to relative sea-level rise during the Holocene (Van de Plassche et al., 1992). At the Connecticut site, researchers were better able to define the stratigraphic architecture of the late-Pleistocene sapping channels based on sediment cores than in the present study. At the 
Cape Cod site presented in this study, no evidence of along-network variations in sediment fill related to the late-Pleistocene channels could be defined.

\section{Conclusions}

Findings from this study show that two different channel-fill sequences, part of which record the Holocene transgression, have accumulated in the channel system off of the south shore of Cape Cod. One channel sequence, encountered in the Trunk Channel and Channel E, consists of late-Pleistocene glaciolacustrine silt and clay capped by two Holocene sand units. The other sequence, which occupies the upper portions of the channel network (Channels A, B, C and the two smaller channels), is comprised of Holocene marsh, coastal embayment, and shoreline deposits. CHIRP sub-bottom profiles indicate that the former channels were eroded into an undefined glacial unit that lies below glacial outwash deposits that contain the other channels, suggesting that the two channels can also be distinguished based on their stratigraphic position.

The different manifestations of the transgressive systems tract in the two channel systems show that channel size and orientation as well as the rate of relative sea-level rise may have controlled the occurrence of different coastal depositional environments in the past. The transgressive deposits in the Trunk Channel and Channel E record only shoreface and nearshore sedimentary environments. Channels A, B, C, and the two smaller channels record the progressive submergence and development of protected coastal embayments in the upper portions of the channel network. This difference can be related to several variables. First, the Trunk Channel and Channel E were filled prior to the submergence of this region by processes independent of changes in base level (glaciolacustrine sedimentation), leaving a relatively limited amount of space to accommodate sediments during transgression. Secondly, the size difference between the channels accommodating the two channel-fill types probably contributed to large preservation potential differences between the two channel types during the Holocene transgression. Lastly, the rate of relative sea-level rise, which has decreased steadily towards the present, may have also contributed to differences between to two channeltypes.

Findings also show that the sedimentary sequences that have accumulated in Channel A, B, C and the two smaller channels are offshore extensions of coastal environments that persist on the south shore of Cape Cod at the present time. The sequence that fills Channels $\mathrm{A}, \mathrm{B}, \mathrm{C}$, and two smaller channels (coinciding with survey 
lines three and five) is composed of a transgressive systems tract comprised of marsh, coastal embayment, and shoreline sands. These sequences were deposited seaward of the present shoreline when valleys cut by the paleo-spring sapping channels were progressively filled in response to relative sea-level rise. Based on correlations to relative sea-level dates collected in Vineyard Sound and Buzzards Bay, the sequences in these channels have been accumulating during the last 6000 to 7000 years. Additional radiocarbon dates, which are forthcoming, will help to better constrain the time scale over which these sequences have accumulated. In addition, stable carbon isotope results from the marsh peats that were submitted for radiocarbon dating will provide information concerning the source of the organic sediments from these channels allowing for more precise comparisons between the offshore deposits and the modern coastal embayments on this shoreline. 


\section{References}

Bard, E., Hamelin, B., Fairbanks, R.G., and Zindler, A., 1990. Calibration of the C-14 timescale over the past 30,000 years using mass spectrometric U-Th ages from Barbados corals. Nature, 345, 405-410.

Belknap, D.F. and Kraft., J.C., 1985. Influence of antecedent geology on stratigraphic preservation potential and evolution of Delaware's barrier systems. Marine Geology, 63, 235-262.

Bloom, A.L. and Stuiver, M., 1963. Submergence of the Connecticut coast. Science, 139, 332-334.

Boothroyd, J.C., Freidrich, N.E., and McGinn, S.R., 1985. Geology of microtidal coastal lagoons: Rhode Island. Marine Geology, 63, 35-76.

Boyd, R., Bowen, A.J., and Hall, R.K., 1987. An evolutionary model for transgressive sedimentation on the eastern shore of Nova Scotia. In: Glaciated Coasts, Fitzgerald, D.M. and Rosen, P.S. (Eds.), Academic Press, Inc, London. 364 pp.

Carter, R.W.G, Forbes, D.L., Jennings, S.C., Orford, J.D., Shaw, J., and Taylor, R. B., 1989. Barrier and lagoon coast evolution under differing relative sea-level regimes: examples from Ireland and Nova Scotia. Marine Geology, 88, 221-242.

Chmura, G.L., Aharon, P., Socki, R.A., and Abernethy, R., 1987. An inventory of C13 abundances in coastal wetlands of Louisiana, USA: vegetation and sediments. Oecologia, 74, 264-271.

Christie-Blick, N. and Drsicoll, N.W., 1995. Sequence stratigraphy. Annual Reviews Earth and Planetary Science, 23, 451-478.

Demarest, J.M. and Kraft, J.C., 1987. Stratigraphic record of Quaternary sea levels: implications for more ancient strata. In: D. Nummedal, O.H. Pilkey, and J.D. Howard (Eds.), Sea-Level Fluctuation and Coastal Evolution, SEPM Spec. Pub. $41,129-143$.

Dillon, W.P, 1970. Submergence effects on a Rhode Island barrier and lagoon and interferences on migration of barriers. Journaly of Geology, 78, 94-106.

Driscoll, N. and Uchupi, E., 1997. The importance of gas and groundwater seepage in landscape and seascape evolution. Thalassas, 13, 35-48.

Duffy, W., Belknap, D.F., and Kelley, J.T., 1989. Morphology and stratigraphy of small barrier-lagoon systems in Maine. Marine Geology, 88, 243-262.

Emery, K.O. and Uchupi, E., 1984. Geology of the Atlantic Ocean. Springer-Verlag, New York, 1050 pp. 
Emery, K. O. and Aubrey, D.G., 1991. Sea levels, land levels, and tide gauges. SpringerVerlag, New York, 237 pp.

EdgeTech, 1997. Technical and user's manual for the X-Star full spectrum sub-bottom profiler. EdgeTech, Milford, Massachusetts, $140 \mathrm{pp}$.

Fairbanks, R.G., 1989. A 17,000-year glacio-eustatic sea level record: influence of glacial melting rates on the Younger Dryas event and deep ocean circulation. Nature, 342 , 637-642.

Fitzgerald, D.M., 1993. Origin and stability of tidal inlets in Massachusetts. In: Formation and Evolution of Multiple Tidal Inlets, Aubrey, D.G. and Giese, G.S.(Eds.). Coastal and Estuarine Studies (44), American Geophysical Union, Washington, D.C., 1-61.

Foreman, M.G.G., 1977. Manual for tidal heights analysis and prediction. Pacific Marine Science Report 77-10, Institute of Ocean Sciences, Patricia Bay, Sidney, B.C., 97 pp.

Gehrels, W.R., 1994. Determining relative sea-level change from salt-marsh foraminifera and plant zones on the coast of Maine, U.S.A., Journal of Coastal Research, 10, 4, 990-1009.

Gehrels, W.R. and van de Plassche, O., 1991. Origin of the paleovalley system underlying Hammock River Marsh, Clinton, Connecticut. Journal of Coastal Research, Special Issue $11,73-83$.

Gehrels, W.R. and Belknap, D. F., 1993. Neotectonic history of eastern Maine evaluated from historic sea-level data and C-14 dates on salt marsh peats. Geology, 21, 615618.

Gehrels, W.R., Belknap, D.F., and Kelley, J.T., 1996. Integrated high-precision analysis of Holocene relative sea-level changes: lessons from the coast of Maine. G.S.A. Bulletin, 108, 9, 1073-1088.

Gustavson, T.C. and Boothroyd, J.C., 1987. A depositional model for outwash, sediment sources, and hydrologic characteristics, Malaspina Glacier, Alaska: a modern analog of the southeastern margin of the Laurentide Ice Sheet. G.S.A Bulletin, 99, 187-200.

Jennings, S.C., Carter, R.W.G, and Orford, J.D., 1993. Late Holocene salt marsh development under a regime of rapid sea-level rise: Chezzetcook Inlet, Nova Scotia. Implications for the interpretation of palaeomarsh sequences. Canadian Journal of Earth Science, 30, 1374-1384.

Kiden, P., 1995. Holocene relative sea-level change and crustal movement in the southwestern Netherlands. Marine Geology, 124, 21-41.

Kjerfve, B. and Magill, K.E., 1989. Geographic and hydrodynamic characteristics of shallow coastal lagoons. Marine Geology, 88, 3/4, 187-199. 
Kraft, J.C., 1971. Sedimentary environment facies patterns and the geologic history of a Holocene marine transgression. G.S.A. Bulletin, v. 82, 2131-2158.

Kraft, J.C., 1978. Coastal stratigraphic sequences. In: R.A. Davis (Editor), Coastal Sedimentary Environments, Springer-Verlag, New York, 361-383.

Milliman, J.D., and Emery, K.O., 1968. Sea-levels during the past 35,000 years. Science, 162, 3858, 1121-1123.

Nummedal, D. and Swift, D.J.P., 1987, Transgressive stratigraphy at sequence bounding unconformities: some principles derived from Holocene and Cretaceous examples. In: D. Nummedal, O.H. Pilkey, and J.D. Howard (Eds.), Sea-Level Fluctuation and Coastal Evolution, SEPM Spec. Pub. 41, 241-260.

Nydick, K.R., Bidwell, A.B., Thomas, E., and Varekamp, J.C., 1995. A sea-level rise curve from Guilford, Connecticut, USA. Marine Geology, 124, 137-159.

O'Hara, C.J., and Oldale, R.N., 1987. Maps showing geology, shallow structure, and bedform morphology of Nantucket Sound, Massachusetts. U.S. Geological Survey Miscellaneous Field Studies Map MF-1911, 4 sheets.

Oldale, R.N., 1982. Pleistocene stratigraphy of Nantucket, Martha's Vineyard, the Elizabeth Islands, and Cape Cod, Massachusetts. In: Larson G.J. and Stone, B.D., (Eds.), Late-Wisconsinan glaciation of New England: Dubuque, Iowa, Kendall Hunt, 1-34.

Oldale, R. N., 1985. Late quaternary sea-level history of New England: a review of the published sea-level data. Northeastern Geology, v. 7, 192-200.

Oldale, R.N., 1992, Cape Cod and the islands: the geologic story. Parnassus Imprints, East Orleans, Massachusetts, 208 pp.

Oldale, R.N. and O'Hara, C. J., 1980. New radiocarbon dates from the inner continental shelf off southeastern Massachusetts and a local sea-level-rise curve for the past 12,000 yr. Geology, 8, 102-106.

Oldale, R.N. and O'Hara, C. J., 1984. Glaciotectonic origin of the Massachusetts coastal end moraines and a fluctuating late Wisconsinan ice margin. G.S.A. Bulletin, 95, 61-74.

Pizzuto, J.E. and Rogers, E.W., 1992. The Holocene history and stratigraphy of palustrine and estuarine wetland deposits of central Delaware. Journal of Coastal Reserach, 8, 4, 854-867.

Rampino, M.R., and Sanders, J.E., 1980a. Episodic growth of Holocene tidal marshes in the northeastern United States: A possible indicator of eustatic sea-level fluctuations. Geology, 9, 63-67.

Rampino, M.R. and Sanders, J.E., 1980b. Holocene transgression in south-central Long Island, New York. Journal of Sedimentary Petrology, 50, 4, 1063-1080. 
Redfield, A.C. and Rubin, M., 1962, The age of salt marsh peat and its relation to recent changes in sea level at Barnstable, Massachusetts. Proc. Natl. Acad. Sci., 48, $1728-1735$.

Redfield, A.C., 1980. The tides of the waters of New England and New York. William S. Sullwold Publishing, Inc., Taunton, MA. 108 p.

Strahler, A.N., 1966. A geologist view of Cape Cod: Garden City, New York Natural History Press, 115 pp.

Swift, D.J.P., 1968. Coastal erosion and transgressive stratigraphy, Journal of Geology, $76,444-456$.

Thomas, E. and Varekamp, J.C., 1991. Paleo-environmental analyses of marsh sequences (Clinton, Connecticut): evidence for punctuated rise in relative sea level during the latest Holocene. Journal of Coastal Research Spec. Issue 11, 125-158.

Uchupi, E. and Oldale, R.N., 1994. Spring sapping origin of the relict valleys of Cape Cod and Martha's Vineyard and Nantucket Islands, Massachusetts. Geomorphology, 9, 83-95.

Uchupi, E., Giese, G.S., Aubrey, D.G., and Kim, D.J. 1996. The late quaternary construction of Cape Cod, Massachusetts: a reconsideration of the W. M. Davis model. G.S.A. Spec. pap. 309, 69 pp.

Van Heteren, S. and van de Plassche, O., 1997. Influence of relative sea-level change and tidal-inlet development on barrier spit stratigraphy, Sandy Neck, Massachusetts. Journal of Sedimentary Research, 67, 2, 350-363.

Van de Plassche, O., 1986. A Manual for the Collection and Evaluation of Data. Norwich, U.K.: Geo Books, 618 pp.

Van de Plassche, O. 1991. Late holocene sea-level fluctuations on the shore of Connecticut inferred from transgressive and regressive overlap boundaries in salt-marsh deposits. Journal of Coastal Research, Spec. Issue 11, 159-179.

Van de Plassche, O., van Heteren, S., Gehrels, W.R., and Mook, W.G., 1992. Waterlevel changes in the Hammock River marsh paleovalley, Connecticut between 13,000 and 6000 (C-14) yrs B.P. Sedimentary Geology, 80, 247-260.

Van Wagoner, J.C., Posamentier, H.W., Mitchum, R.M., Vail, P.R, Sarg, J.F., Loutit, T.S., and Hardenbol, J., 1988. An overview of the fundamentals of seqeunce stratigraphy and key definitions. In: Wilgus, C.K., Hastings, B.S, Kendall, C.G.St. C., Posamentier, H.W., Ross, C.A., and Van Wagoner, J.C. (Eds.), Sea-level changes: an integrated approach, SEPM Spec. Pub. 42, 39-45.

Woodworth, J.B., 1934. Geology of cape Cod and the Islands, in Woodworth, J.B., and Wigglesworth, E., eds., Geography and Geology of the region including Cape Cod, the Elizabeth Islands, Nantucket, Marthas Vineyard, No Mans Land, and Block Island: Memoir, Museum of Comparative Zoology, 52, 237-322. 


\section{FIGURES}




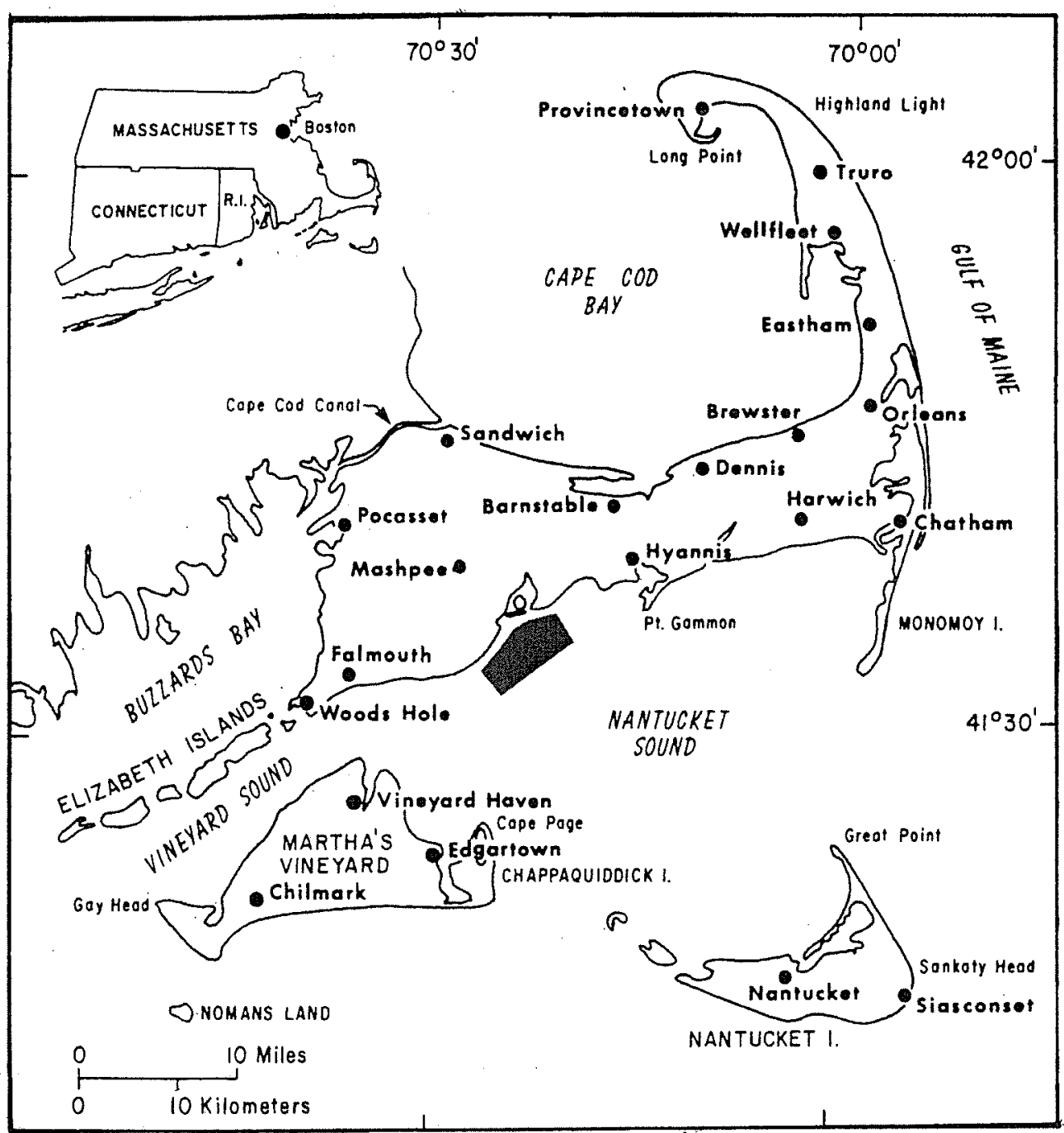

Figure 1. Location map showing the study site off the south shore of Cape Cod, Massachusetts (After Oldale, 1992). Shaded region indicates study site. 


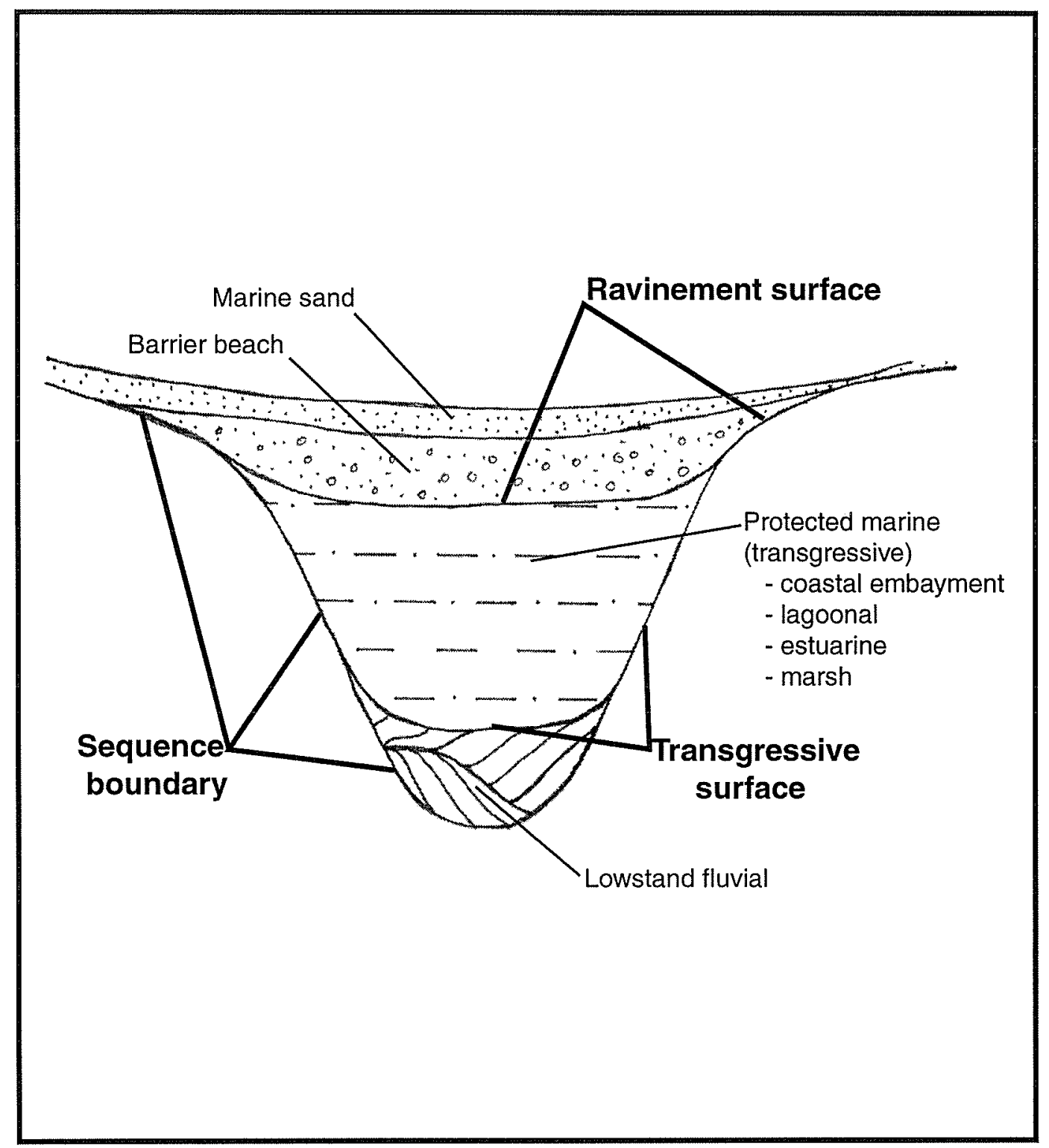

Figure 2. Three stratigraphic boundaries occur typically in transgressive channel-fill sequences. In channels or depressions in the lowstand substrate the sequence boundary, the transgressive surface, and the ravinement surface diverge. In these situations channels can accommodate transgressive sequences that accumulate as relative sea-level rises. Over inter-channel areas and over the upper portions of the channel wall, these boundaries coalesce. 
Figure 3. (Following page) Location of track-lines for the bathymetric and sub-bottom survey. 


\section{Popponesset Study Area}

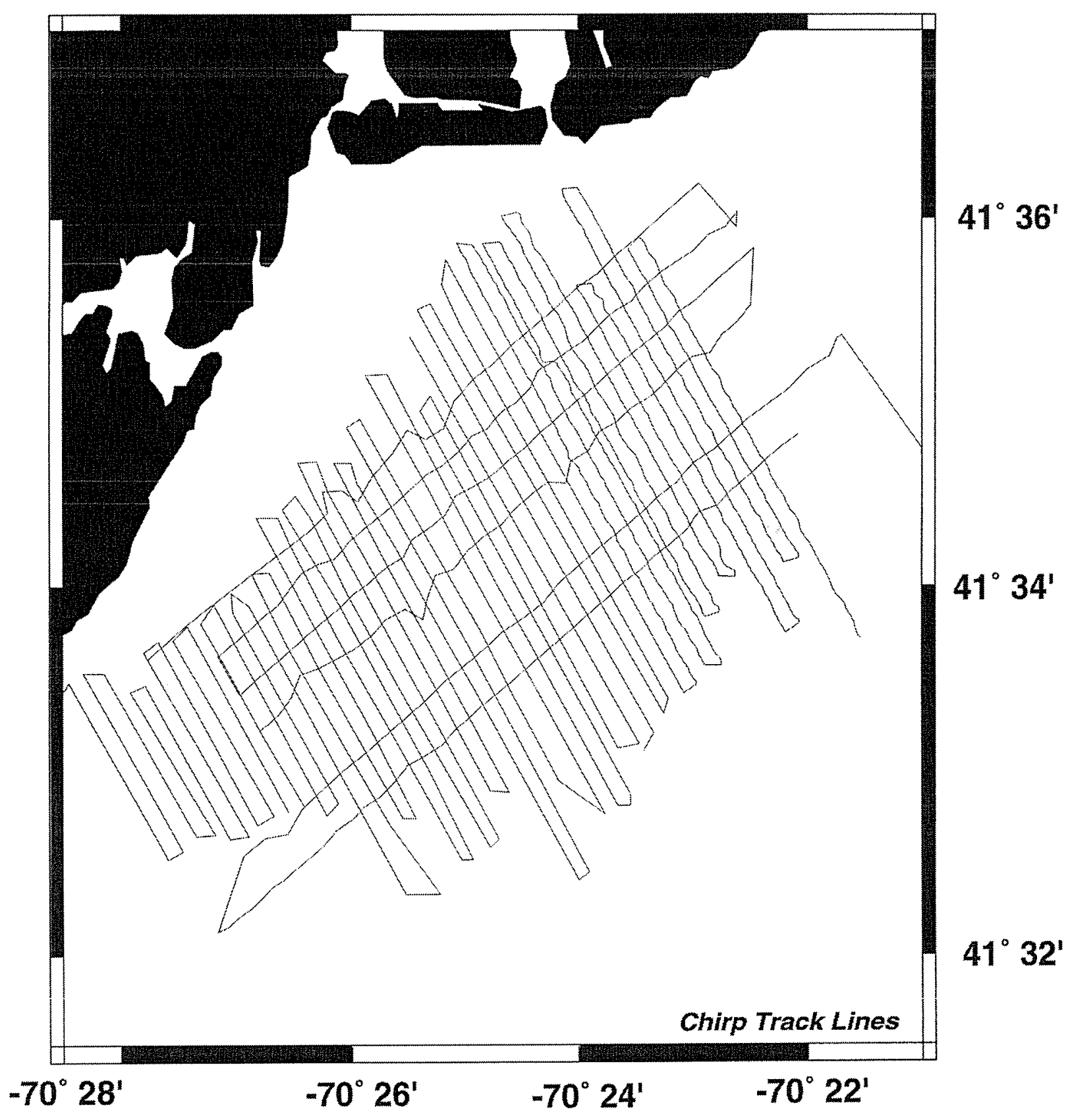




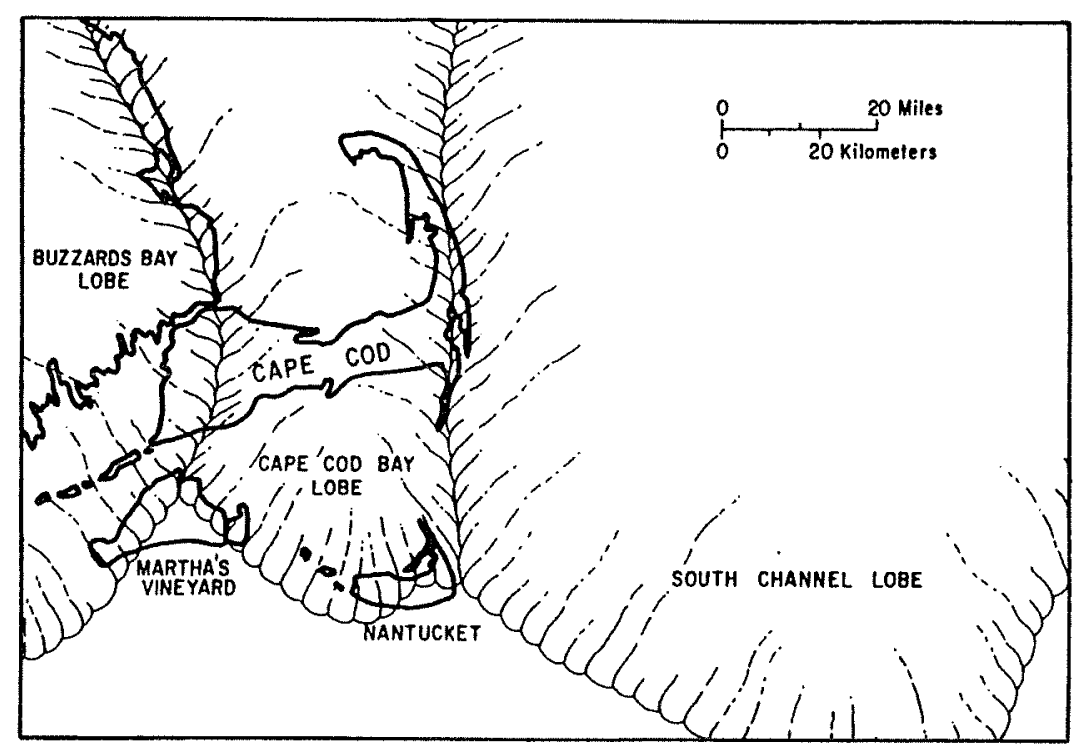

Figure 4. Schematic showing the extent of the three ice lobes which contributed to the formation of CapeCod (From Oldale, 1992). 


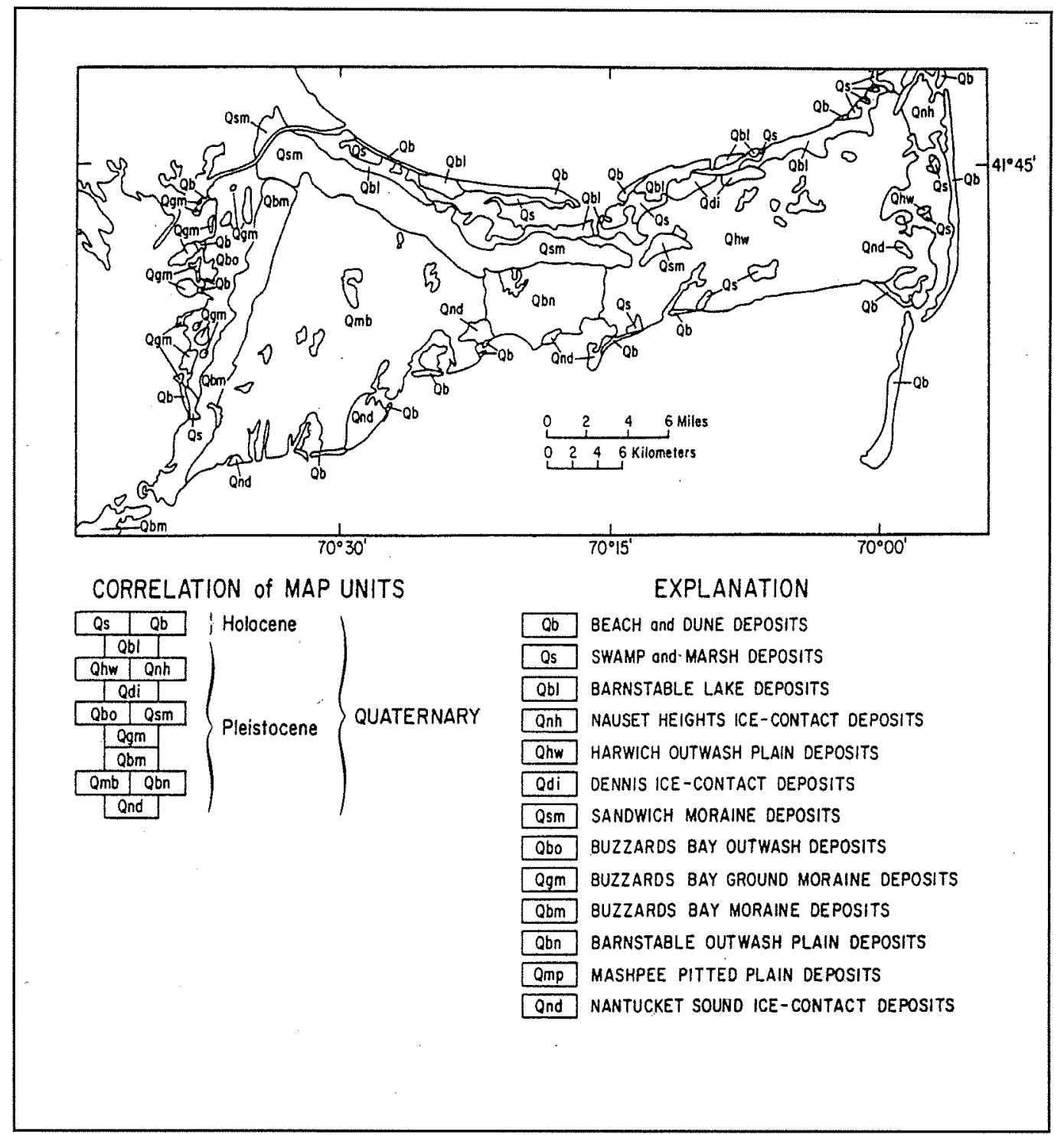

Figure 5. Geologic map showing the distribution of glacial deposits along upper Cape Cod (From Oldale, 1982). 


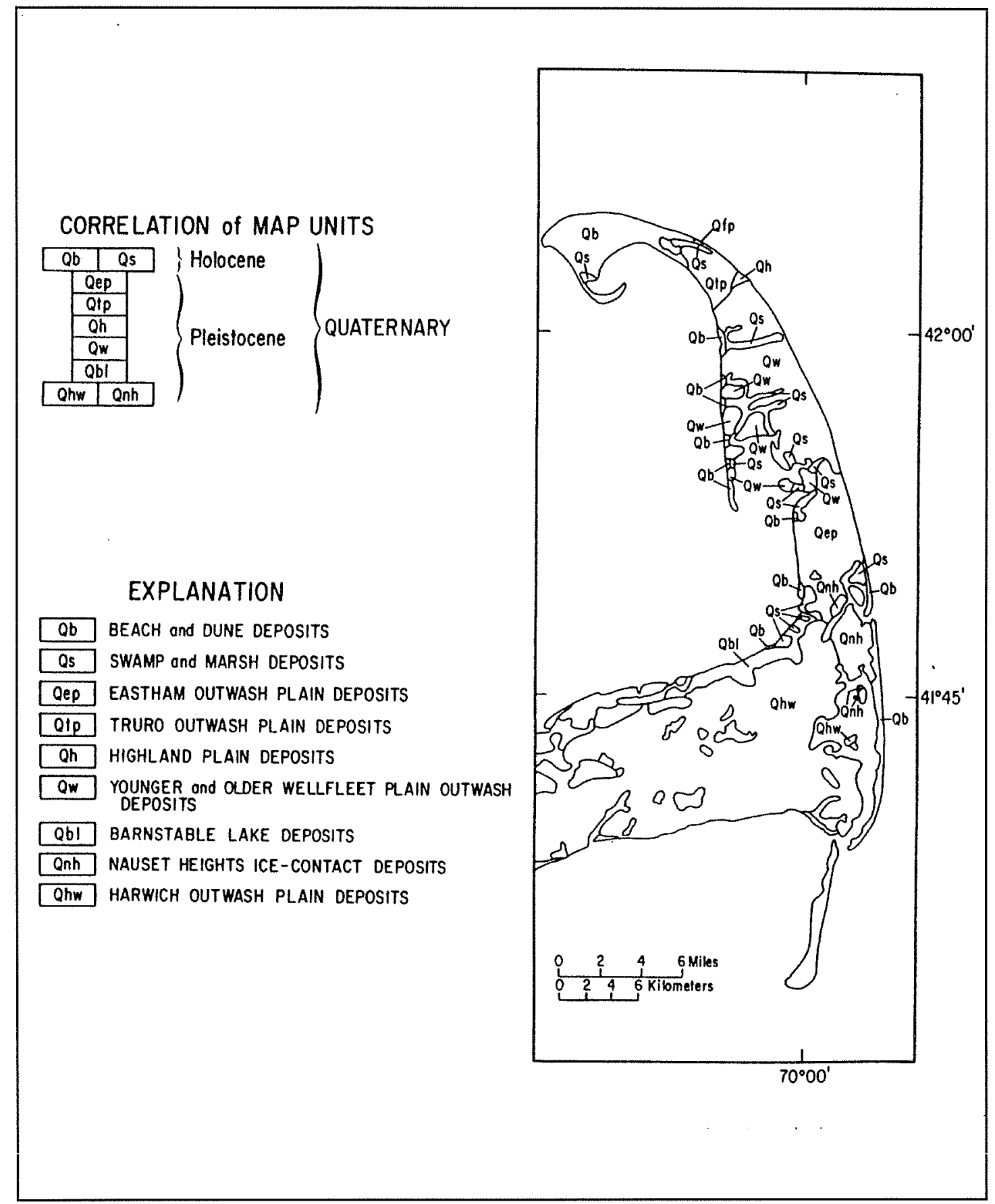

Figure 6. Geologic map showing surficial deposits on the outer portion of Cape Cod (From Oldale, 1982.) 


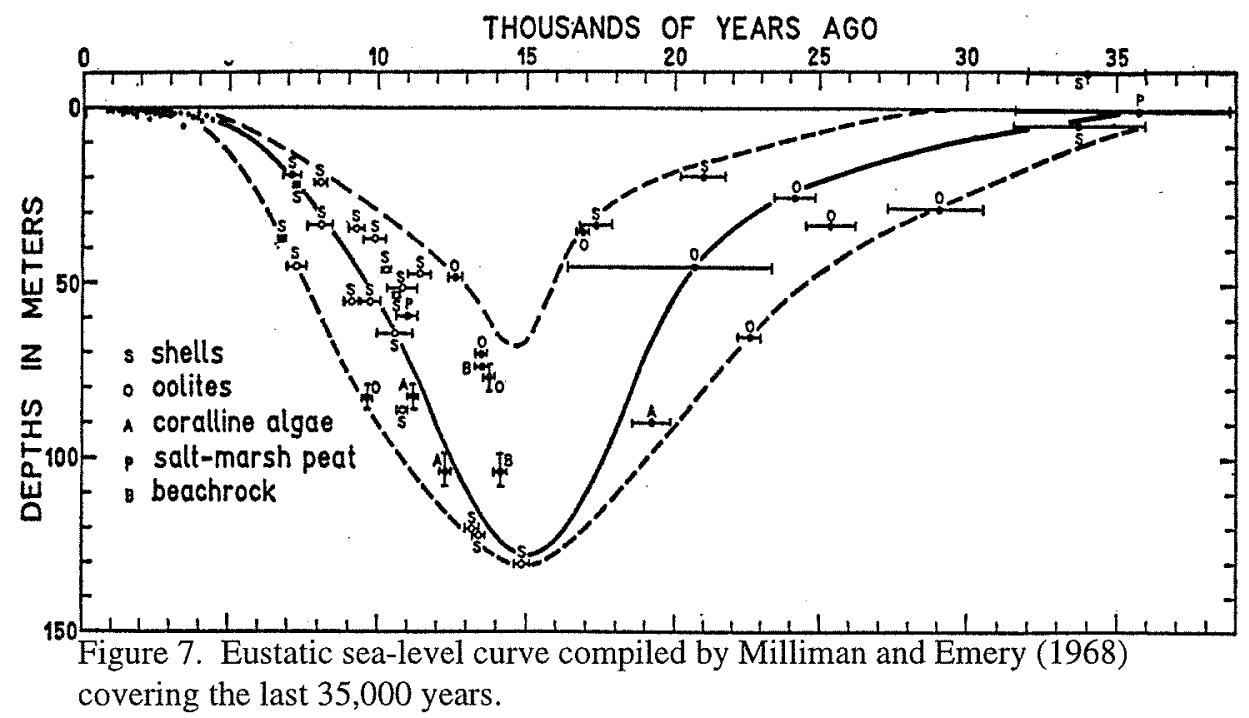




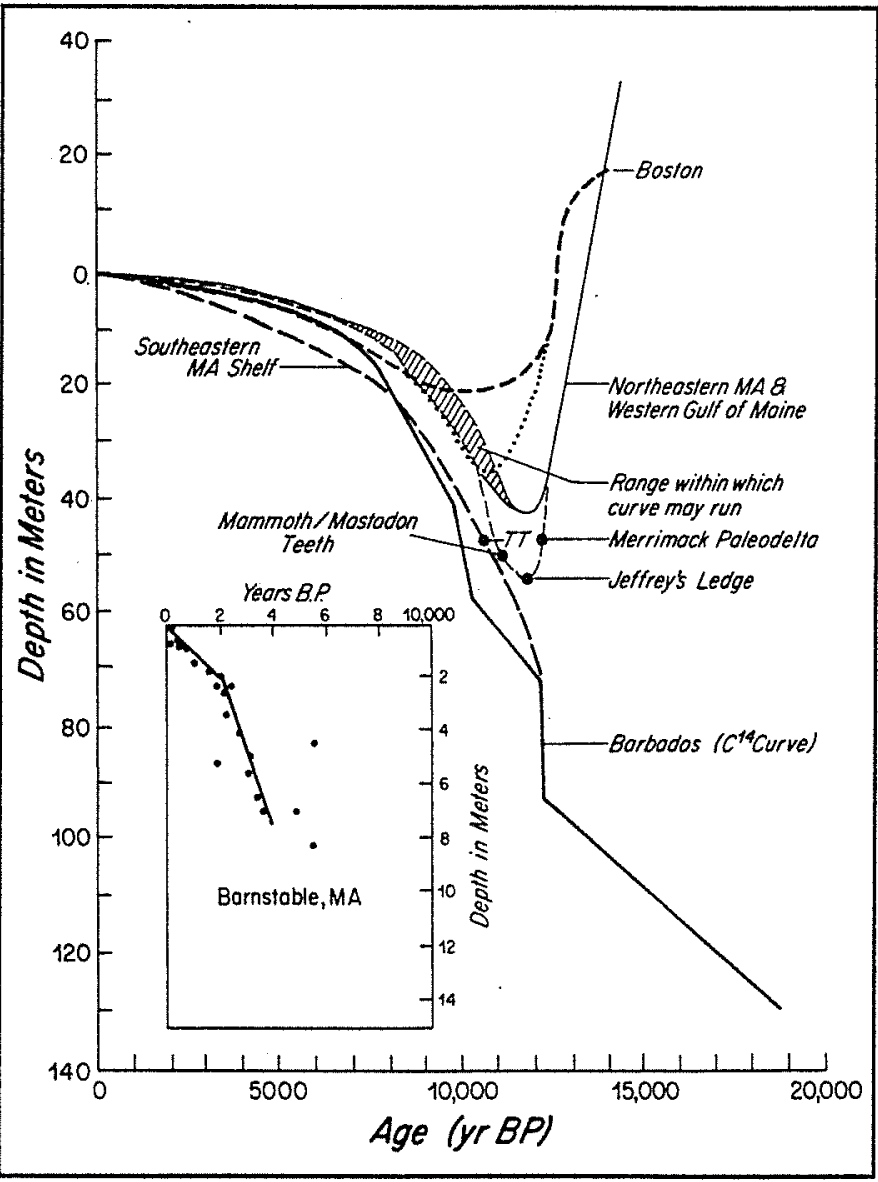

Figure 8. Eustatic sea level compiled by Fairbanks (1989) in comparison to relative sea-level curves from several sites in New England. The differences between the eustatic curve and the New England curves is thought to be caused by glacial unloading. The curve to the lower left is based on salt marsh peat C-14 dates from Barnstable marsh on Cape Cod. This record covers the last 4,000 years (Redfield and Rubin, 1962). (From Uchupi, et al., 1996). 
Figure 9. (Following page) Map of the paleo-channels that were imaged of the south shore of Cape Cod. Solid black lines indicate portions of the channel network where channels could clearly be linked based on the CHIRP profiles. Dotted lines show regions where CHIRP images were not as clear but still delineated the presence of channels. Dotted areas were also inferred from maps from O'Hara and Oldale (1987). The sites of several of the CHIRP profiles that are shown in this study are also included in this map. 


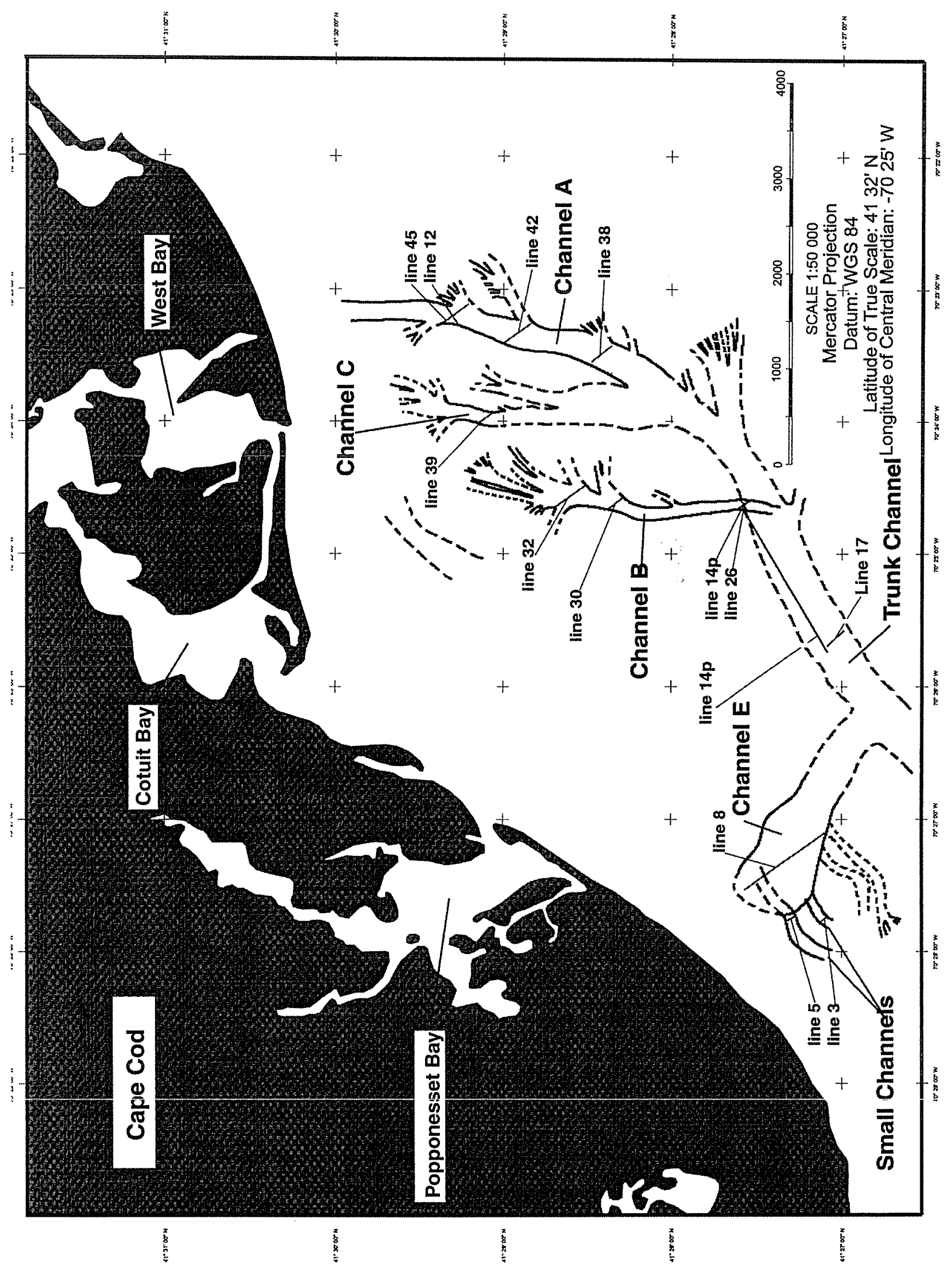



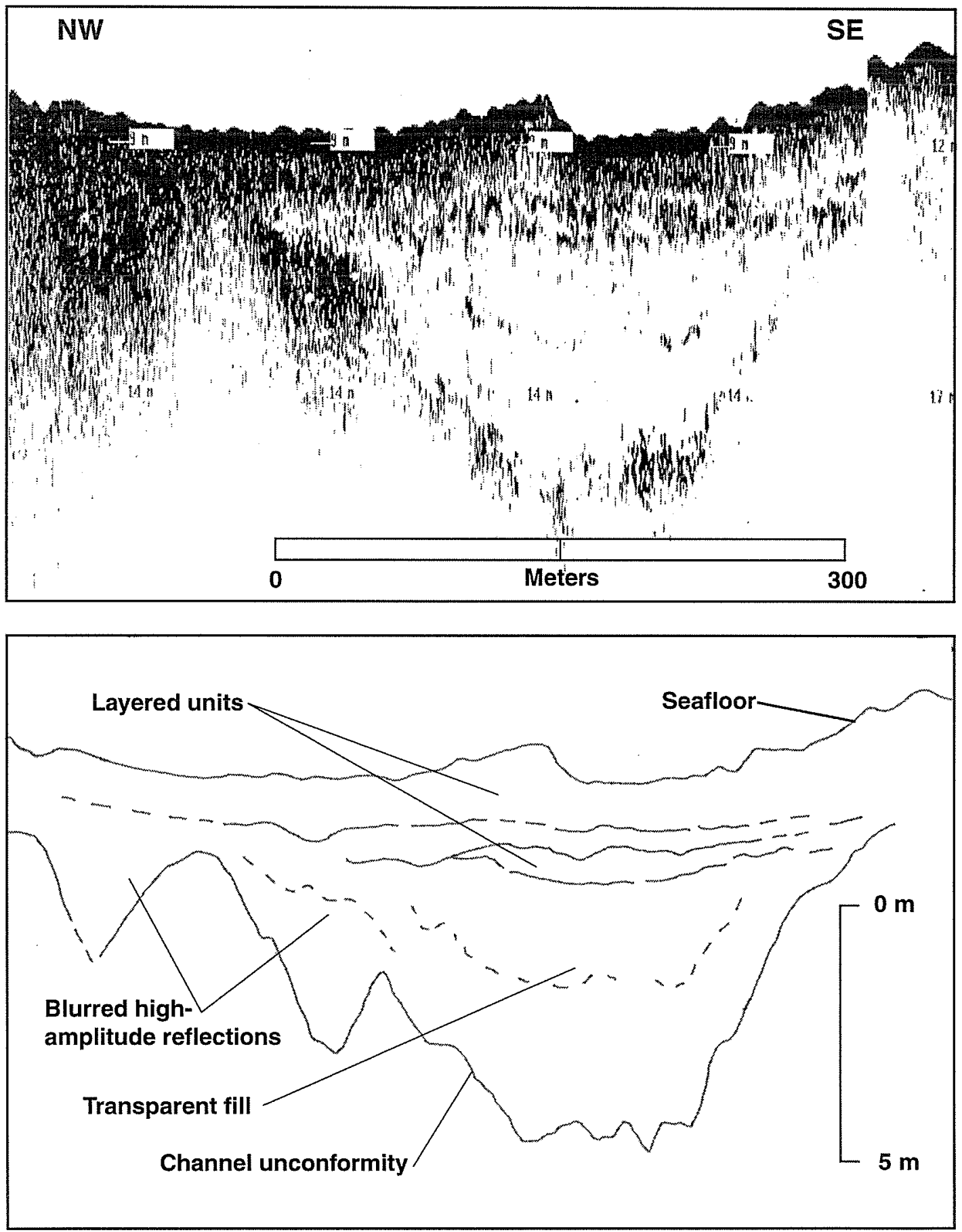

Figure 10. Interpretation of a CHIRP profile crossing the Trunk Channel shows that the channel-fill sequence consists of a transparent fill that is covered by several layered units. Blurred high-amplitude reflectors as well as discontinuous reflectors limit the image quality of the regions to either side of the large channel. (See Figure 9 for location). 


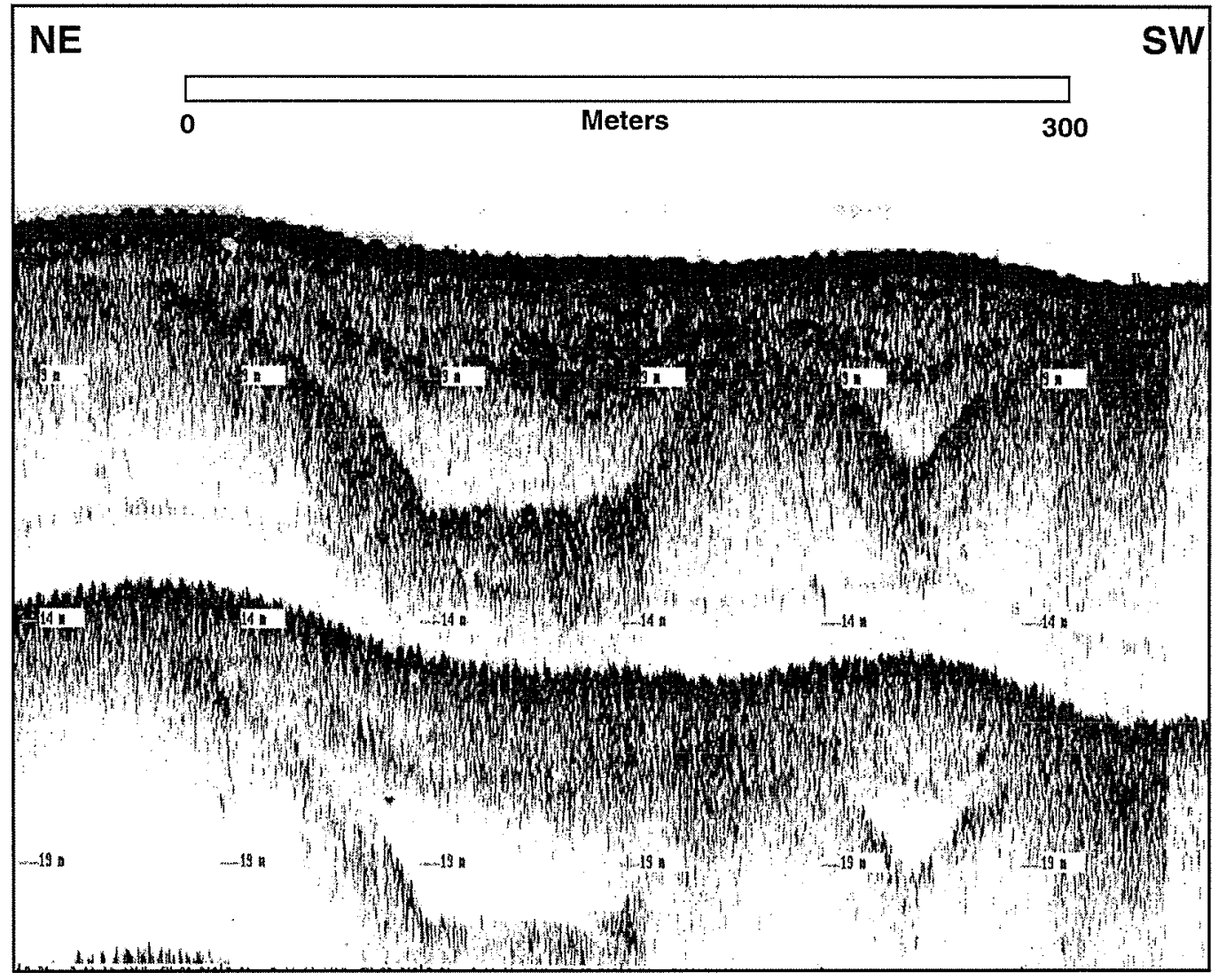

Figure 11. CHIRP sub-bottom profile from survey-line 42 crossing Channel A (See Figure 9 for location). 


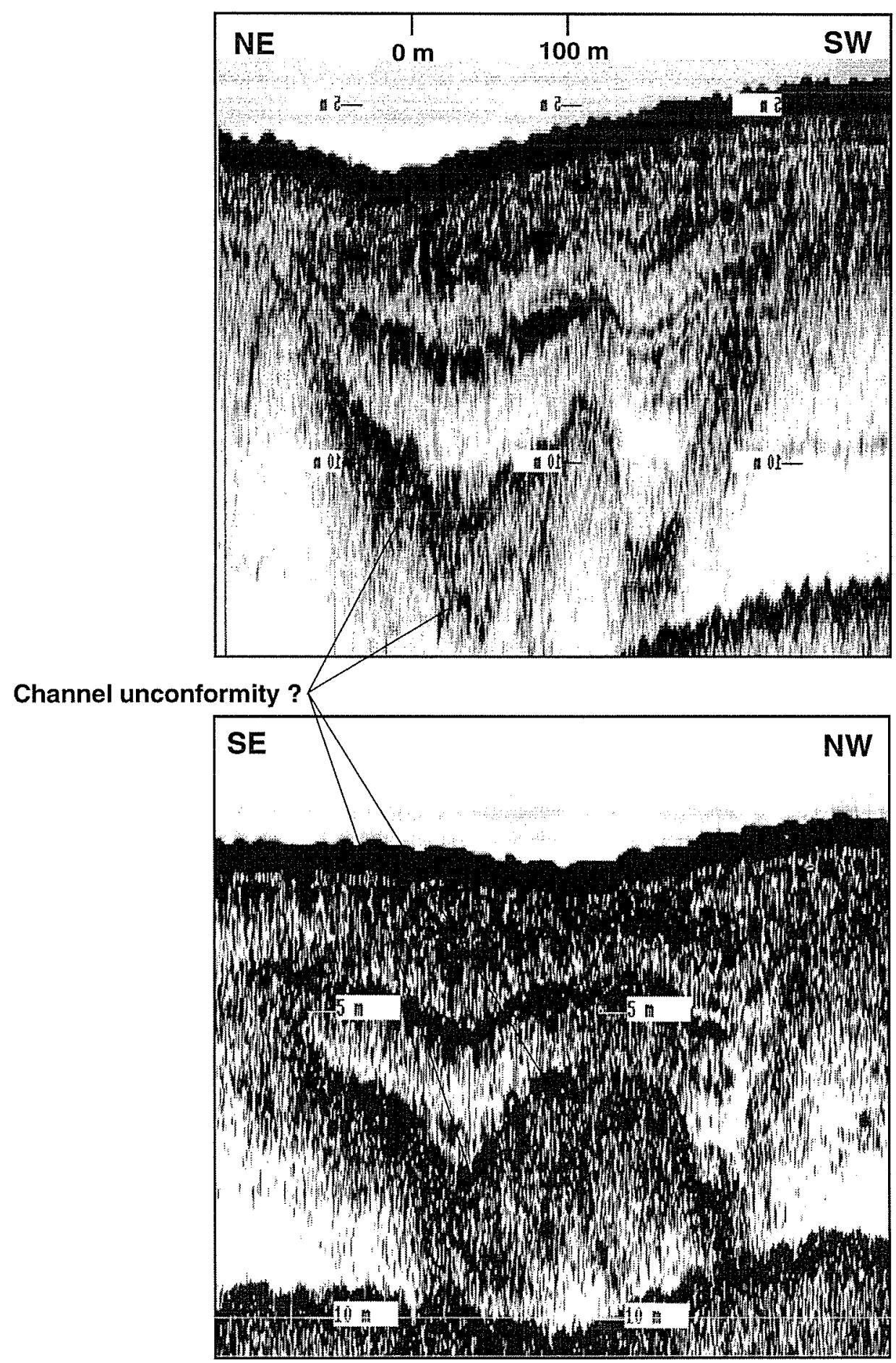

Figure 12. Two profiles that intersect over Channel A show two Vshaped lows that make up the channel. The basal channel reflector is difficult to determine. The top image (survey line 12p) suggests that a separate acosutic unit overlies the base of tha channel. This distinction is rare in the images of Channel A (See Figure 9 for location). 


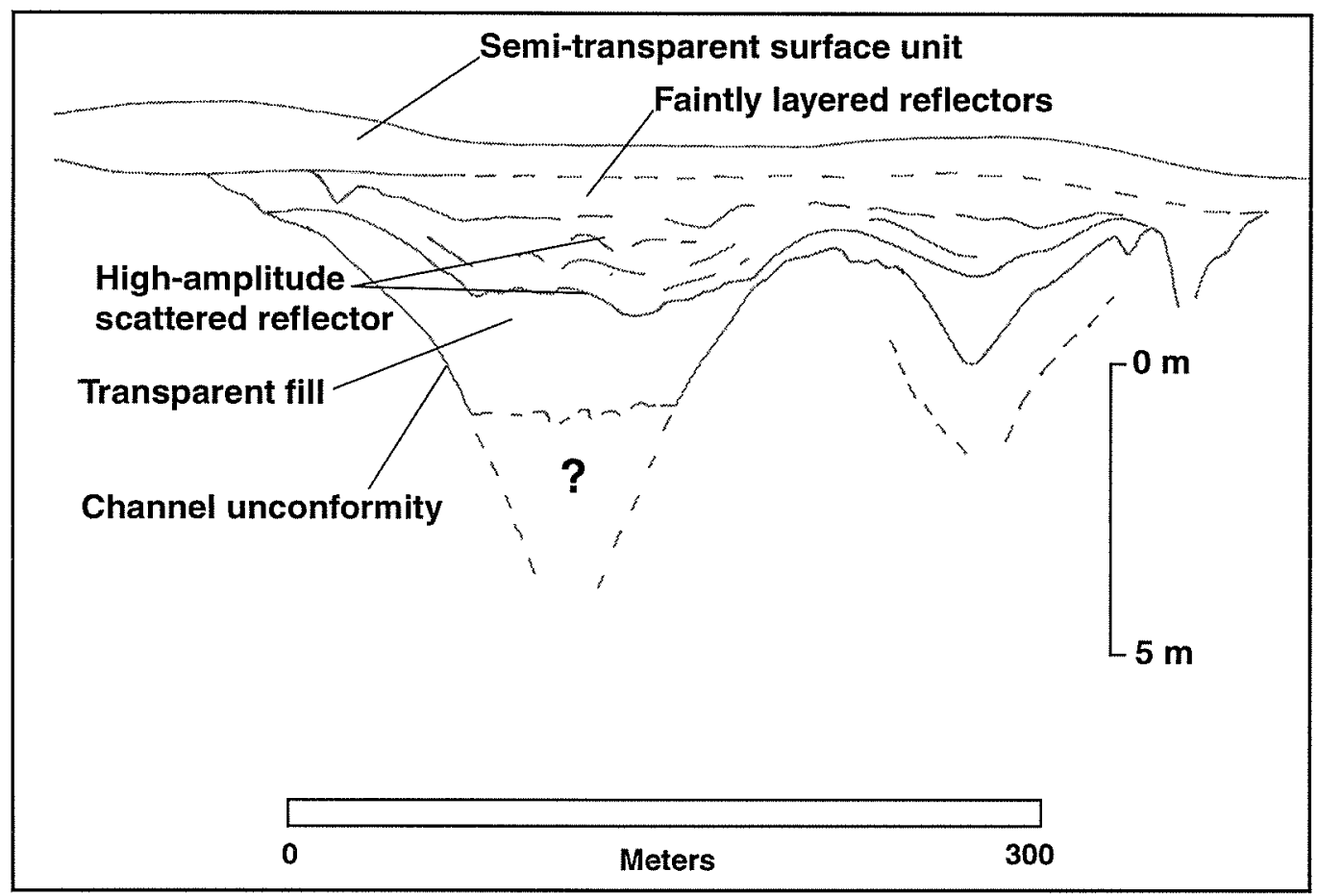

Figure 13. A CHIRP profile of Channel A from survey-line 42 (See Figure 11) indicates that the channel is filled with a transparent fill capped by scattered high-amplitude reflectors. The highamplitude region is then succeded by faintly layered relfectors. A semi-transparent unit covers this sequence. The base of the channel sequence is not well defined in CHIRP images. 


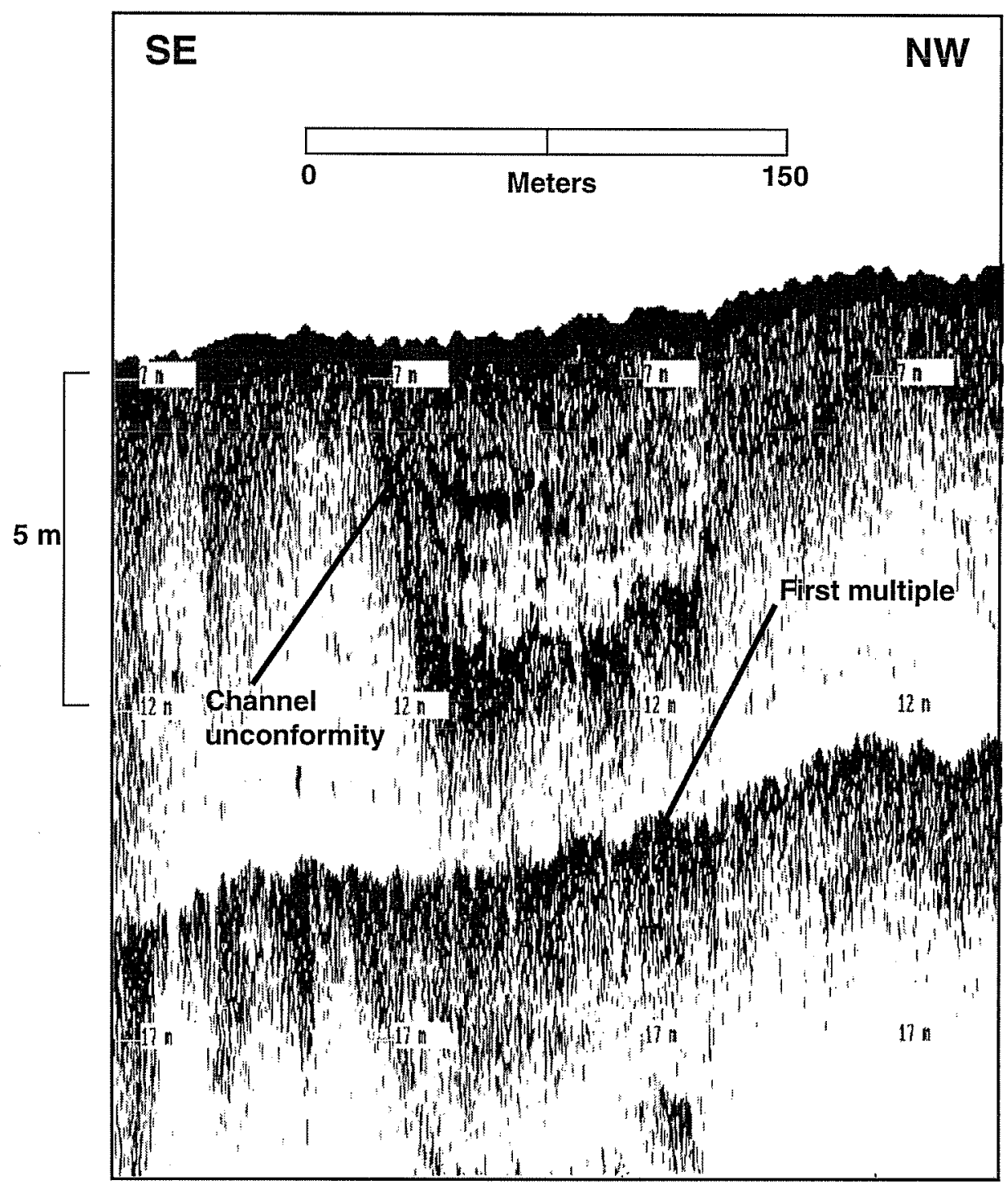

Figure 14. CHIRP profiles of Channel B show that this feature consists of one main channel that branches into several smaller channels to the north (See Figure 9). 


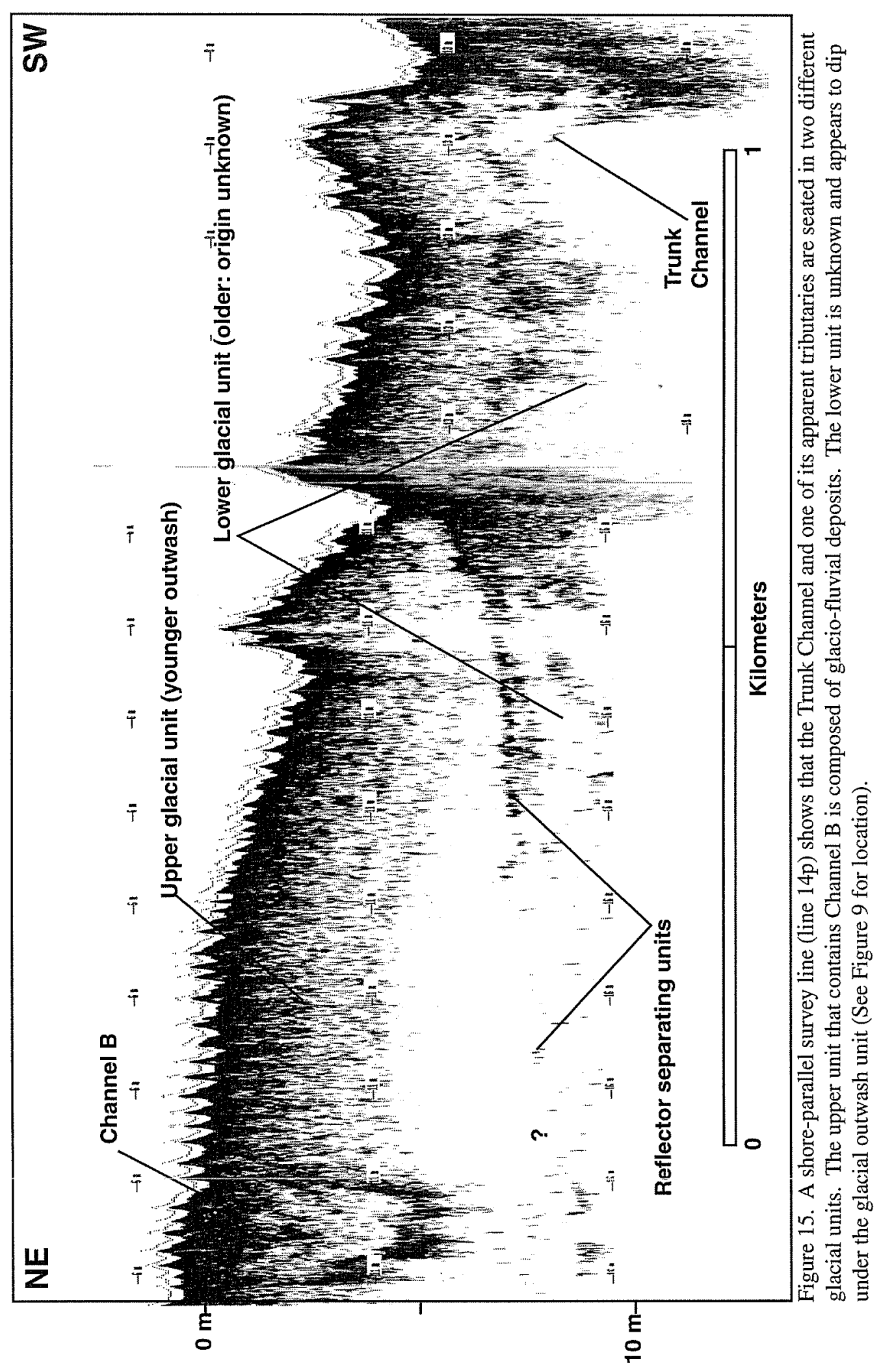




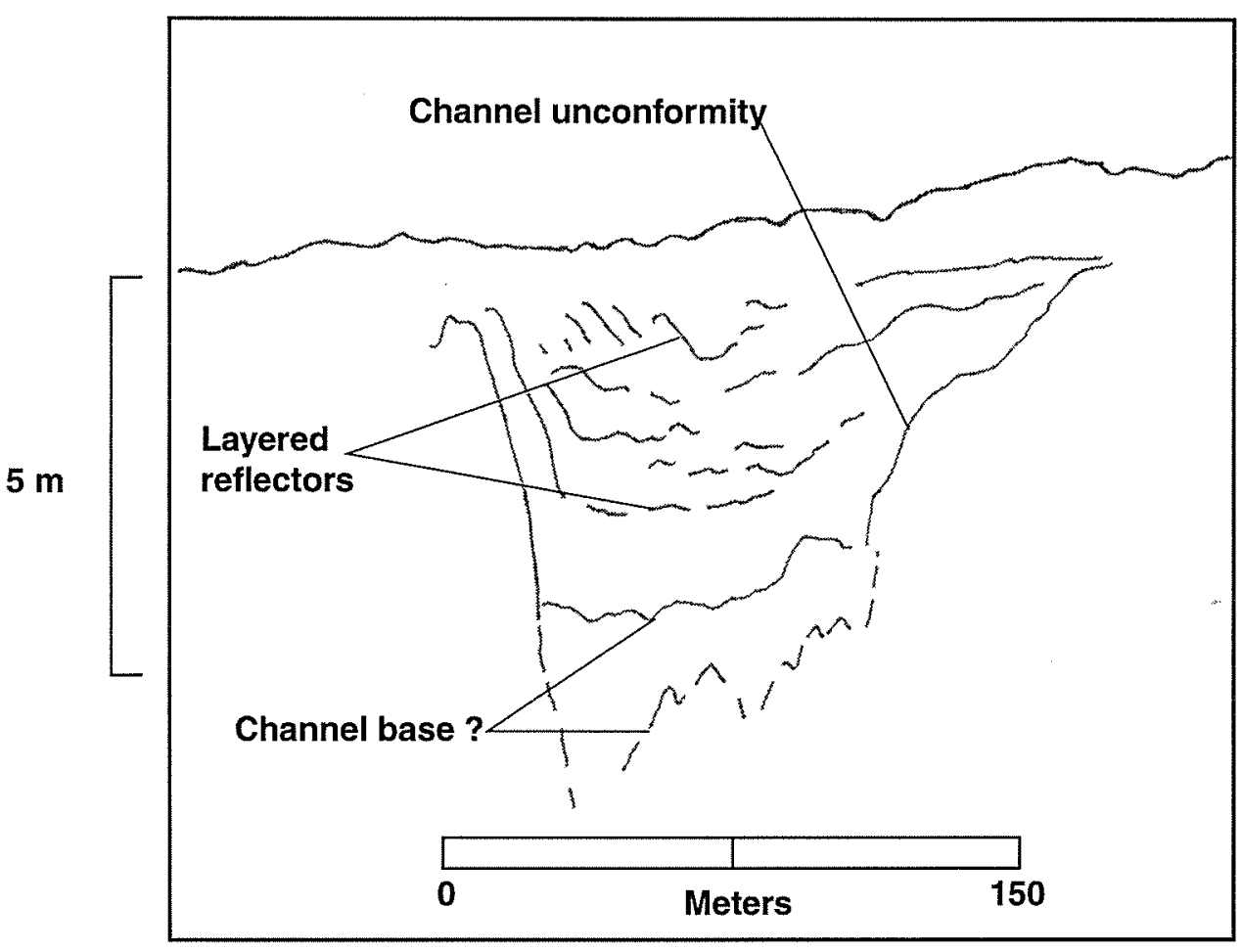

Figure 16. CHIRP profiles from Channel B show that several reflectors are present in the channel sequence. The base of the channel is difficult to determine due to the high-amplitude reflections and interference from the first multiple (See Figure 9 for location and Figure 14 for CHIRP profile). 

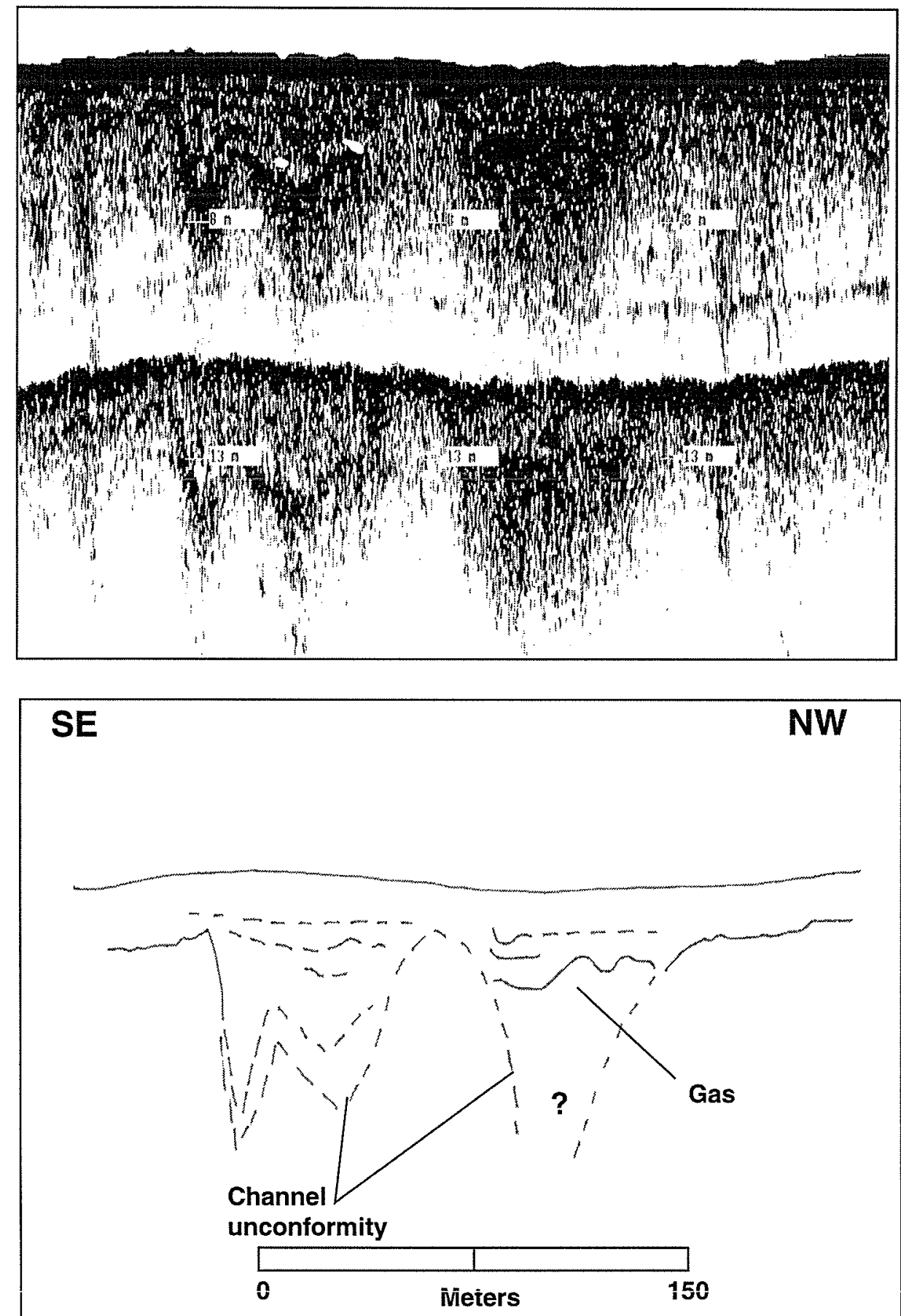

Figure 17. CHIRP image of Channel C coinciding with survey line 39 (See Figure 9 for location). The channel stratigraphy is difficult to decifer due to high amplitude reflectors caused by biogenic gas. 

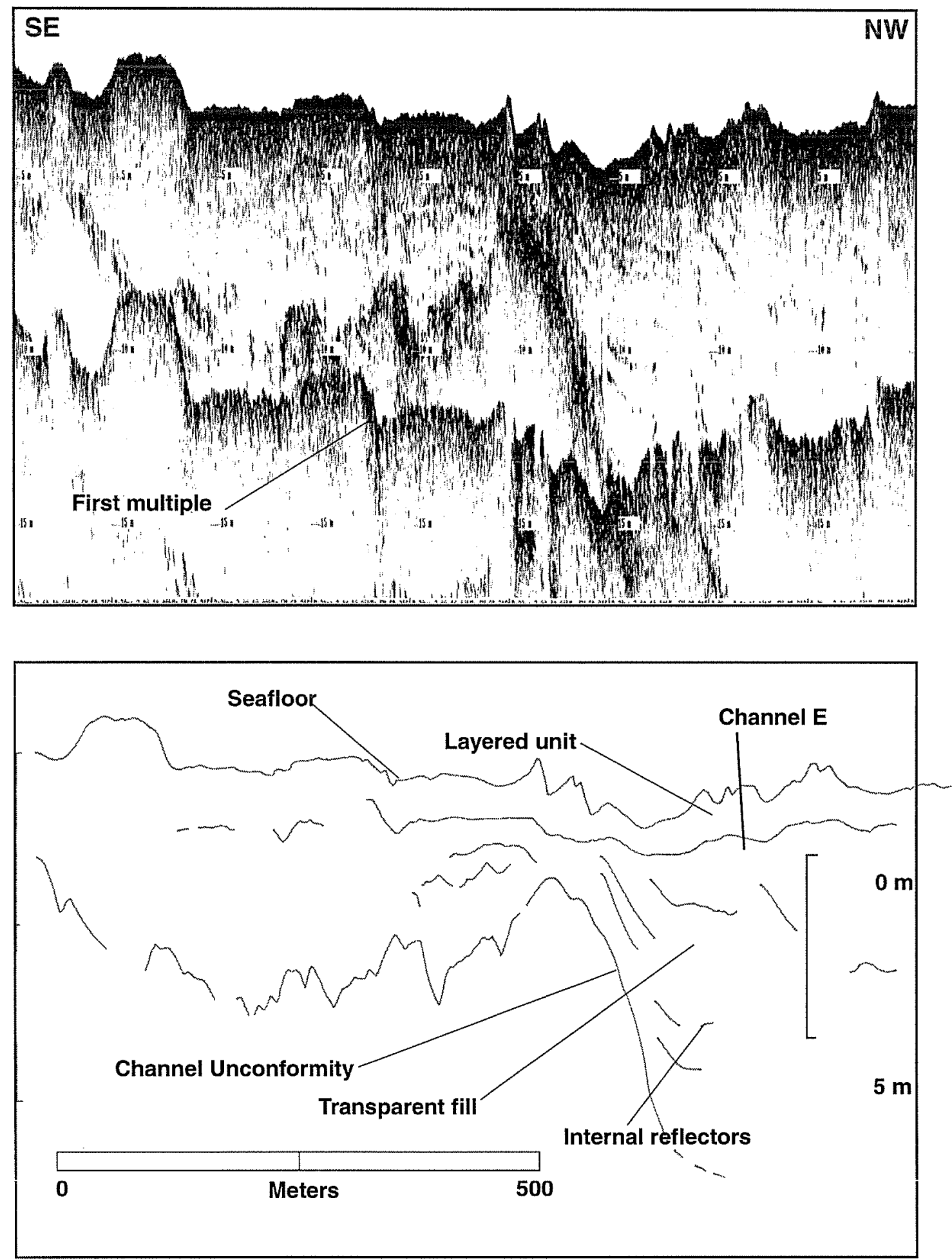

Figure 18. This CHIRP profile of Channel E indicates the sequence consists of a tranparent unit capped by a layered acosutic unit that is exposed at the seafloor. Several internal reflectors are present in the transparent unit (See Figure 9 for location). 
Figure 19. (Following page) CHIRP images of small channels imaged along survey lines 3 and 5. These channels occur on the western edge of the study site (See Figure 9). The lower portions of the channel sequence are blurred due to the presence of biogenic gas. High-amplitude reflectors in the upper portions of the channel images limit the assessment of the upper portions of the sequence as well. 

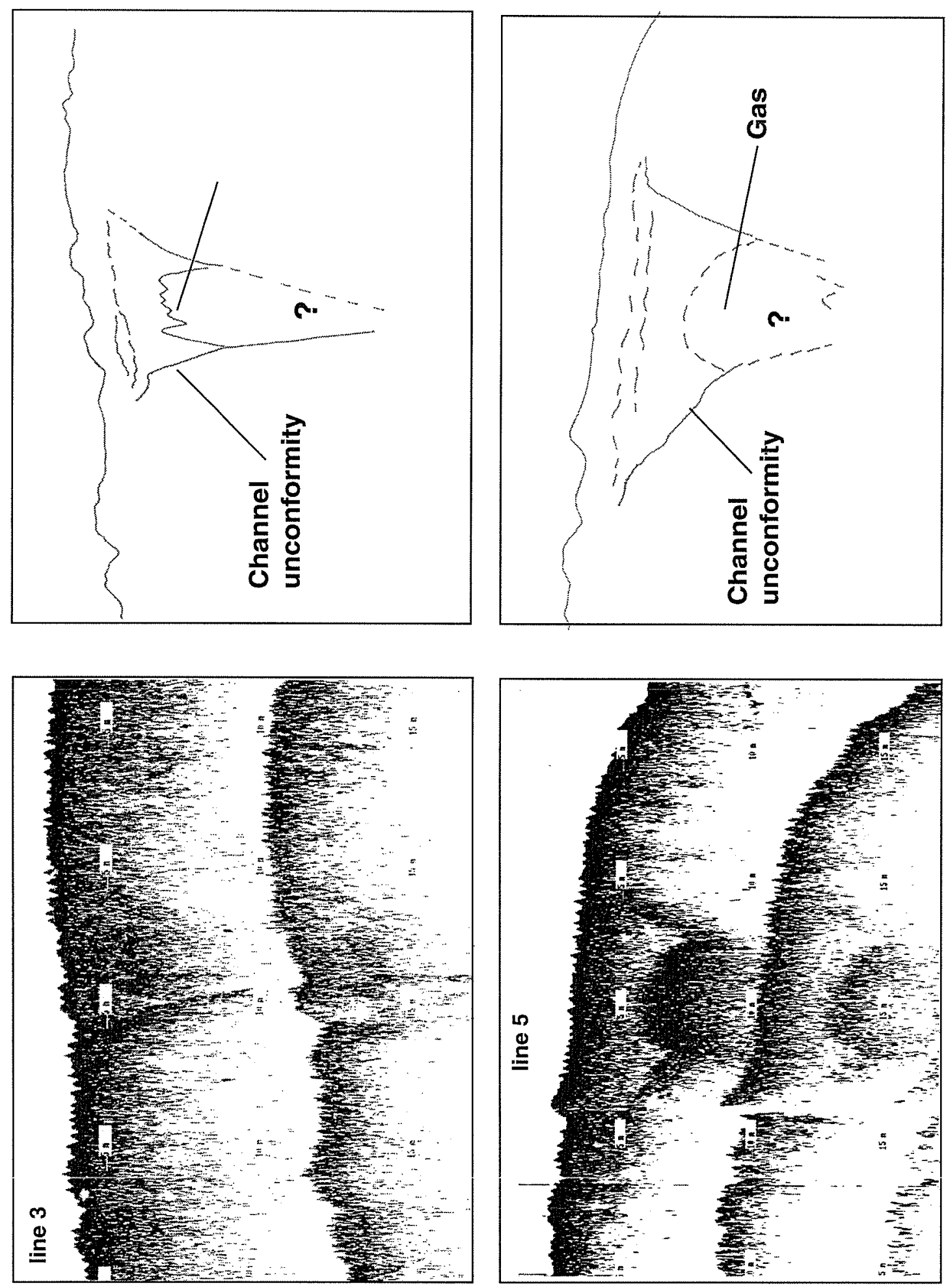


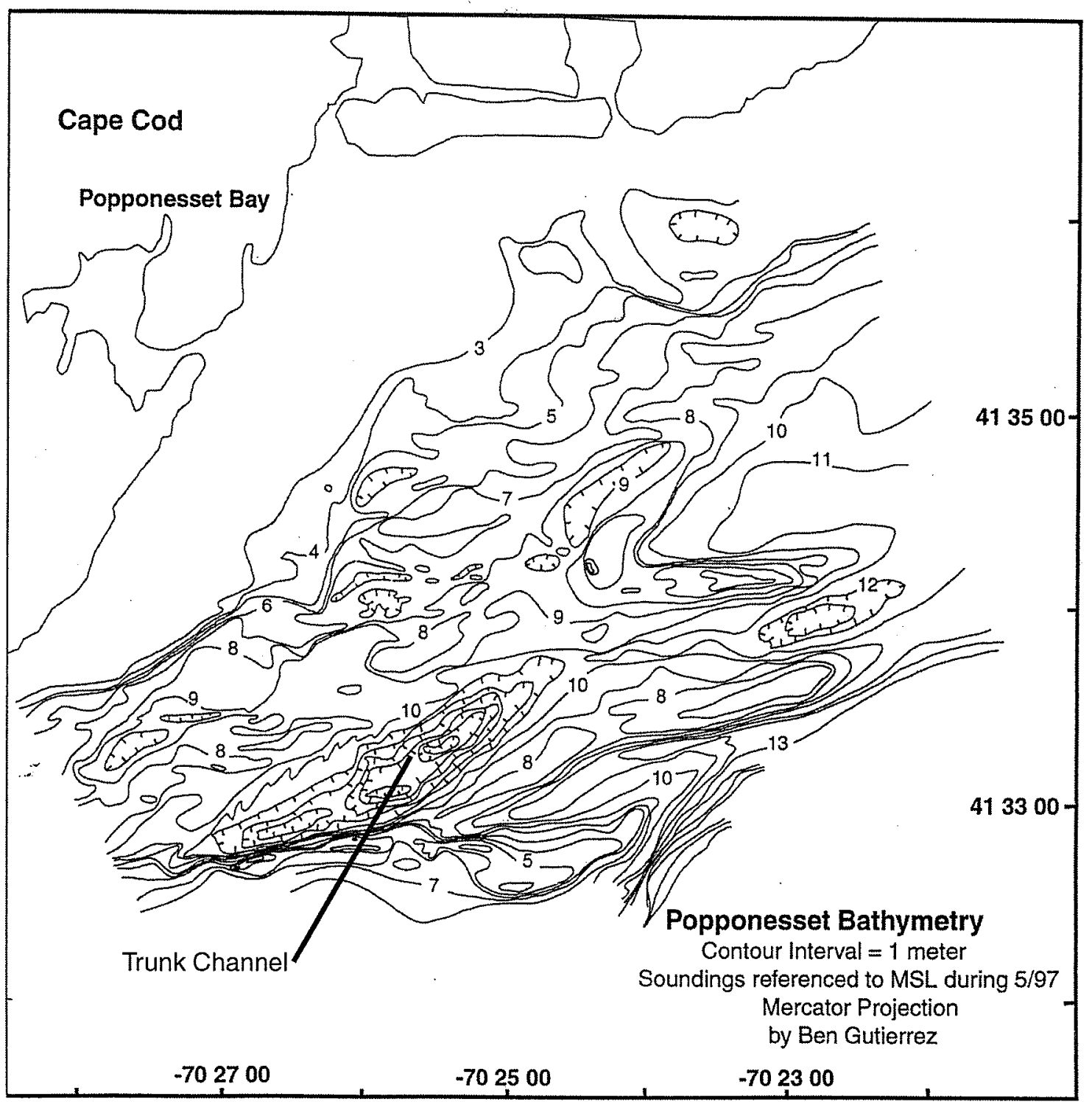

Figure 20. Bathymetry of the study area. The position of the Trunk Channel coincides with the large low that reaches 16 meters below present mean sea level. 
Figure 21. (Following page) Depth to late-Pleistocene glacial drift deposits (After O'Hara and Oldale, 1987). Dashed lines represent inferred channel paths determined from the structure of the glacial surface. Solid lines show the track lines along which seismic data for O'Hara and Oldale (1987) was collected over the site studied in this paper. The upper dashed channel system is similar to the network defined in this study. Differences arise from limited penetration with the CHIRP sonar in this study and navigational differences between the two data sets. 


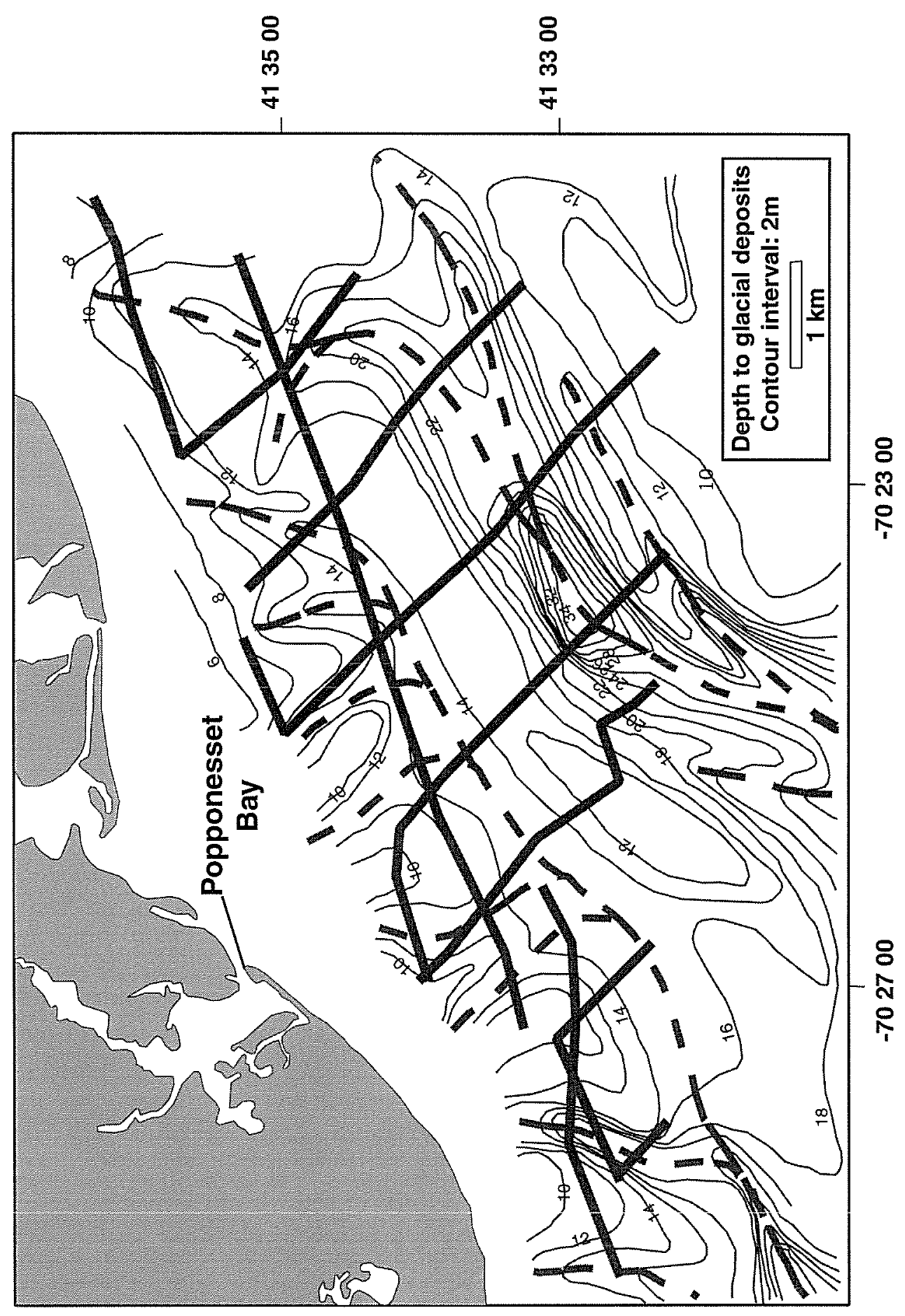


Figure 22. (Following page) Map of core locations along the channel network. 


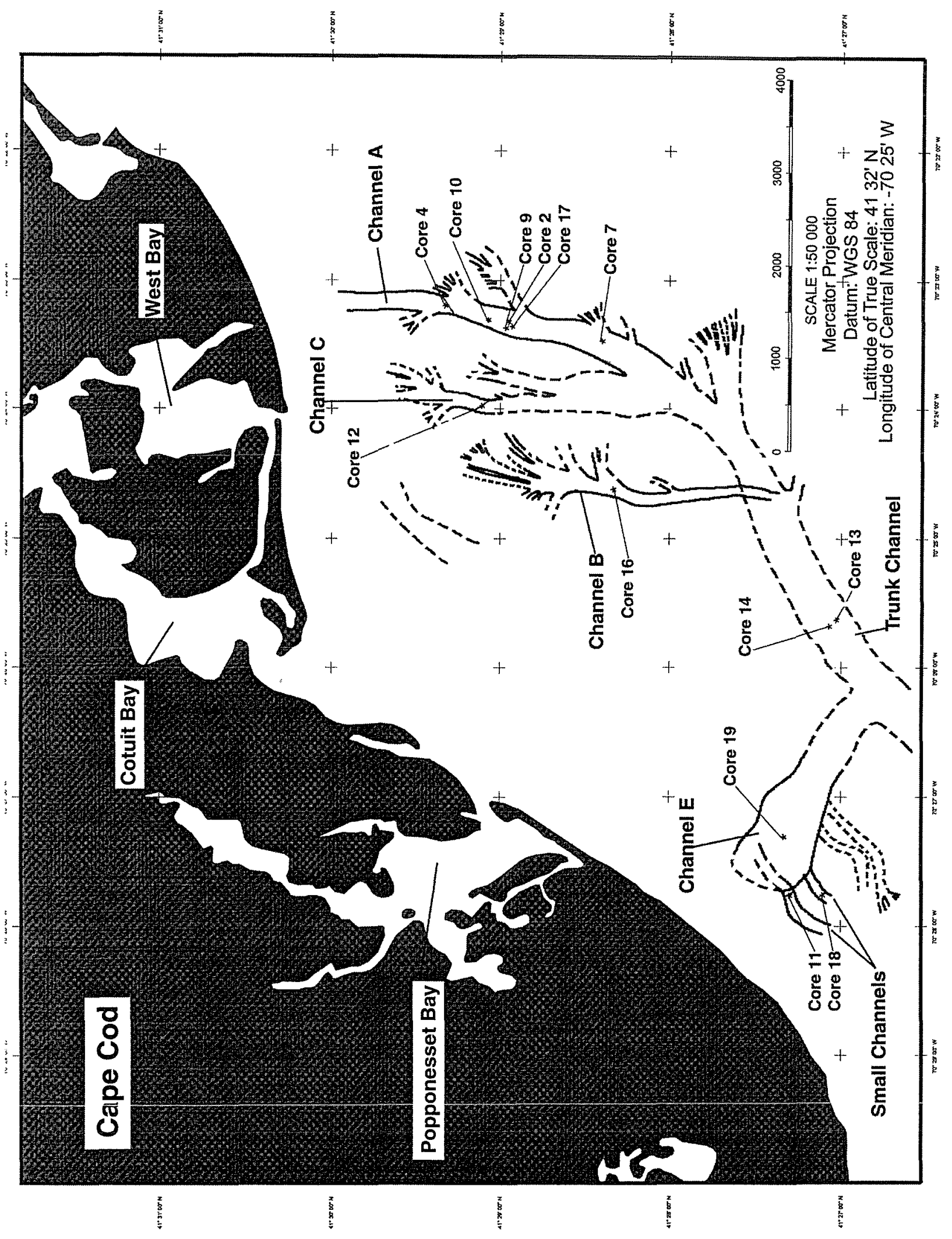




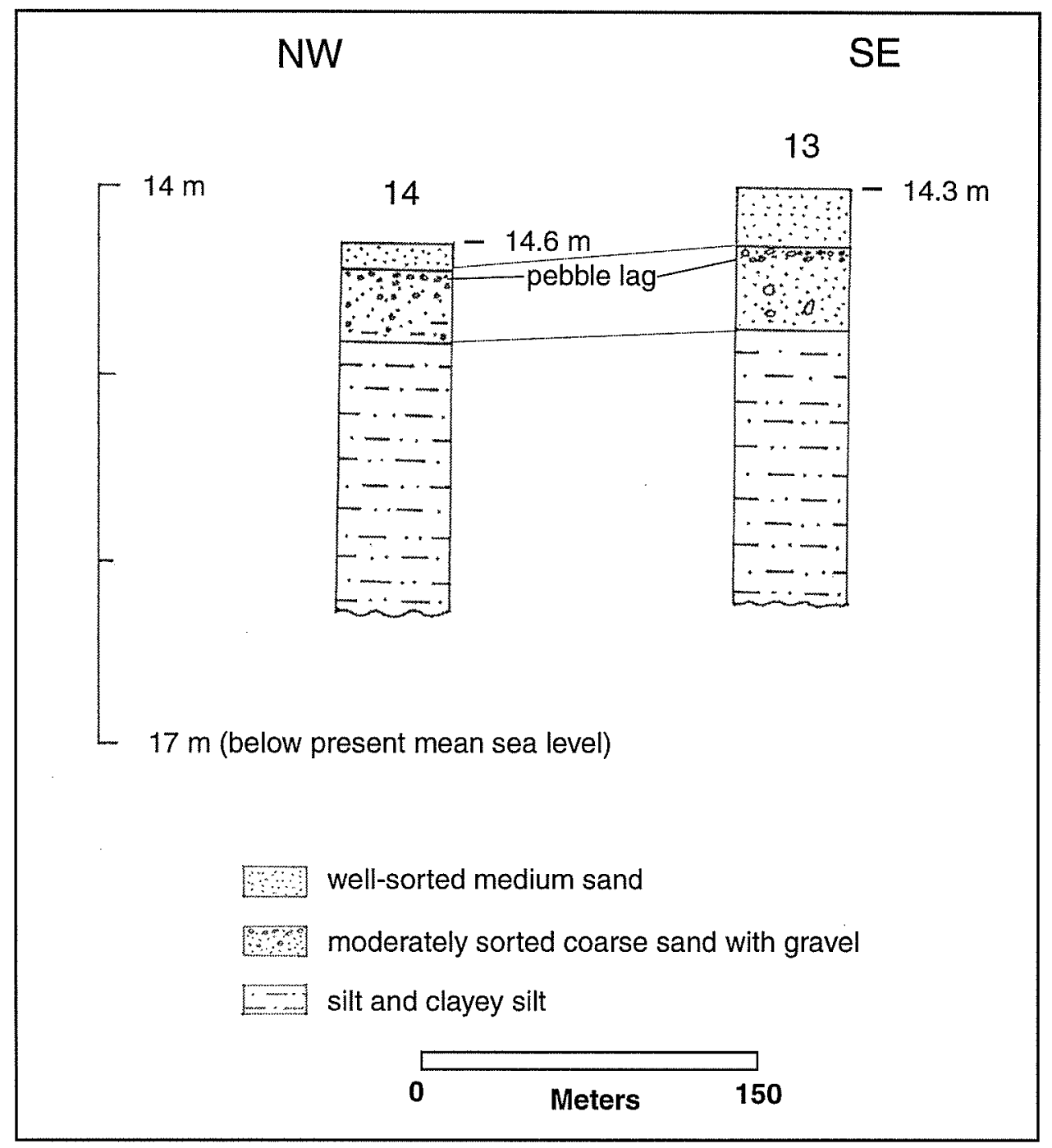

Figure 23. Schematic representation of cores 13 and 14 which were obtained from the Trunk Channel (See Figure 22 for location). Cores 13 and 14 penetrated 2.26 and 1.99 meters below the seafloor. The coarser accumulation of pebble and gravel sized clasts at the top of the lower sand unit indicates the presence of a lag at the top of this unit. Water depths of each core site are to the upper right of the cores. 


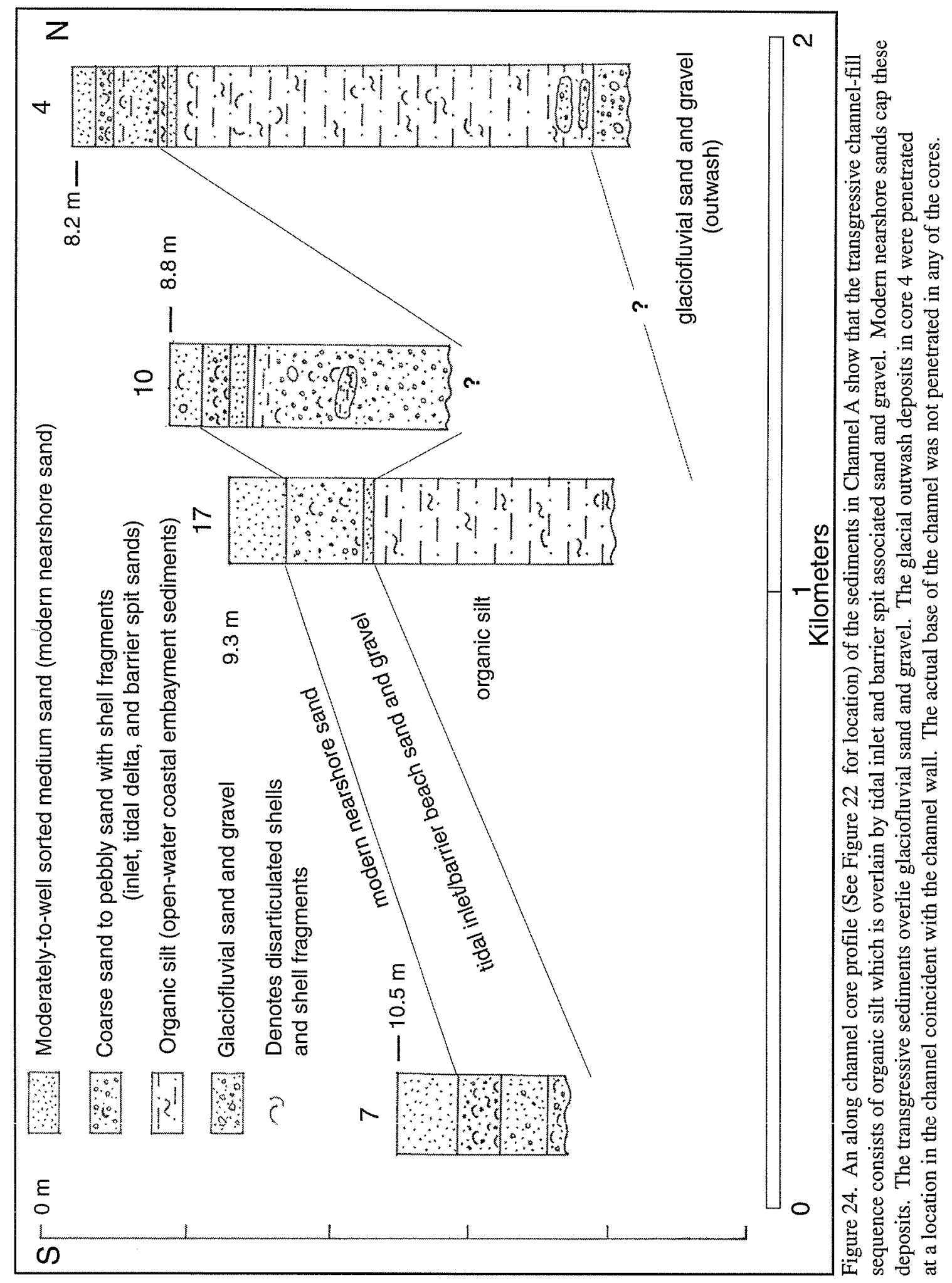




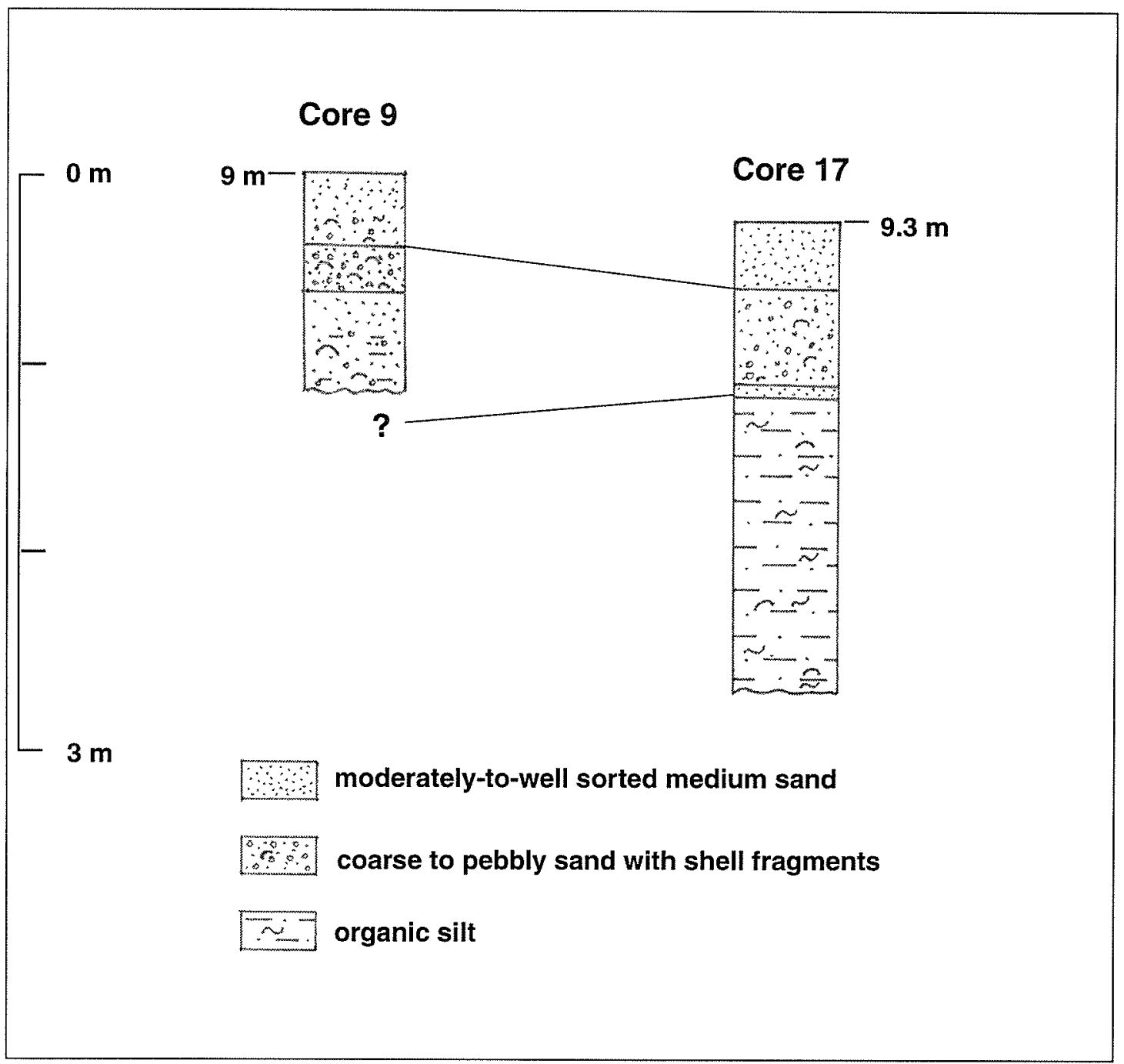

Figure 25. Two cores taken from sites across Channel A. These cores coincide with CHIRP images on survey-line 42 (See Figure 22). Cores show that the thickness of sand units associated with back-barrier and tidal inlet environments vary in thickness across the channel. This variation in thickness is related to the lateral migration of inlets and shoreface environements around tidal inlets and barrier spits. 


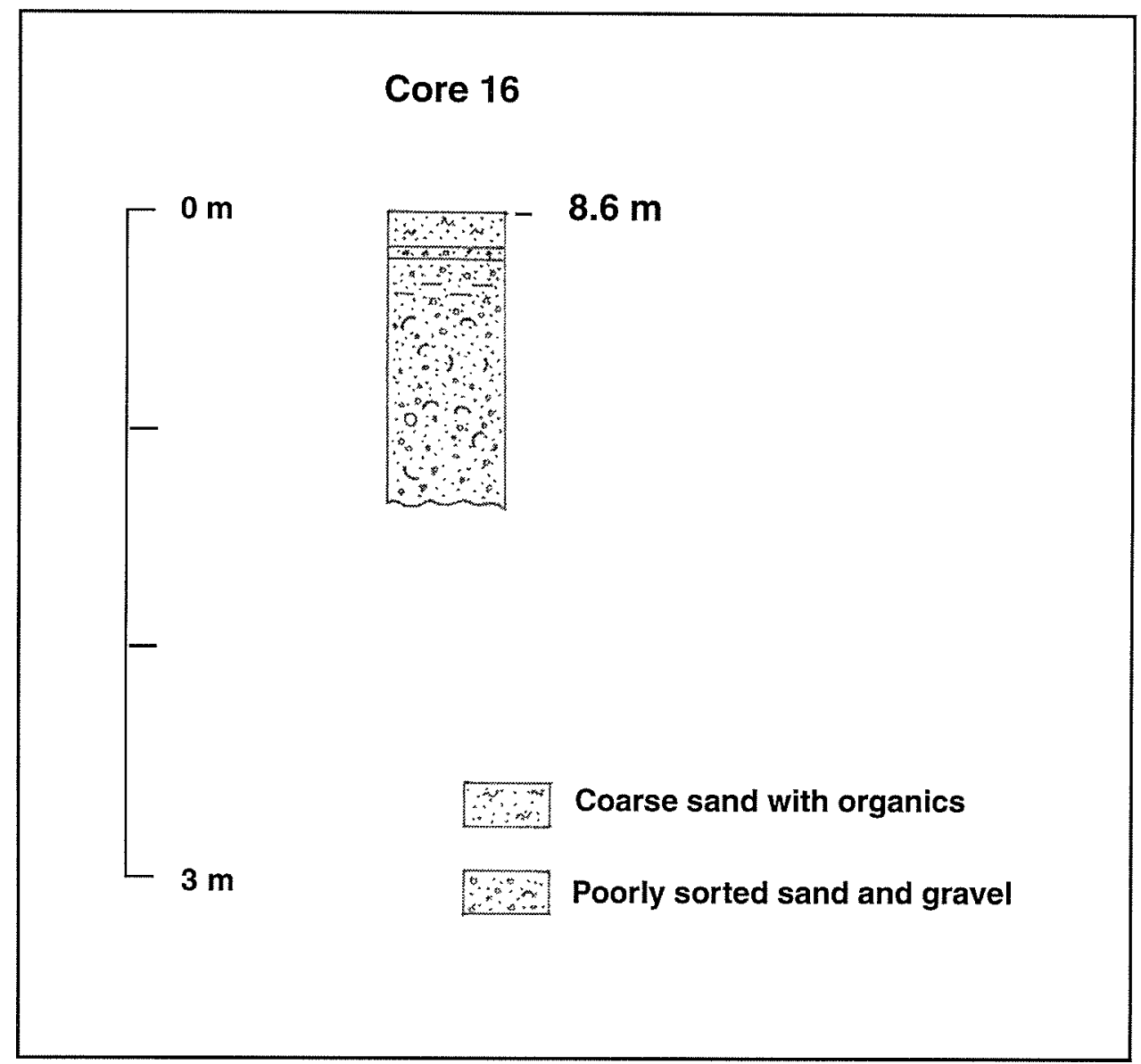

Figure 26. Core 16 penetrated the top 1.4 meters of the channel-fill sequence in Channel B. These sediments consist of poorly sorted sand and gravel. 


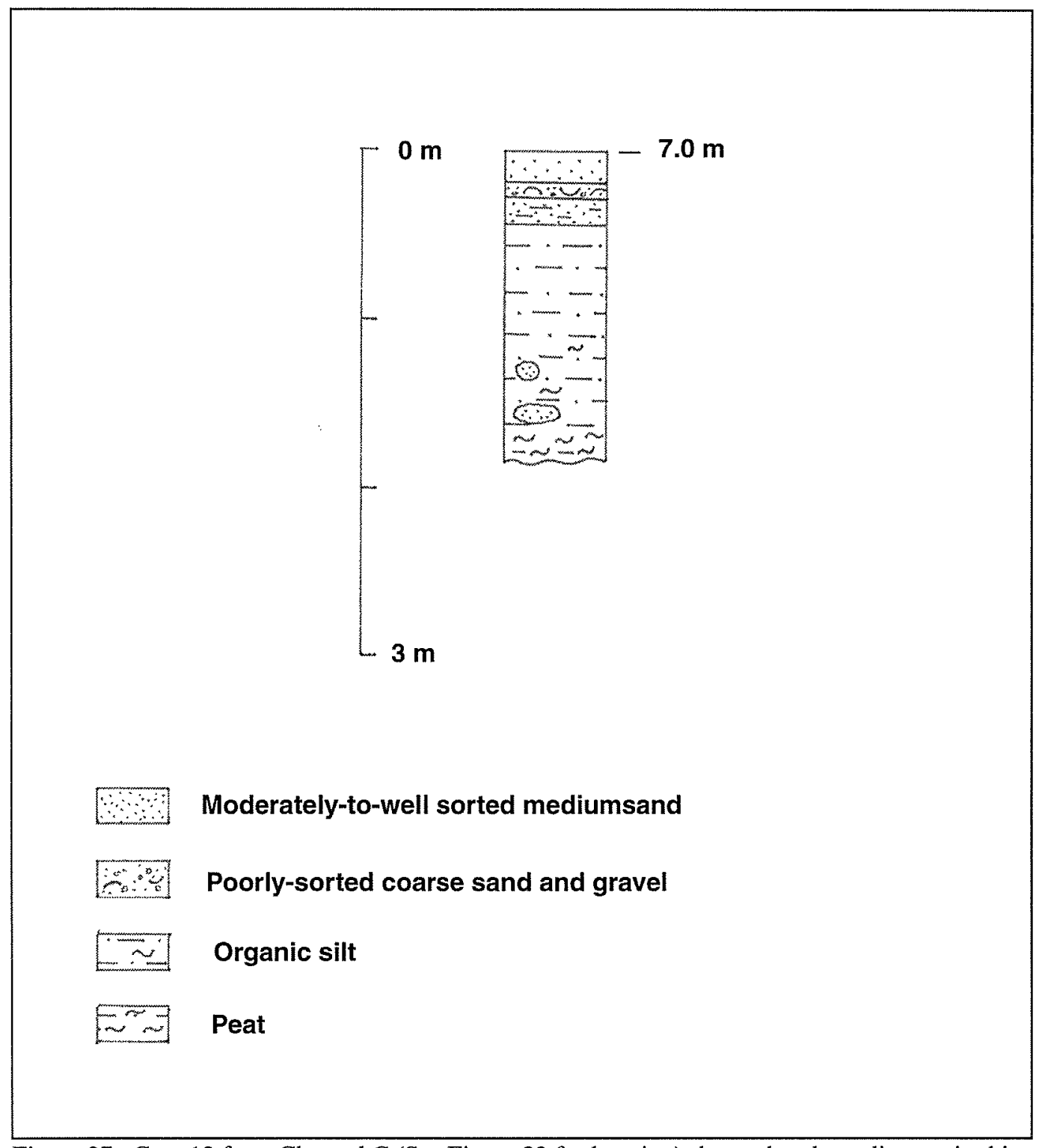

Figure 27. Core 12 from Channel C (See Figure 22 for location) shows that the sediments in this channel consist of peat and organic silt that are capped two sand units comprised of a poorly sorted coarse sand with shells and gravel and a moderately-to-well sorted medium sand. 


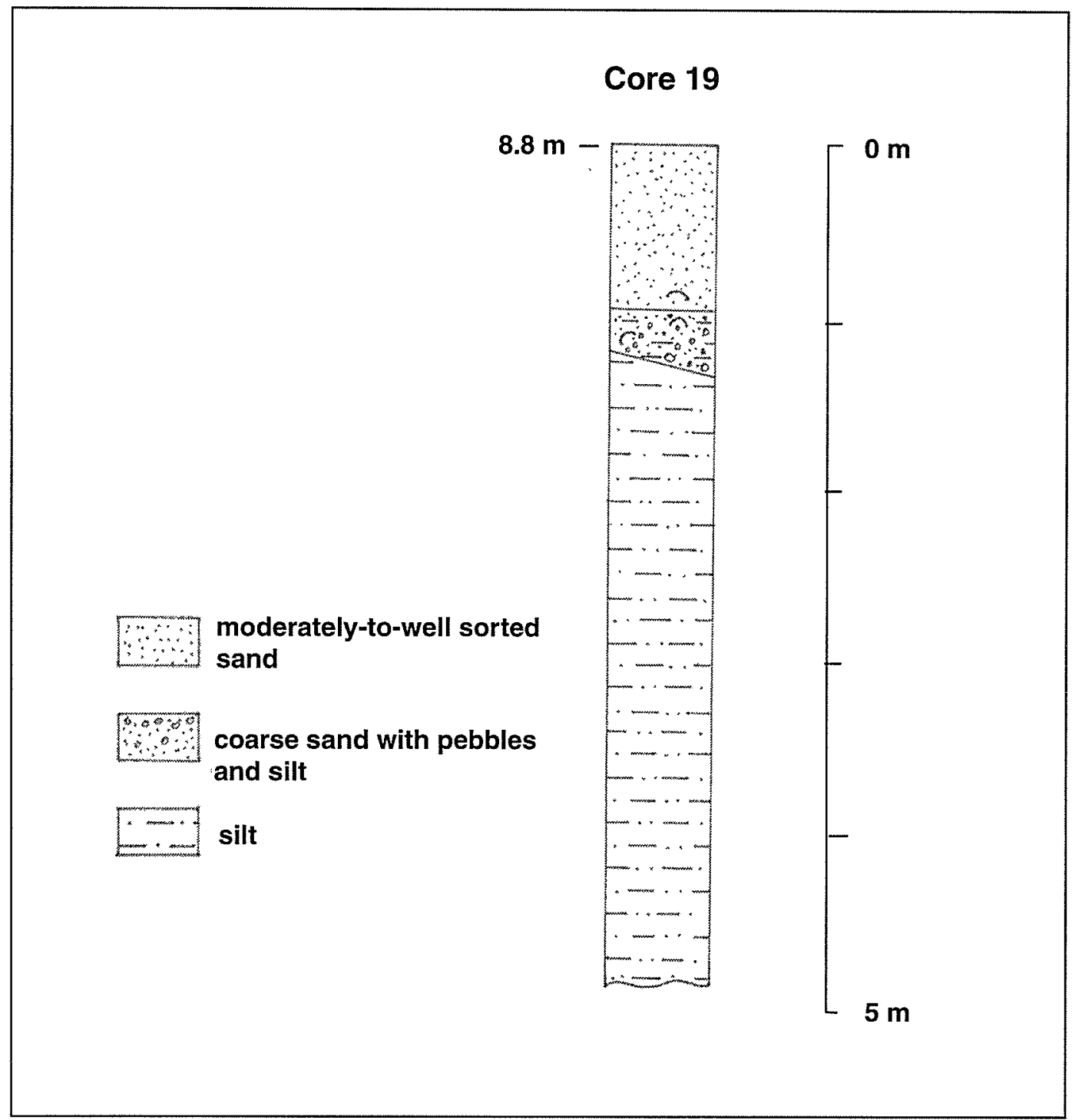

Figure 28. A core from Channel E (See Figure 22 for location) shows that the sequence in this channel consists of silt which is covered with two sand units. The lower sand unit is composed of coarse sand with shell fragments and pebbles. Silt and finer sand are abundant in pore spaces. The uppersand is composed of a moderatly-to-well sorted sand that is exposed at the sea floor. The depth ofwater is indicated to the upper left of the core. 


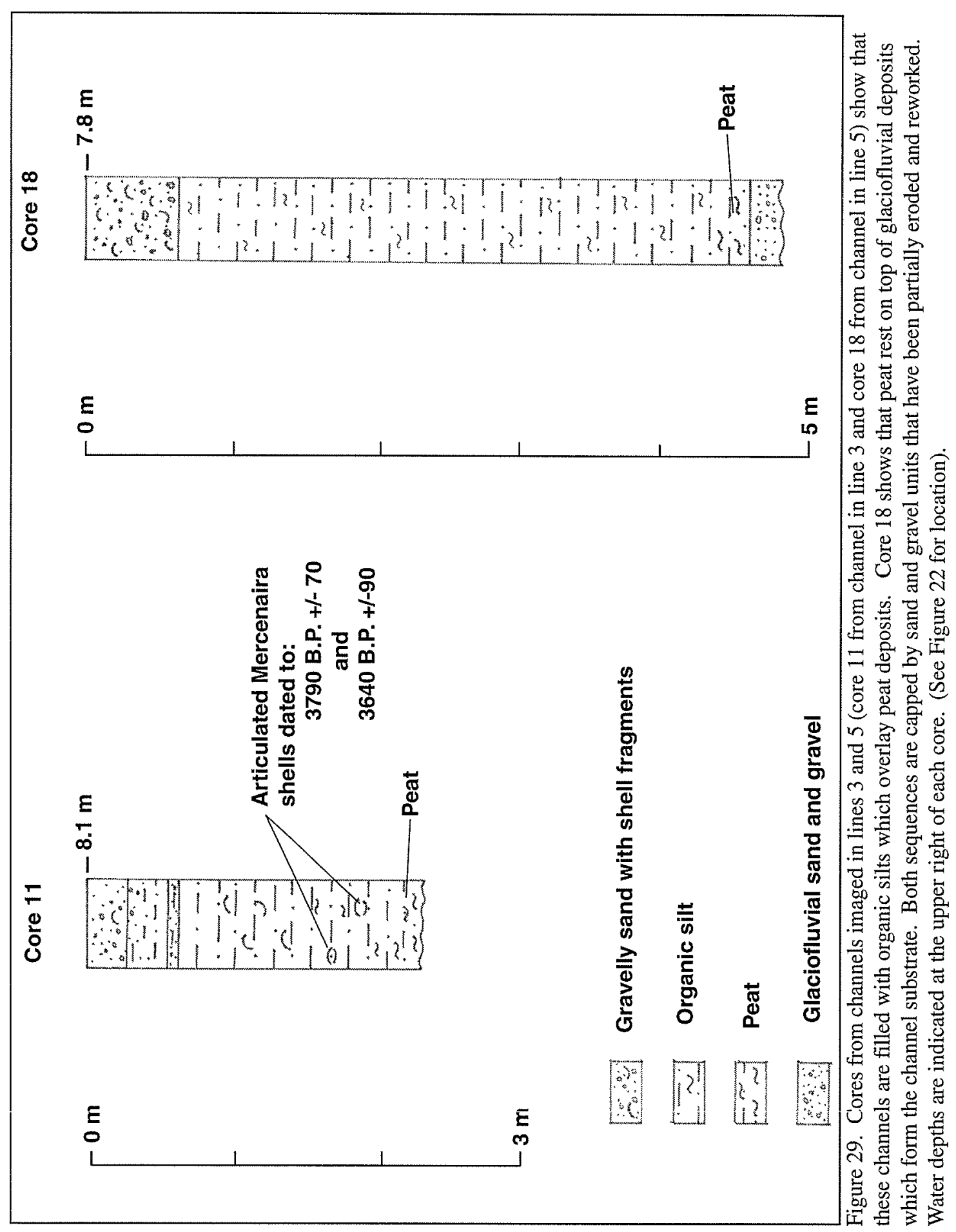




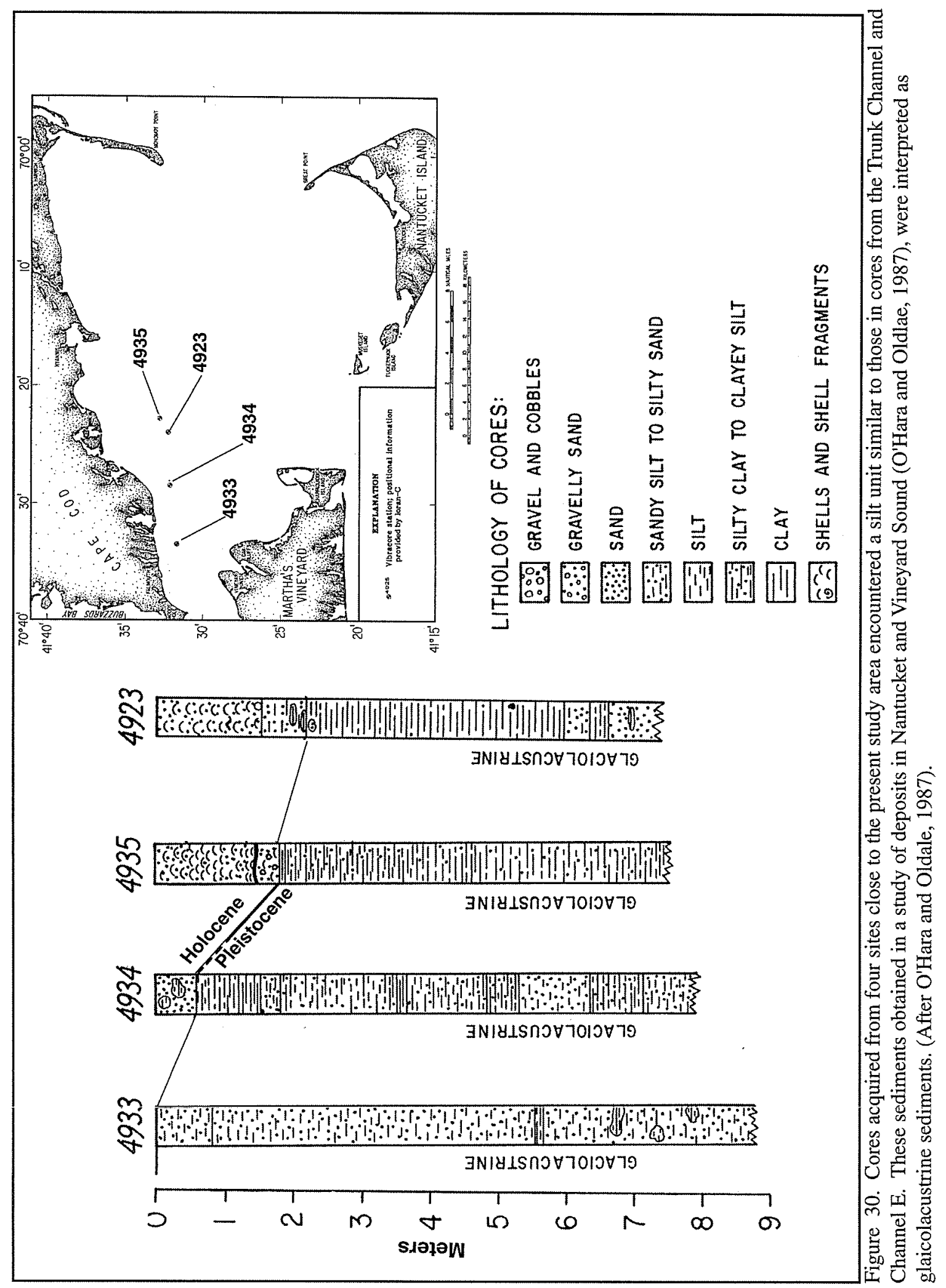




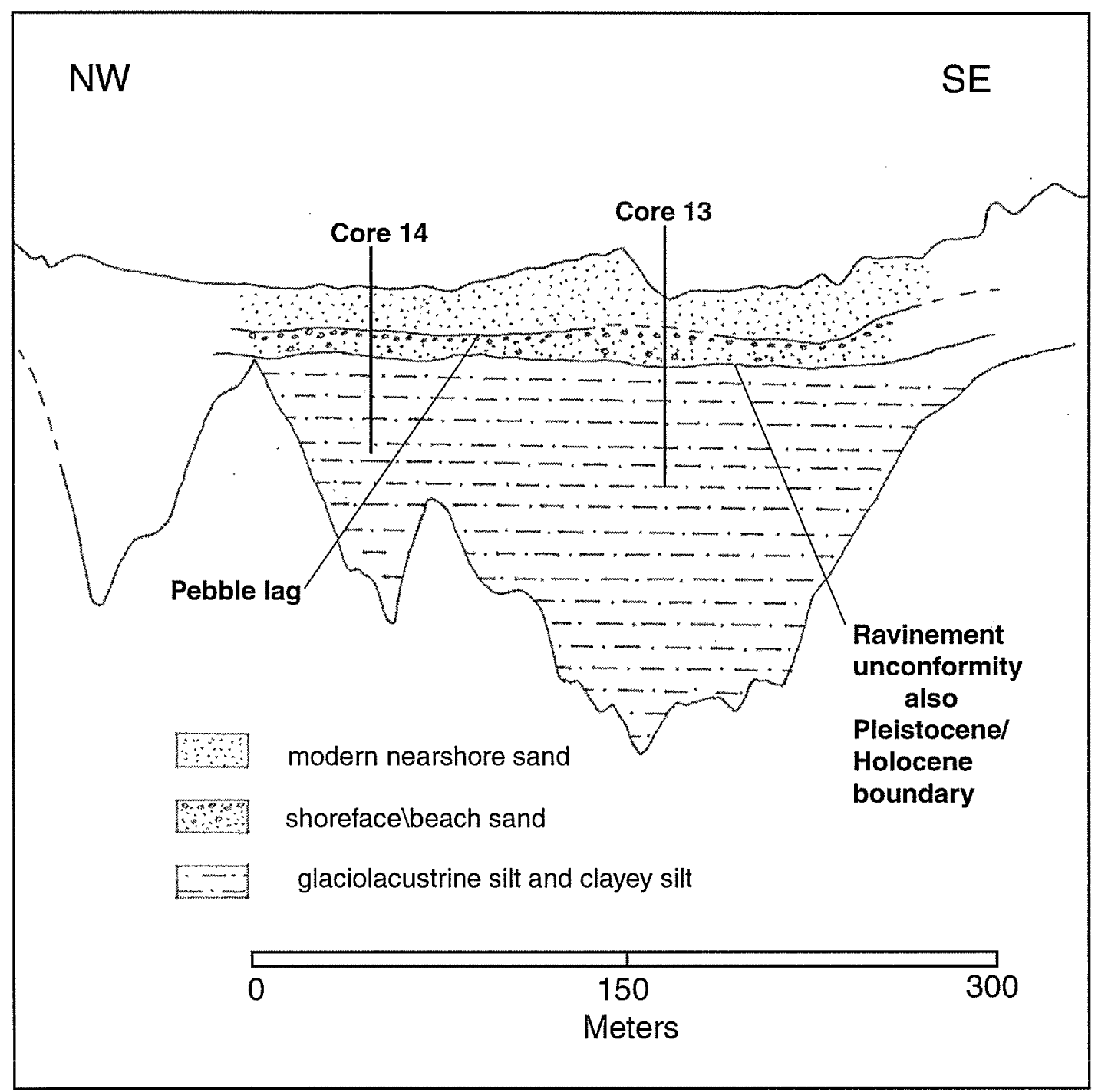

Figure 31 . Based on the two cores acquired at this site, this figure shows the sedimentary sequence that fills the Trunk Channel. The sequence consists mainly of silt that is capped by shoreface sands. Modern shelf sands in-turn cover the shoreface sand unit. 


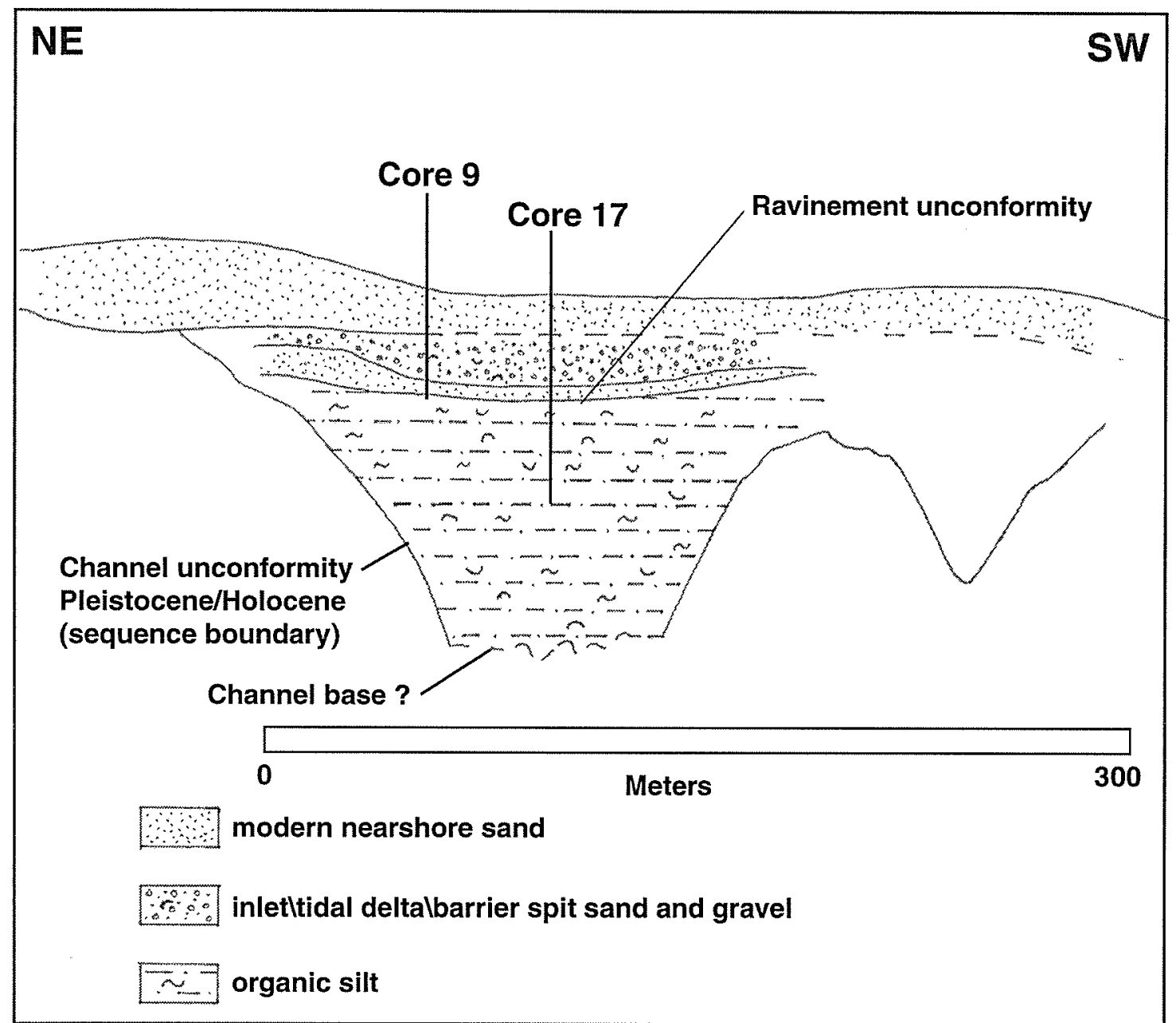

Figure 32. Cores and CHIRP images from Channel A indicate that this channel contains a transgressivefill sequence recording the evolution of a coastal emabyment. The basal channel unconformity is overlain by organic silt which relfects deposition in a protected coastal embayment. These silts are capped by inlet and barrier spits sand which reflect the shoreward migration of the shoreline with relative sea-level rise. Modern nearshore sand covers the channel-fill sequence. 


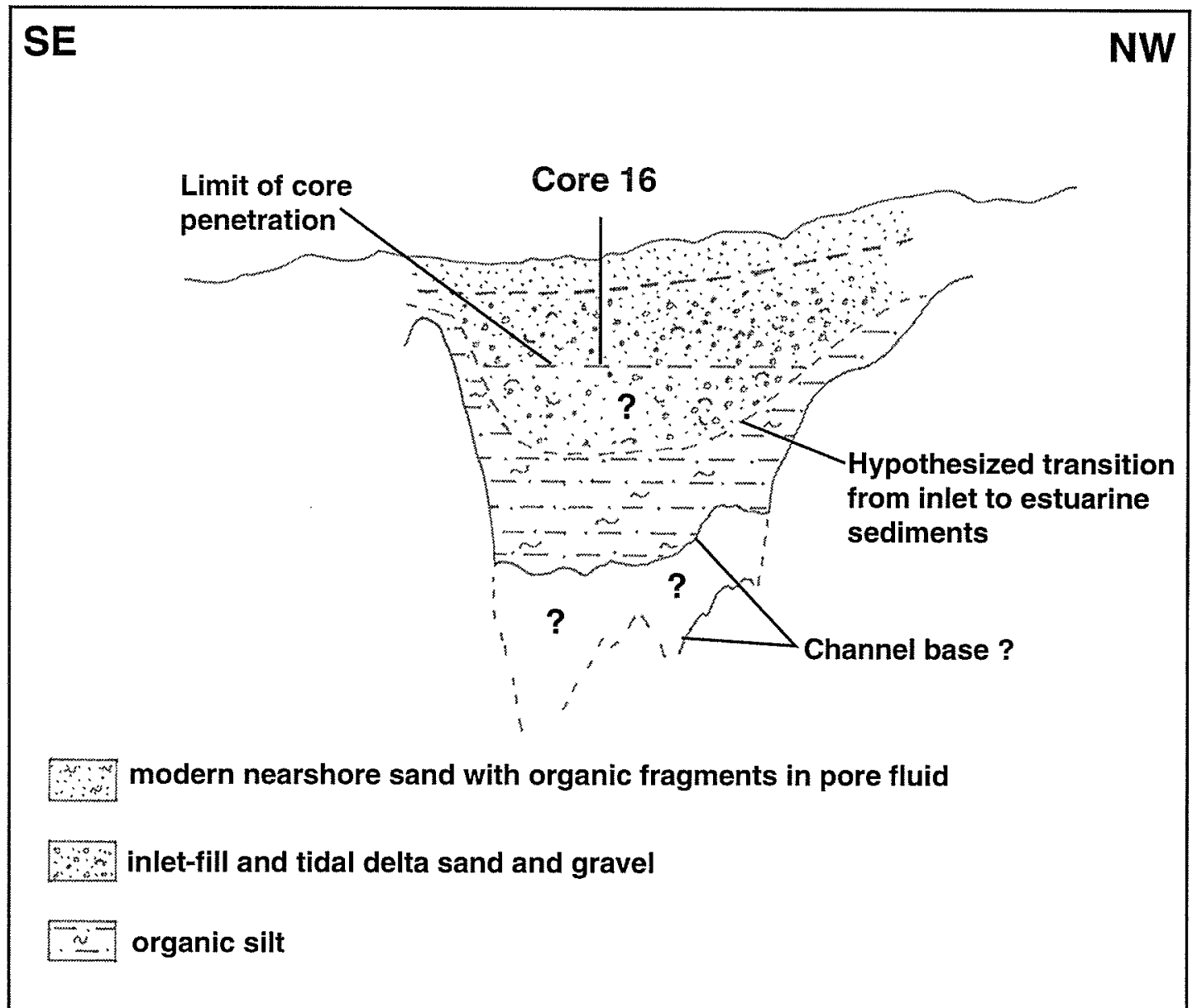

Figure 33. Based on limited information from core 11 and previous interpretations of the channel-fill sequences in Channel A, we propose the above interpretaion of the channel-fill sequence in Channel $\mathrm{B}$. 


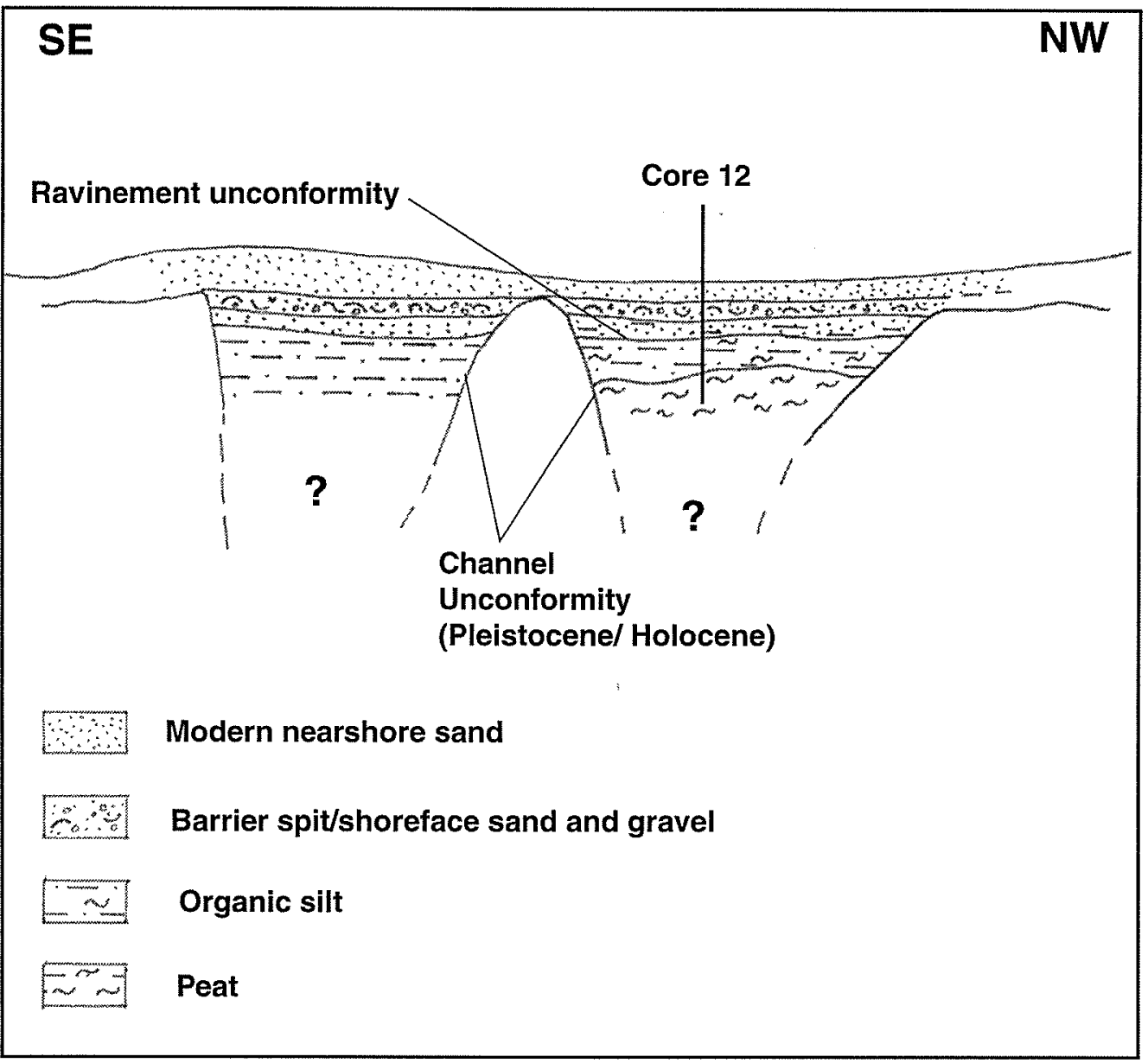

Figure 34. Integrating the core stratigraphy with the seismic stratigraphy shows that the upper portions of the channels imaged across survey line 39 are filled with a transgressive channelfill sequence similar to those defined in Channel A. 


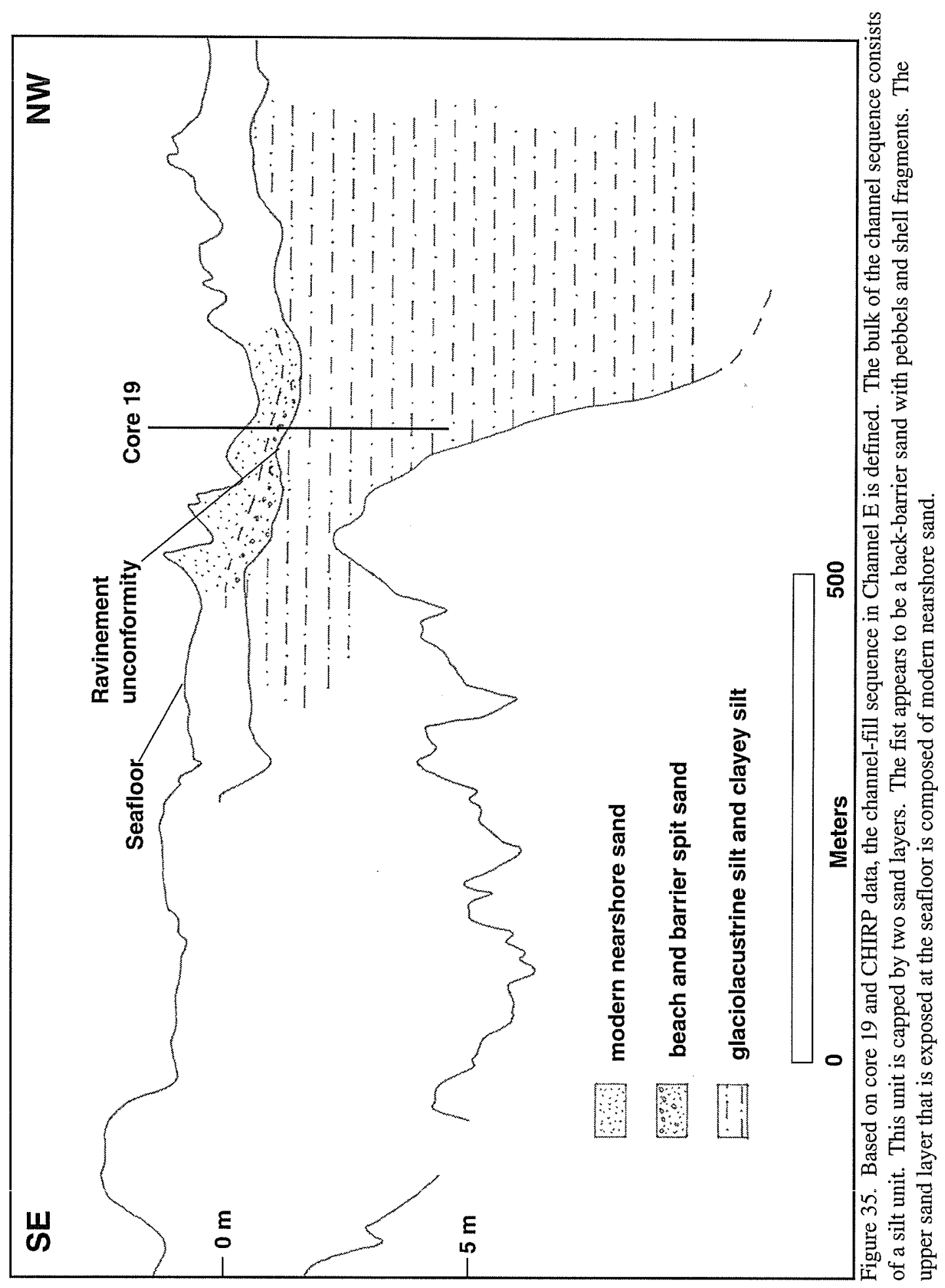




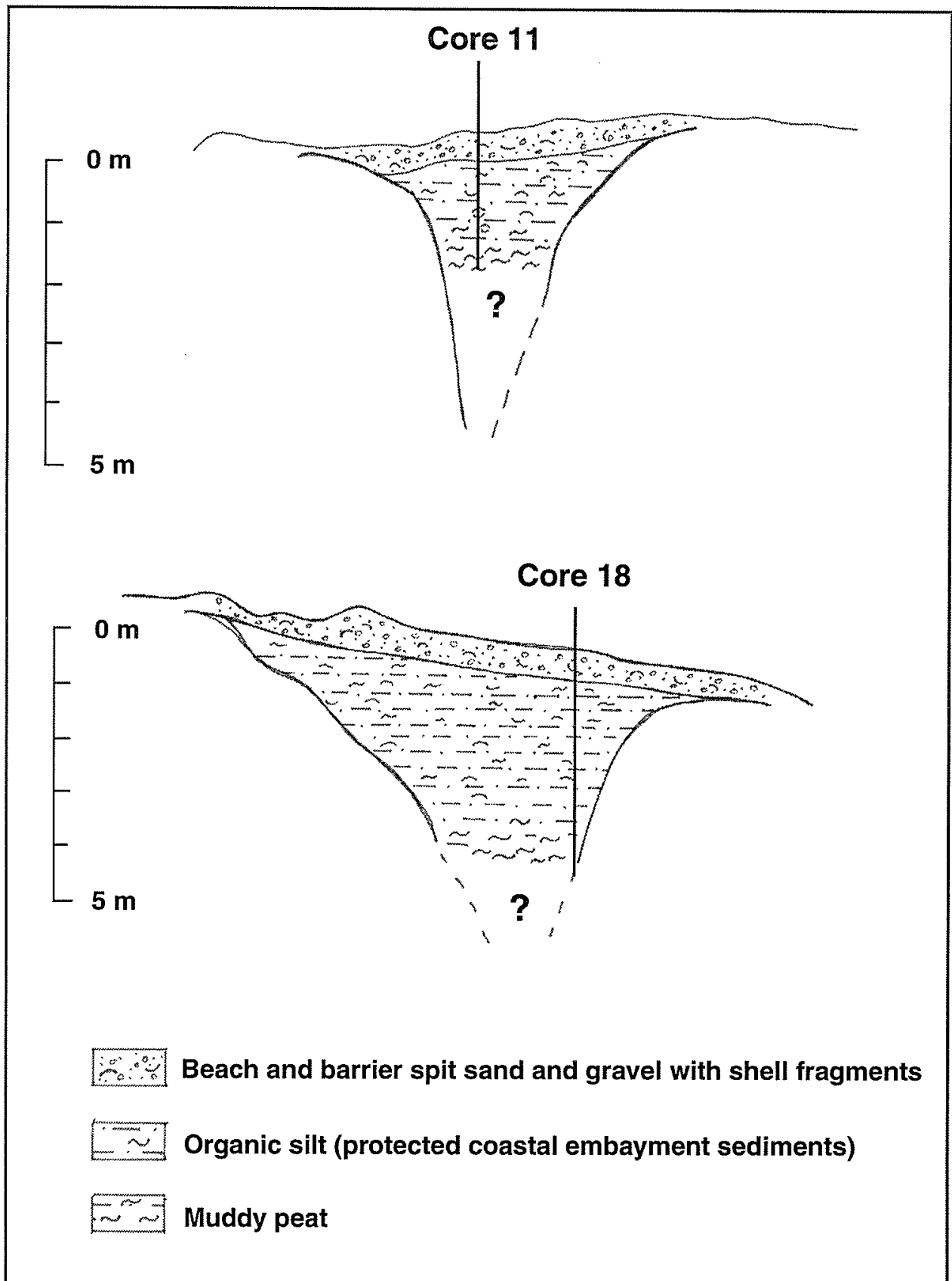

Figure 36. Cores and CHIRP profiles indicate that the sedimentary sequences in the two smaller channels on the western portion of the study site harbor transgressive sequences similar to those in Channels A, B, and C. These sequences lack the modern nearshore sand that were penetrated at the other core sites. Core 11 is from the channel imaged in survey line 3 and core 18 is from the channel profile in survey line 5. 


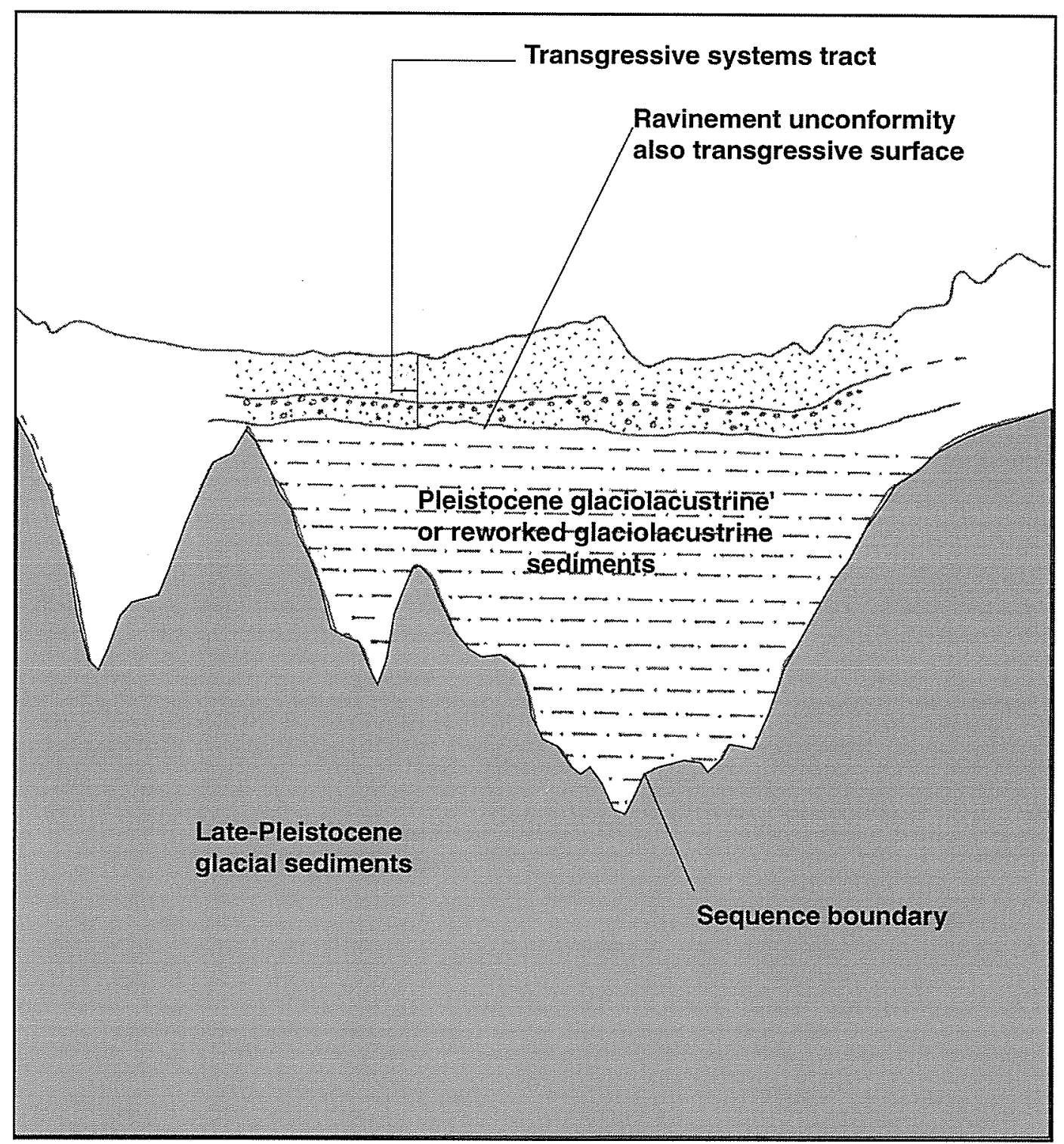

Figure 37. Sequence stratigraphic schematic of the channei-fill sequence occupying the Trunk Channel and Channel E. 


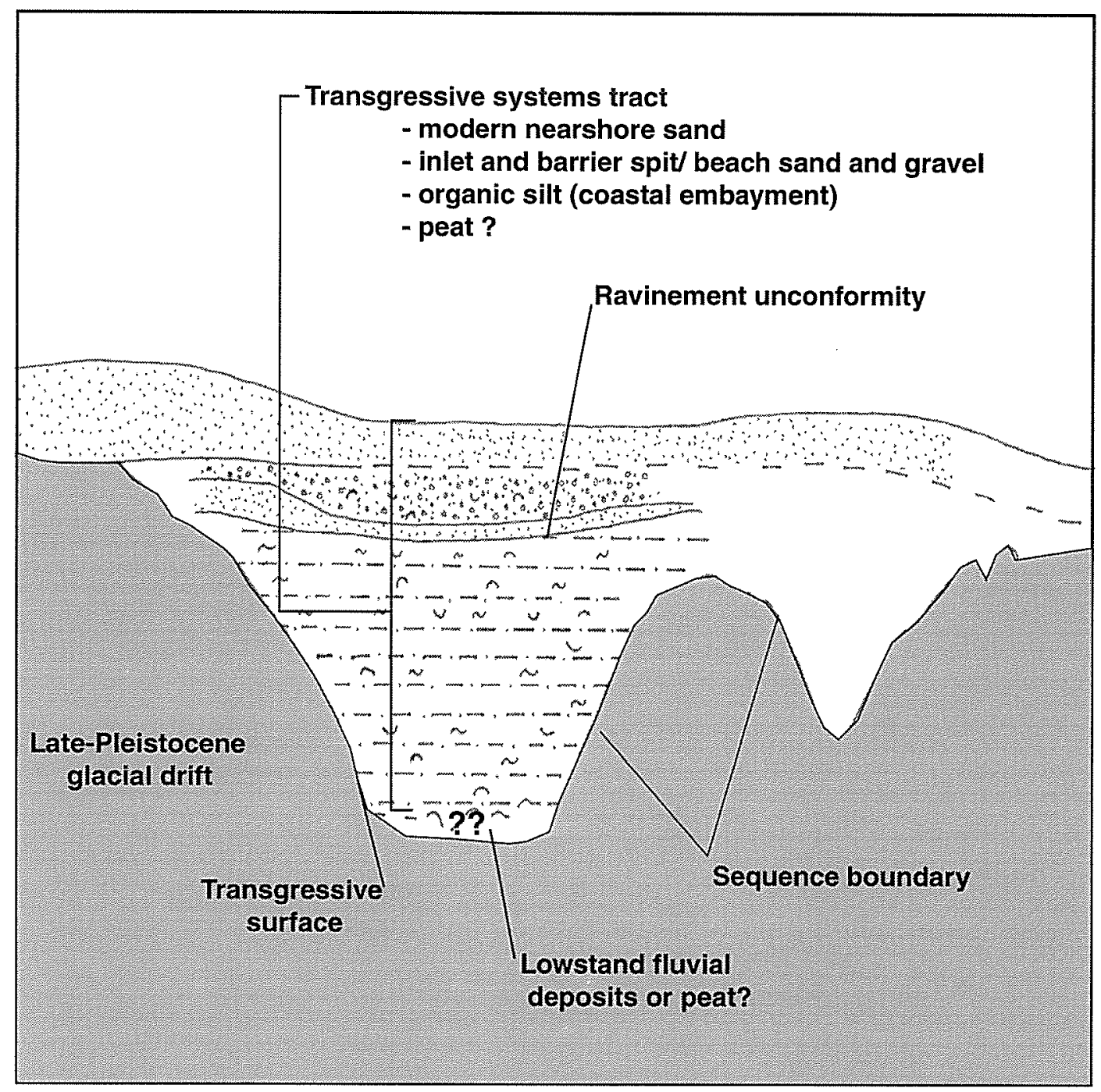

Figure 38. Diagram of the sequence architecture of the transgressive channel-fill sequences based on cores from Channels A, B, C and the two smaller channels coinciding with survey lines 3 and 5 the south shore of Cape Cod, Massachusetts. 


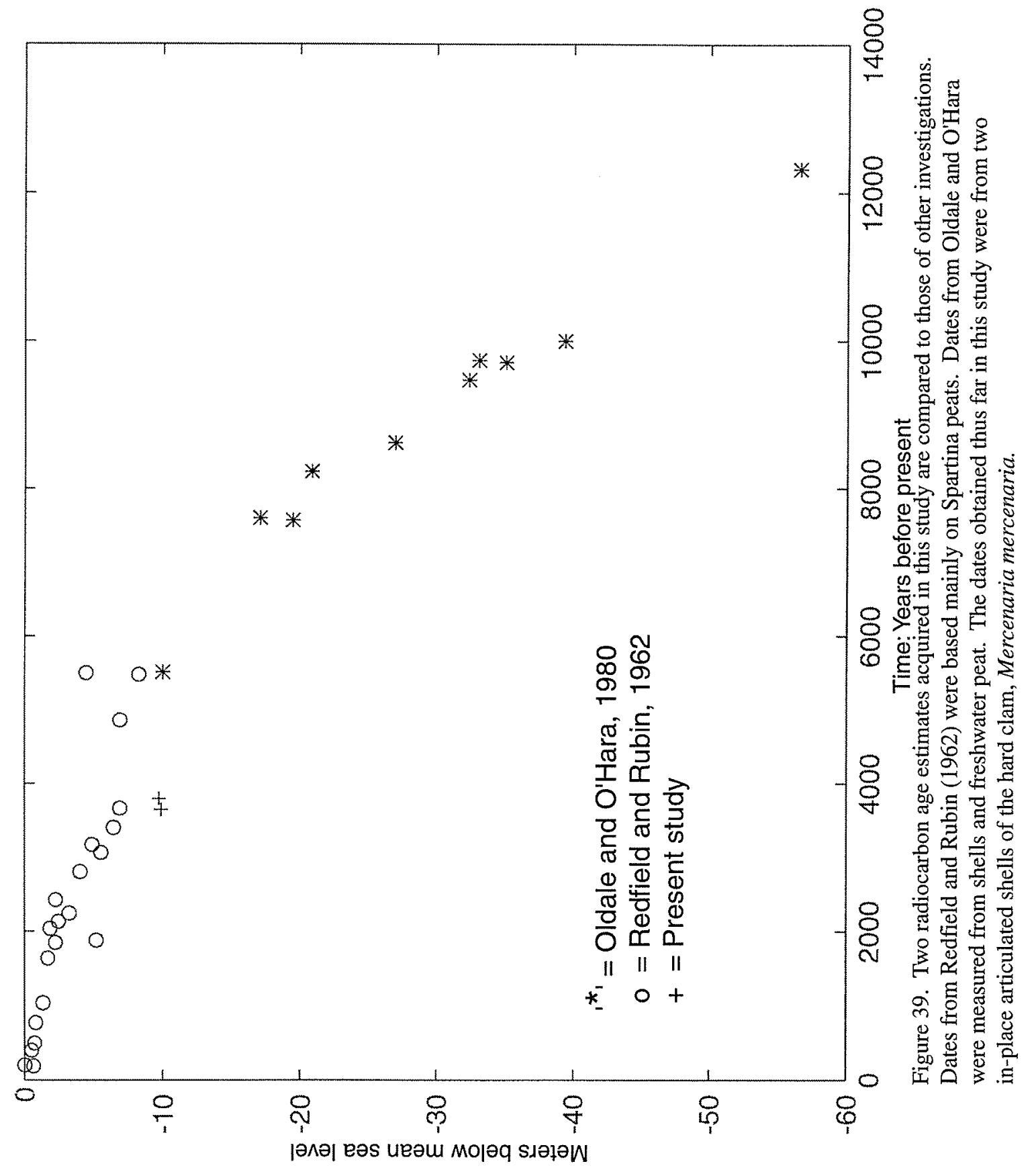




\section{TABLES}


Table 1. Core Locations

\begin{tabular}{|c|c|c|c|c|c|}
\hline Core \# & Latitude & Longitude & $\begin{array}{l}\text { Depth } \\
\text { (meters*) }\end{array}$ & $\begin{array}{l}\text { Recovered } \\
\text { Length }(\mathrm{m})\end{array}$ & Profile \# \\
\hline 1 & $41^{\circ} 35.054^{\prime}$ & $70^{\circ} 23.330^{\prime}$ & 9.3 & 1.57 & 42 \\
\hline 2 & $41^{\circ} 35.054^{\dagger}$ & $70^{\circ} 23.330^{\prime}$ & 9.3 & 2.67 & 42 \\
\hline 3 & $41^{\circ} 35.128^{\prime}$ & $70^{\circ} 23.364^{\prime}$ & 9.0 & 0.30 & 46 \\
\hline 4 & $41^{\circ} 34.454^{\prime}$ & $70^{\circ} 23.229^{\prime}$ & 8.2 & 3.95 & 45 \\
\hline 5 & $41^{\circ} 35.150^{\prime}$ & $70^{\circ} 23.265^{\prime}$ & 8.8 & 0.78 & 43 \\
\hline 6 & $41^{\circ} 35.150^{\prime}$ & $70^{\circ} 23.265^{\prime}$ & 8.8 & ---- & 43 \\
\hline 7 & $41^{\circ} 34.615^{\prime}$ & $70^{\circ} 23.553^{\prime}$ & 10.5 & 1.15 & 38 \\
\hline 8 & $41^{\circ} 34.608^{\prime}$ & $70^{\circ} 23.542^{\prime}$ & 10.5 & 0.90 & 38 \\
\hline 9 & $41^{\circ} 35.074^{\prime}$ & $70^{\circ} 23.340^{\prime}$ & 9.0 & 1.26 & 42 \\
\hline 10 & $41^{\circ} 35.160^{\prime}$ & $70^{\circ} 23.262^{\prime}$ & 8.8 & 1.99 & 43 \\
\hline 11 & $41^{\circ} 33.006^{\prime}$ & $70^{\circ} 27.693^{\prime}$ & 8.1 & 2.32 & 3 \\
\hline 12 & $41^{\circ} 35.262^{\prime}$ & $70^{\circ} 24.013^{\prime}$ & 7.0 & 1.83 & 39 \\
\hline 13 & $41^{\circ} 33.142^{\prime}$ & $70^{\circ} 25.619^{\prime}$ & 14.3 & 2.26 & 17 \\
\hline 14 & $41^{\circ} 33.200^{\prime}$ & $70^{\circ} 25.633^{\prime}$ & 14.6 & 1.99 & 17 \\
\hline 15 & $41^{\circ} 34.473^{\prime}$ & $70^{\circ} 24.642^{\prime}$ & 8.6 & 0.60 & 30 \\
\hline 16 & $41^{\circ} 34.473^{\prime}$ & $70^{\circ} 24.642^{\prime}$ & 8.6 & 1.48 & 30 \\
\hline 17 & $41^{\circ} 35.046^{\prime}$ & $70^{\circ} 23.300^{\prime}$ & 9.3 & 2.71 & 42 \\
\hline 18 & $41^{\circ} 33.446^{\prime}$ & $70^{\circ} 27.731^{\prime}$ & 7.8 & 4.87 & 5 \\
\hline 19 & $41^{\circ} 33.421^{\prime}$ & $70^{\circ} 27.256^{\prime}$ & 8.8 & 4.85 & 8 \\
\hline
\end{tabular}

* = Meters below present mean sea level as defined in this study.

Profile \# = Denotes the CHIRP survey lines corresponding to the sites where cores were acquired (See Fig. 22). 


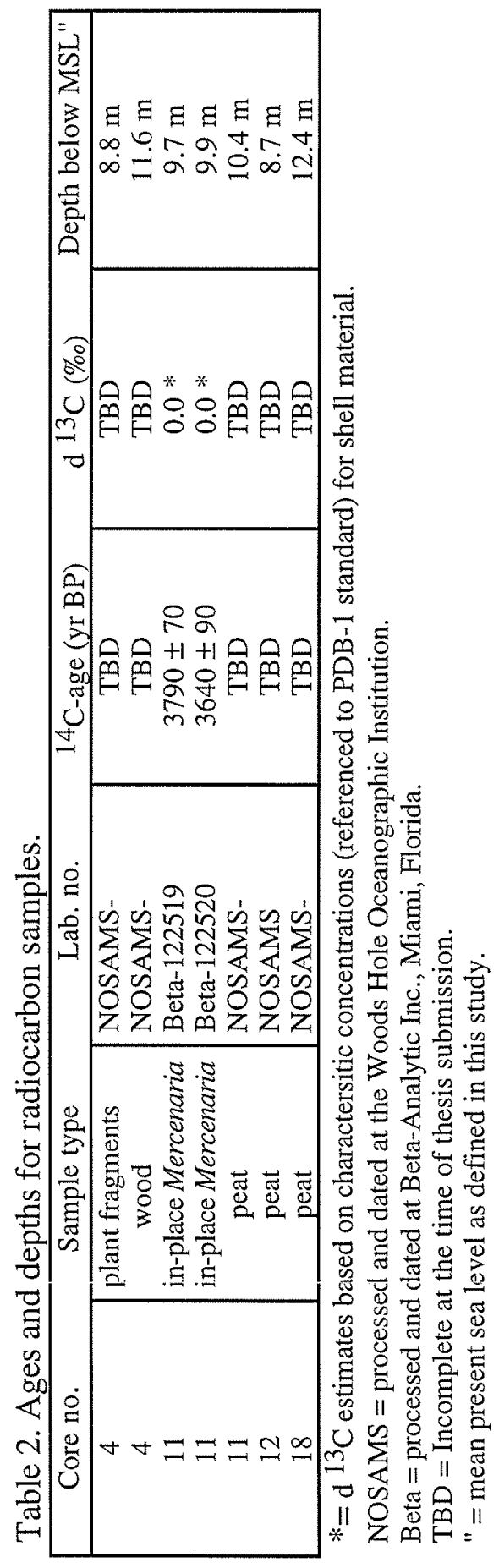


Table 3. Total organic carbon $(\% \mathrm{C})$ and nitrogen $(\% \mathrm{~N})$ concentrations for core samples.

\begin{tabular}{|c|c|c|c|c|c|}
\hline core \# & \multicolumn{1}{c}{ depth $(\mathrm{m})^{*}$} & \multicolumn{1}{c}{ sample type } & \multicolumn{1}{c|}{ \% } & \multicolumn{1}{c|}{ N } & C/N \\
\hline 4 & 8.7 & organic mud & 2.9 & 0.9 & 2.3 \\
4 & 9.9 & organic mud & 4.4 & 2.2 & 2.4 \\
11 & 10.3 & muddy peat & 5.9 & 1.3 & 5.6 \\
12 & 7.5 & organic mud & 3.6 & 1.4 & 3.1 \\
12 & 8.5 & peat & 10.6 & 1.7 & 7.1 \\
13 & 15.1 & silt & 0.9 & 0.9 & 1.2 \\
13 & 16.3 & silt & 1.2 & 1.0 & 1.4 \\
14 & 15.2 & silt & 1.1 & 1.1 & 1.2 \\
14 & 16.3 & silt & 1.7 & 1.5 & 1.3 \\
17 & 10.6 & organic mud & 1.9 & 1.0 & 2.2 \\
17 & 11.8 & organic mud & 2.1 & 1.3 & 1.9 \\
18 & 9.3 & organic mud & 3.7 & 1.8 & 2.3 \\
18 & 12.1 & muddy peat & 5.5 & 1.3 & 5.1 \\
19 & 9.9 & silt & 0.7 & 0.6 & 1.3 \\
19 & 10.5 & silt & 0.7 & 0.8 & 0.9 \\
19 & 11.8 & silt & 1.4 & 1.7 & 1.0 \\
\hline
\end{tabular}

$*=$ meters below present mean sea level defined in this study. 